The University of Maine

DigitalCommons@UMaine

Electronic Theses and Dissertations

Fogler Library

Summer 8-15-2015

\title{
Linking Attitudes, Policy, and Forest Cover Change in Buffer Zone Communities of Chitwan National Park, Nepal
}

Jared R. Stapp

University of Maine - Main, stappjared@gmail.com

Follow this and additional works at: http://digitalcommons.library.umaine.edu/etd

Part of the Environmental Studies Commons

\section{Recommended Citation}

Stapp, Jared R., "Linking Attitudes, Policy, and Forest Cover Change in Buffer Zone Communities of Chitwan National Park, Nepal" (2015). Electronic Theses and Dissertations. 2253.

http://digitalcommons.library.umaine.edu/etd/2253

This Open-Access Thesis is brought to you for free and open access by DigitalCommons@UMaine. It has been accepted for inclusion in Electronic

Theses and Dissertations by an authorized administrator of DigitalCommons@UMaine. 


\title{
LINKING ATTITUDES, POLICY, AND FOREST COVER CHANGE IN BUFFER ZONE COMMUNITIES OF CHITWAN NATIONAL PARK, NEPAL
}

\author{
By \\ Jared Richard Stapp \\ B.S. Utah State University, 2012 \\ A THESIS \\ Submitted in Partial Fulfillment of the \\ Requirements for the Degree of \\ Master of Science \\ (in Ecology and Environmental Sciences) \\ The Graduate School \\ University of Maine
}

August 2015

Advisory Committee:

Robert J. Lilieholm, School of Forest Resources, Co-Advisor

Christopher S. Cronan, School of Biology and Ecology, Co-Advisor

Jessica Leahy, School of Forest Resources

Timothy Waring, School of Economics 


\section{THESIS ACCEPTANCE STATEMENT}

On behalf of the Graduate Committee for Jared R. Stapp we affirm that this manuscript is the final and accepted thesis. Signatures of all committee members are on file with the Graduate School at the University of Maine, 42 Stodder Hall, Orono, Maine.

Dr. Robert J. Lilieholm, E.L. Giddings Professor of Forest Policy

Date

Dr. Christopher S. Cronan, School of Biology and Ecology Date 


\section{LIBRARY RIGHTS STATEMENT}

In presenting this thesis in partial fulfillment of the requirements for an advanced degree at The University of Maine, I agree that the Library shall make it freely available for inspection. I further agree that permission for "fair use" copying of this thesis for scholarly purposes may be granted by the Librarian. It is understood that any copying or publication of this thesis for financial gain shall not be allowed without my written permission.

Jared R. Stapp

Date 


\title{
LINKING ATTITUDES, POLICY, AND FOREST COVER CHANGE IN BUFFER ZONE COMMUNITIES OF CHITWAN NATIONAL PARK, NEPAL
}

\author{
By Jared Richard Stapp
}

Thesis Co-Advisors: Dr. Robert J. Lilieholm \& Dr. Christopher S. Cronan

\author{
An Abstract of the Thesis Presented \\ in Partial Fulfillment of the Requirements for the \\ Degree of Master of Science \\ (in Ecology and Environmental Sciences)
}

August 2015

Deforestation in Nepal threatens the functioning of complex social-ecological systems, including rural populations that depend on forests for subsistence, as well as Nepal's biodiversity and other ecosystem services. Reliance on forest resources, coupled with high population densities and rates of growth, highlights the importance of studying the relationship between human communities, forest cover and trends through time, and forest management institutions. A Master Plan for Nepal’s Forestry Sector (MPFS), enacted in 1989, laid the foundation for modern community-based forest management in Nepal. In 2014, the MPFS reached the end of its 25-year lifespan, after successfully ushering in significant institutional changes that fundamentally transformed the management of Nepal's forests, mostly through devolving management and benefits from the national level to local communities. 
Here, we examine the effectiveness of the MPFS to offer insight into this complex coupled human and natural system. Using remote sensing techniques and Landsat satellite imagery, the 25-year anniversary of the MPFS was used to explore forest cover trends in the buffer zone Village Development Committees surrounding Chitwan National Park (CNP). An in-country household survey was then conducted to: (1) understand how local attitudes toward forest conservation-related behaviors correlated with empirical forest cover trends; and (2) understand which socio-demographic variables influenced supportive attitudes. The survey was conducted in two rural communities in southern Nepal—one that has experienced significant forest loss, the other forest gain— compare with forest cover trends as indicated by the results from Chapter 1. Lastly, we used an agent-based model (ABM) to explore what effect village attitudes toward forest conservation would have on the extent of forest cover if improved policies are implemented, population growth rate fluctuates, and villages are able to cooperate by mimicking each other's attitudes and behaviors.

Results suggest that since the MPFS was enacted, there was first a continued decrease in forest cover, followed by a significant increase overall. Survey results suggest a significant difference in attitudes toward forest conservation in the two areas studied, and in both study sites, participation in community forestry strengthened support for conservation, supportive forest conservation-related attitudes aligned with forest cover gain in recent years, and a negative relationship was found between economic status and having supportive attitudes. Additionally, on average, respondents did not feel that the current national political climate in Nepal supported sustainable forestry. The results from the ABM suggest that improving forest-related policies would have a dramatic 
effect on the forest cover over time, the ability for villages to cooperate will likely have little effect on forest cover, and population growth rate will likely have a significant effect on forest extent. We also found that despite clear strengths, there are challenges with using ABM to model forest conservation dynamics and land use/land cover change at different scales. These data offer insight into the success of modern community-based forest management policies and supporting institutions, and are especially important as Nepal's Master Plan for the Forestry Sector has expired and the country is in the process of structuring a new Forestry Sector Strategy. 


\section{DEDICATION}

This thesis is dedicated to the people living in the buffer zone of Chitwan National Park, Nepal. Never have I experienced such kindness, warmth, and generosity as I did while conducting the field work for this project. Despite the 110 degree heat, countless motorcycle rides on undeveloped, muddy roads with more elephants than cars, and a constant language barrier, I was greeted in every village with hibiscus flowers, smiles, and a genuine willingness to help me in any way I needed—viewing me as young, curious student, eager to learn more about how they live their lives in a place so different than my own home. The underlying motive for this work has been to not just shed light on the benefits and functionality of decentralized community-based natural resource management, but to highlight areas—-through listening to people's concerns and experiencing their livelihoods first-hand—where the system can be improved to better meet their everyday needs. I anticipate the day when I can return to Nepal and share this work in its completion with the people I have worked with over a strong pot of Nepali tea. 


\section{ACKNOWLEDGEMENTS}

My time as an M.S. student has helped me improve in all aspects of being a good scientist, and I attribute this to the people I have worked with at UMaine. My adviser, Dr. Rob Lilieholm, has been my biggest supporter along the way. Rob has always patiently helped me whenever I was having difficulty and encouraged me to push myself, take advantage of every opportunity available to me, and to pursue the ideas I am genuinely interested in. There has never been an instance when he wasn't readily available as a mentor to me, and I am very grateful for the experiences I have had while working alongside him—from floating the crocodile-filled Rapti river in a tipsy dugout canoe, to spotting One-horned rhinos while riding elephants in Chitwan, to drinking beers on rooftops in Kathmandu, to reminiscing about our shared appreciation for the simplicity of the Utah desert. I look forward to working closely with Rob throughout my research career, and wish him and his family all the best in their upcoming transitions.

My other committee members, Drs. Jessica Leahy, Tim Waring, and Chris Cronan, have all been immensely helpful in the last two years as well. I took Jessica's Rural Communities course during my first semester at UMaine, and it is perhaps my favorite classroom experience I have had in my M.S. I have great admiration for the critical and thoughtful way Jessica thinks about and studies human dimensions of natural resource management—such as poverty, social capital, diversity, and resource dependence-which is evident in the following manuscript. She has continually helped me beyond the typical obligations of a graduate committee member, and I am grateful for her time, honest feedback, and caring advice. Among other components, the success of our household survey and the statistical methods used in its analysis are largely due to her 
expertise. Tim has gone above and beyond in helping me since I have been at UMaine as well, and since working with him, my understanding of complexity theory, human behavior and decision making, and the ways in which social systems evolve, have grown dramatically. Before beginning my M.S., I had never used agent-based modeling, or any type of modeling beyond basic statistics, and I have gained a vast appreciation for the discipline. As I continue my career, I look forward to working with both Jessica and Tim, and learning all that I can from them.

I am grateful for my colleagues and close friends, Gretchen Huff, Kristen Weil, David Carter, Emily Silver, Suraj Upadhaya, and Stephanie Tomlin. All of them have contributed greatly to my academic and personal lives in the last two years in more ways than they know, from helping me with my thesis work, adventuring in the Maine woods, giving me advice when I needed it, to getting beers after long nights in front of a computer. These ambitious folks inspire me daily, and I am glad I have been fortunate enough to work and adventure alongside them all.

I owe many thanks to the institutions and generous individuals who helped me while in Nepal—-the World Wildlife Fund-Nepal, the Federation of Community Forestry Users Nepal, Kathmandu Forestry College, Pokhara Institute of Forestry, the Department of National Parks and Wildlife Conservation of Nepal, Abdul Ansari, Baburam Vishowkarma, Satya-Narayan Chaudhary, Yubaraj Ghatane, Beeju Poudyal, and Dr. Ambika Gautam. Additionally, Carol Kinsey, executive director of the NGO SeedTree, has been amazingly helpful to me. She is truly an inspiration to me, and I aspire to make the world a better place in ways that she has in her career and personal life. Thank you also to Tika's beautiful family at the Gaida Lodge for giving me a home while in Nepal. 
I thank the Oblock family for their love and support throughout my formative years in Utah. They were perhaps the first in my life to encourage me to be ambitious in my academic and career goals, and pursue what I love.

The first chapter of this thesis was accepted as a journal manuscript by the Journal of Sustainable Forestry on February 27, 2015. Tora Johnson, a Ph.D. student in the Ecology and Environmental Sciences Program and coauthor on the manuscript, was incredibly helpful in writing tasks and developing the remote sensing methodology for this chapter. Thank you also to Suraj Upadhaya (coauthor as well), Amy Dowley, and Cynthia Loftin, for their assistance in working with remote sensing methods and Landsat 8 data, as well as the USGS for making satellite images available to the public. The historic aerial photos were provided by Dr. Chudamani Joshi, who originally obtained them from the Department of Forest Research and Survey, Nepal. This analysis would have not been possible without their assistance.

The second chapter was submitted to Environmental Management on December 19, 2014, and was returned with comments from the editor on January 3, 2015, requesting resubmission following minor changes to the Discussion section. The journal manuscript has been thoroughly revised (see Chapter 2), and was resubmitted to Environmental Management on June 11th. The manuscript is under review. Rob Lilieholm, Jessica Leahy and Suraj Upadhaya are coauthors on the manuscript and were all immensely helpful in designing the survey, arranging for it to be carried out in Nepal, and conducting the analysis.

Chapter three, as it is presented here, is not formatted as a journal manuscript. During the summer of 2015, the chapter was re-written as a journal manuscript to be 
submitted as an 'Insight' article to Ecology and Society. Since writing has been completed, our goal is to submit the manuscript on July $20^{\text {th }}$, 2015. I thank Rob Lilieholm, Tim Waring, Jessica Leahy, and Emily Silver for their help with this chapter. Funding for this project was supported by the National Science Foundation award EPS-0904155 to Maine EPSCoR Sustainability Solutions Initiative at the University of Maine, McIntire-Stennis grant number MEO-M-700510-13, and the USDA National Institute of Food and Agriculture. Additional support was provided by the Maine Agriculture and Forestry Experimental Station (Publication numbers 3404 \& 3405) and the Center for Research on Sustainable Forests. 


\section{TABLE OF CONTENTS}

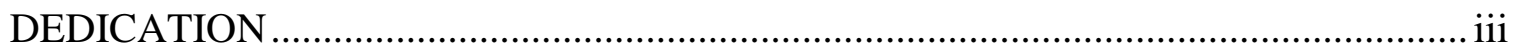

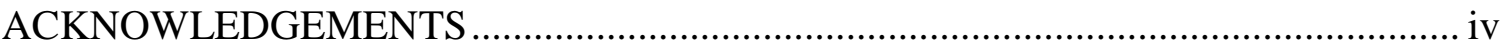

LIST OF TABLES

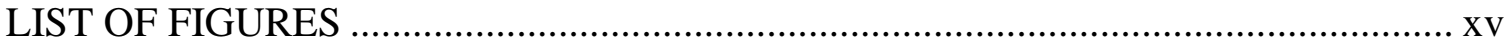

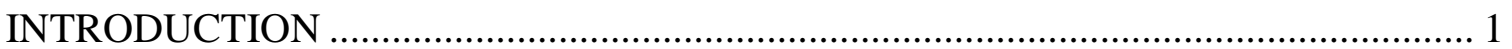

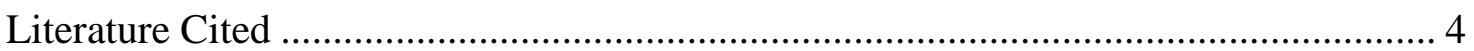

CHAPTER 1 EVALUATING THE IMPACTS OF FOREST MANAGEMENT

POLICIES AND COMMUNITY-LEVEL INSTITUTIONS IN THE BUFFER

ZONE OF CHITWAN NATIONAL PARK, NEPAL …………………........................ 8

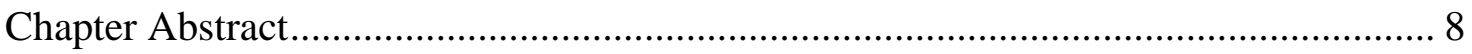

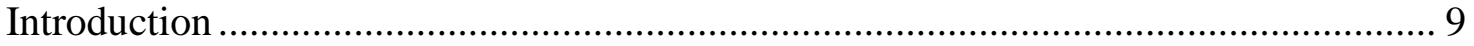

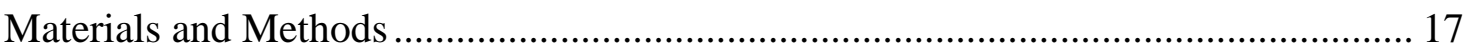

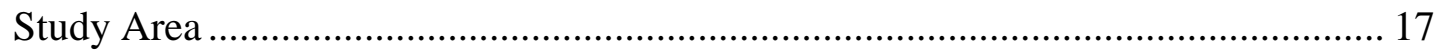

Data Used and Data Analysis ................................................................................ 19

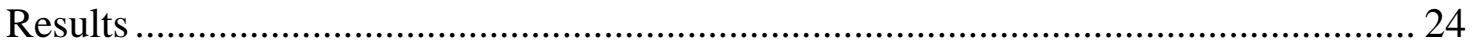

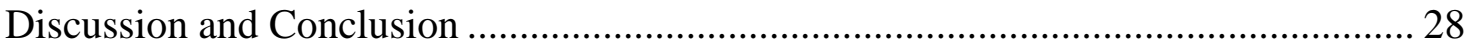

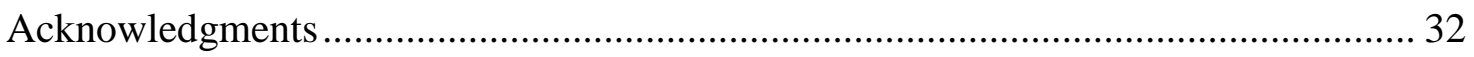

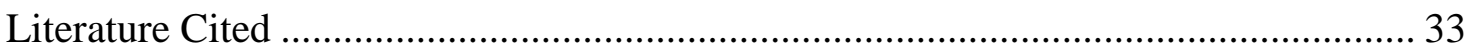




\section{CHAPTER 2 LINKING ATTITUDES, POLICY, AND FOREST COVER}

CHANGE IN BUFFER ZONE COMMUNITIES OF CHITWAN NATIONAL

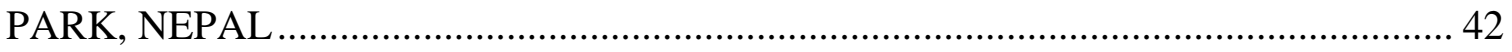

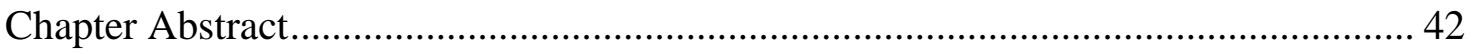

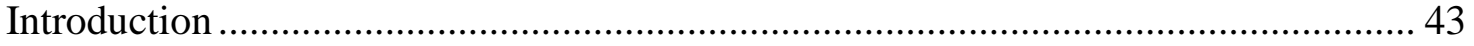

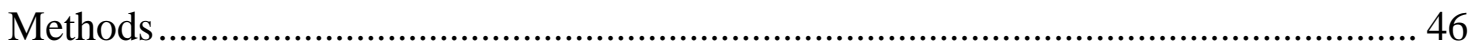

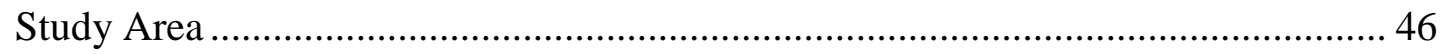

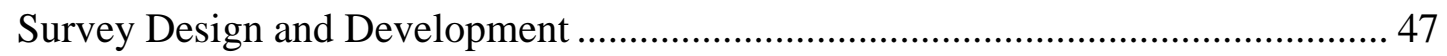

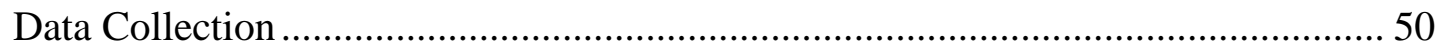

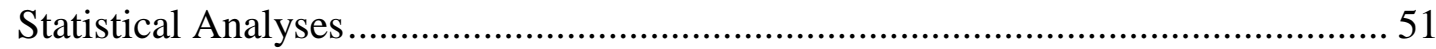

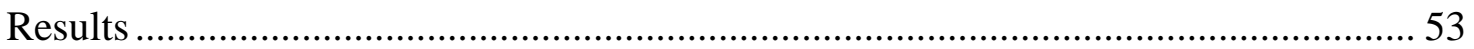

Socio-Demographic Characteristics of Respondents ........................................... 53

Distribution and Difference in Attitudes Between Bachauli and Narayani............... 55

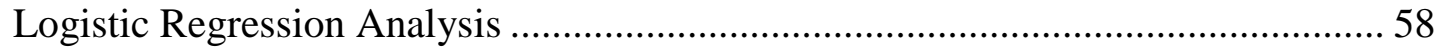

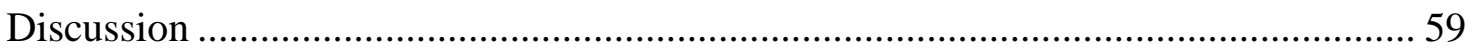

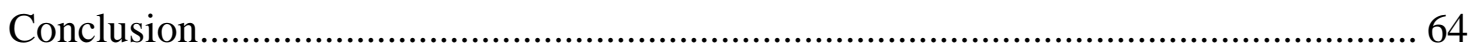

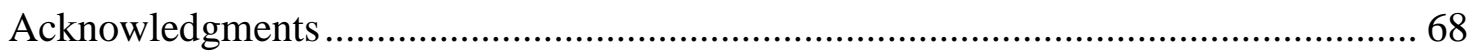

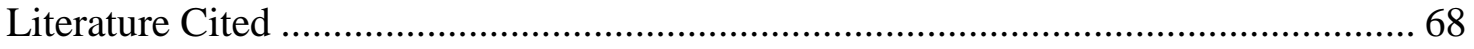


CHAPTER 3 USING AGENT-BASED MODELING TO EXAMINE VILLAGE-

LEVEL LAND USE/LAND COVER CHANGE DECISION-MAKING:

A FOREST CONSERVATION CASE STUDY IN BACHAULI, NEPAL .................... 79

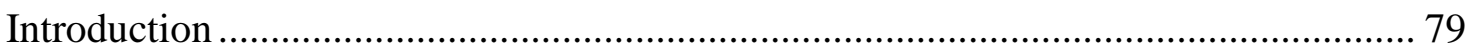

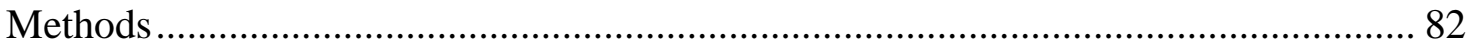

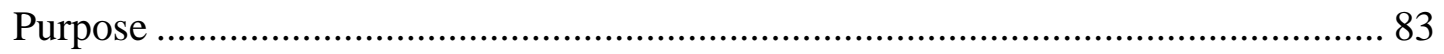

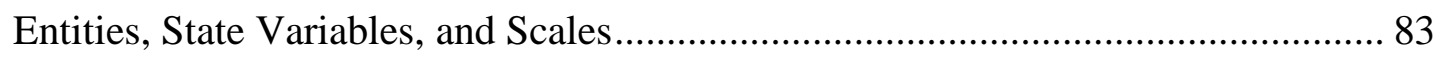

Process Overview and Scheduling ..................................................................... 86

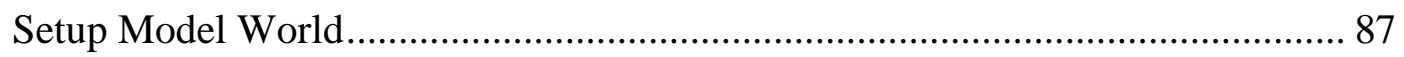

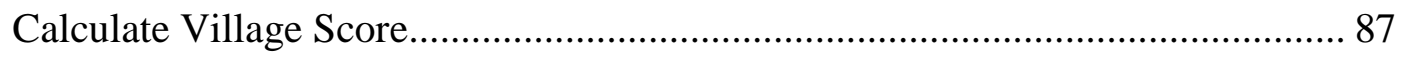

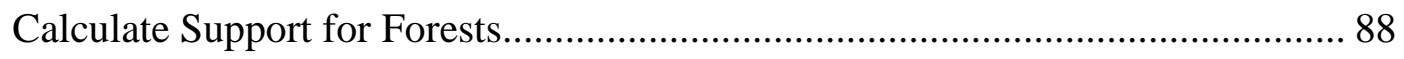

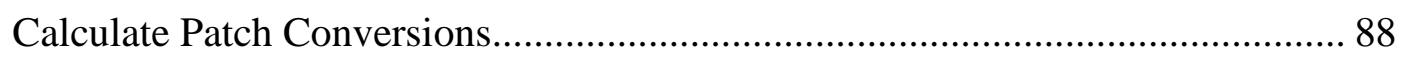

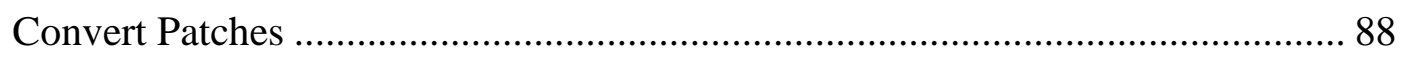

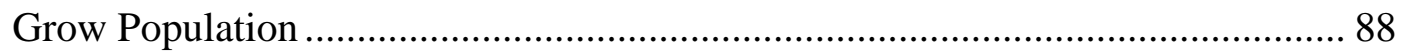

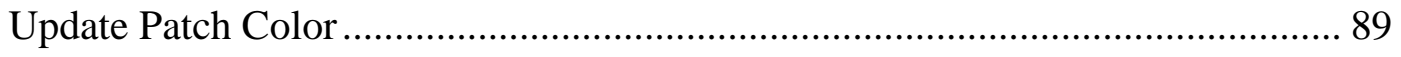

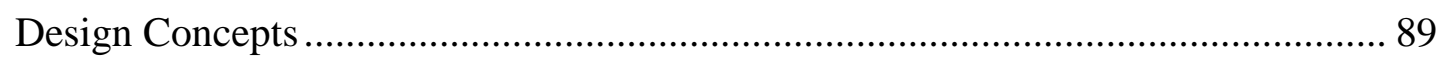

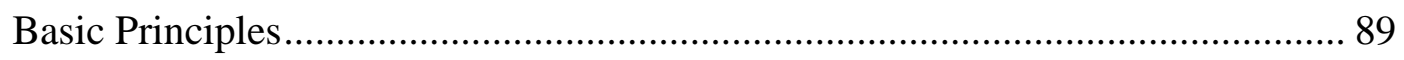

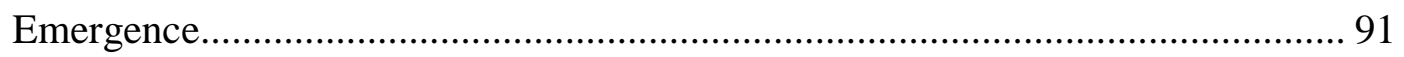

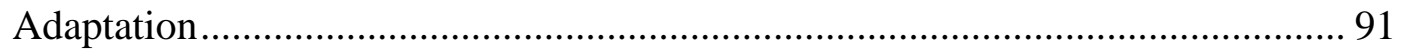

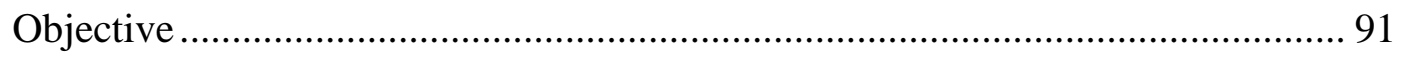


Learning

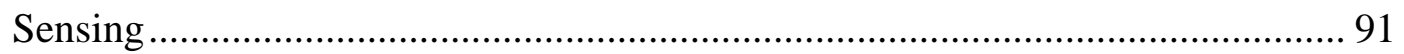

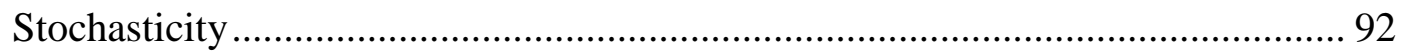

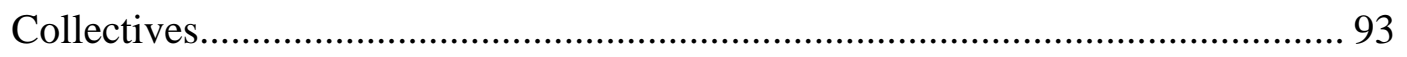

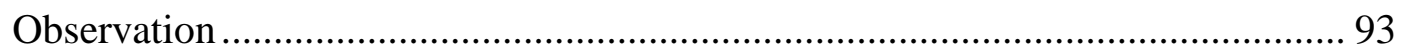

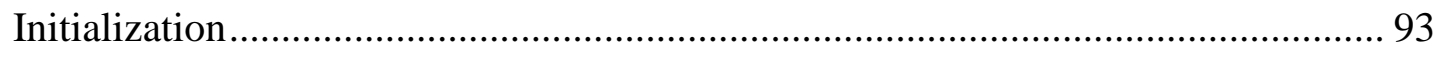

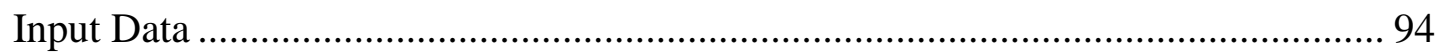

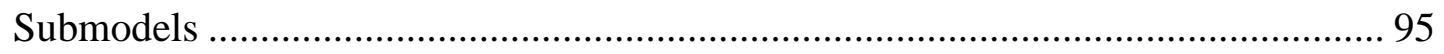

Gis Extension Data and World Setup ............................................................ 95

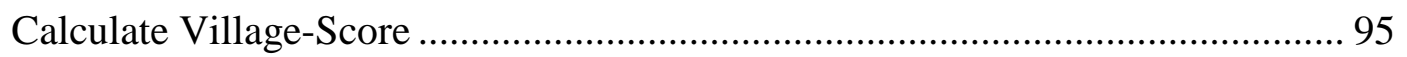

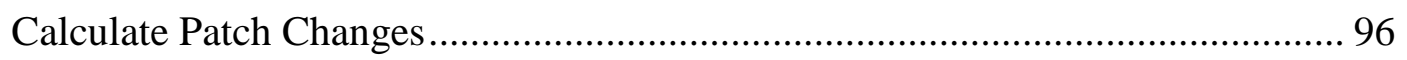

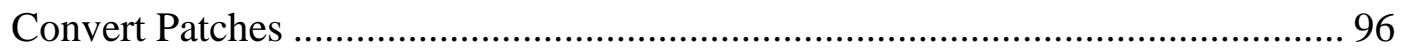

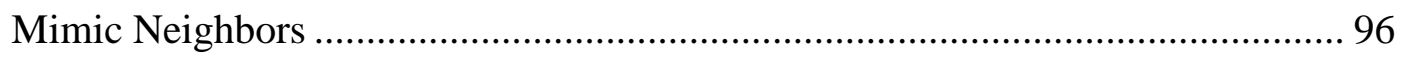

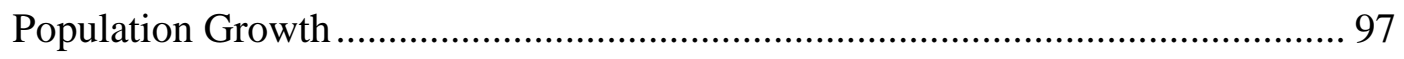

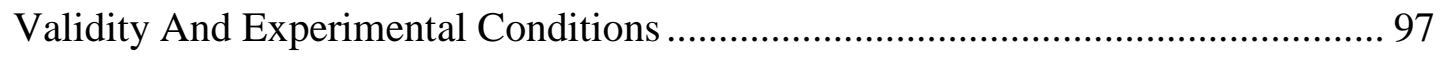

Simulation Experiments/Model Analysis ...................................................... 97

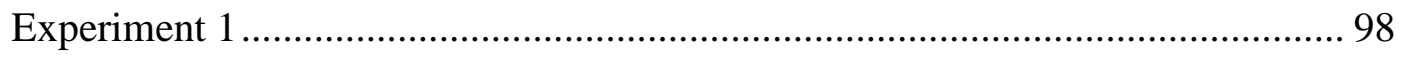

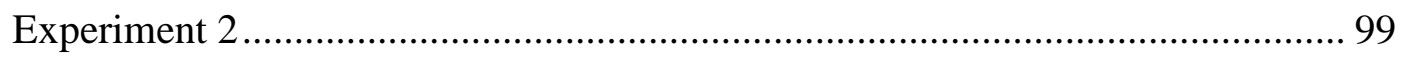

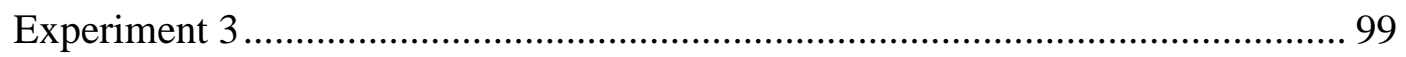

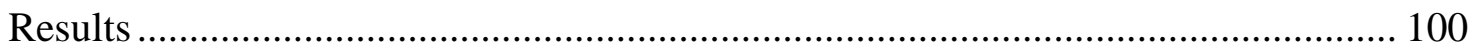




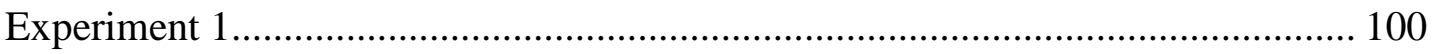

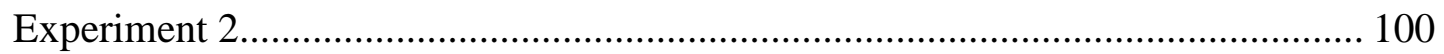

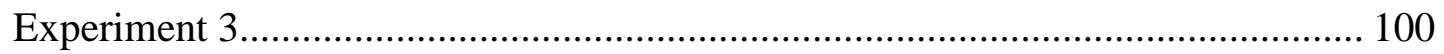

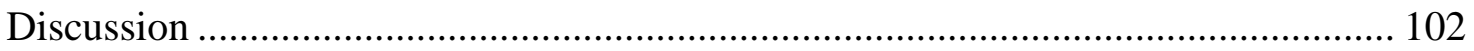

Data Availability and Parameter Inclusion in Developing Nations Such

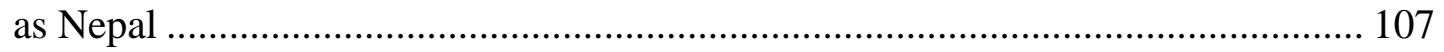

Challenges With Using Social Surveys in ABM................................................. 109

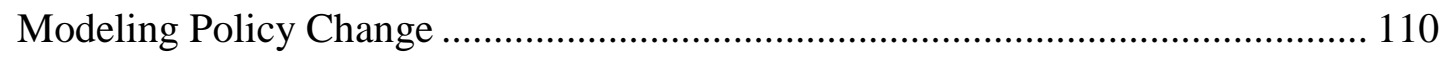

Heterogeneity at Different Scales............................................................... 112

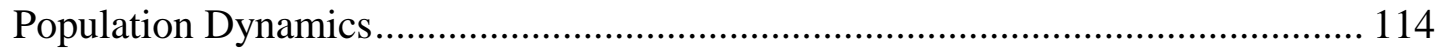

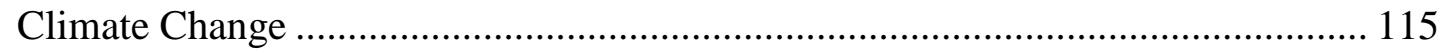

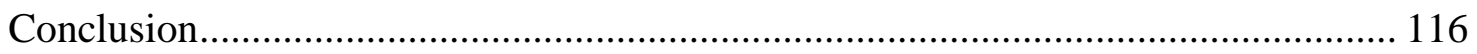

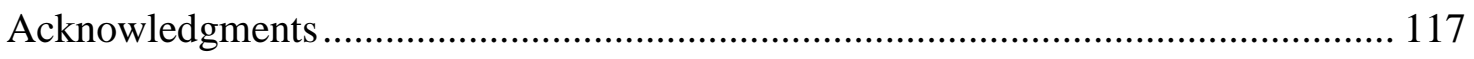

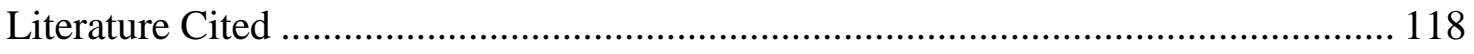

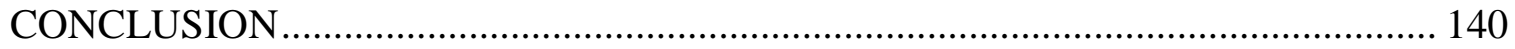

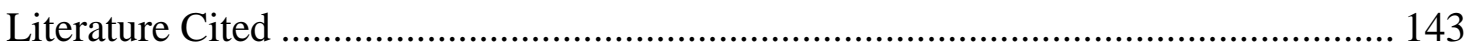

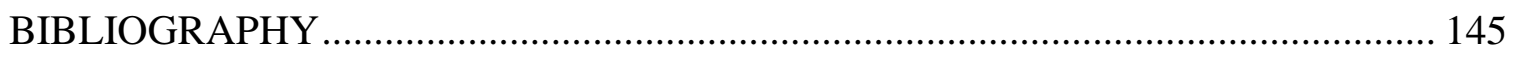

APPENDIX A: INSTITUTIONAL REVIEW BOARD DECISION LETTER ............. 164

APPENDIX B: SURVEY CONDUCTED IN NEPAL

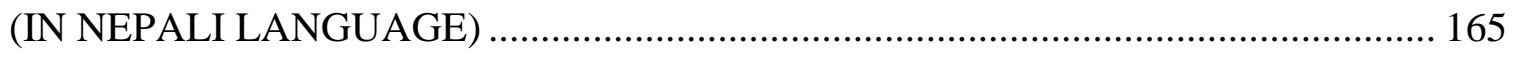


APPENDIX C: SURVEY CONDUCTED IN NEPAL

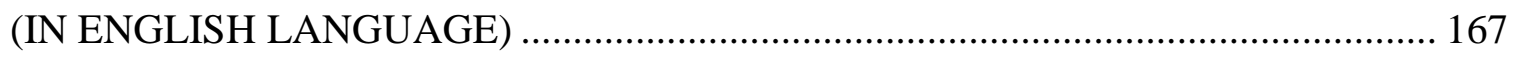

APPENDIX D: FULL, DOCUMENTED AGENT-BASED MODEL CODE................ 169

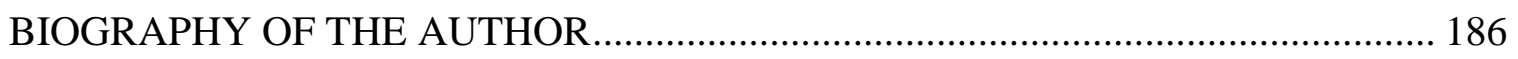




\section{LIST OF TABLES}

Table 1.1. Remote sensing and GIS data used for NDVI analysis. ..............................21

Table 1.2. Accuracy assessment for NDVI reclassification. ........................................23

Table 1.3. Forest change between 1989, 2005, and 2013 based on NDVI analysis ..........25

Table 2.1. Distribution of responses to all survey questions in

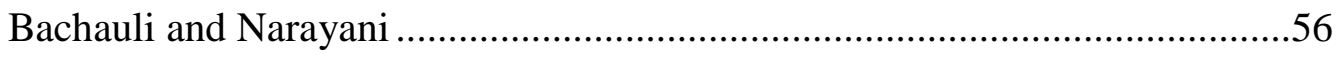

Table 2.2. Mean survey responses and t-test results for Bachauli and Narayani...............57

Table 2.3. Logistic regression examining correlation between sociodemographic variables and positive attitudes toward forest conservationrelated behavior in Bachauli. ${ }^{\text {a }}$

Table 2.4. Logistic regression examining correlation between socio-demographic variables and negative attitudes toward forest conservation-related behavior in Narayani. ${ }^{\text {a }}$

Table 3.1. Descriptions of all agent and patch variables in the model. ...........................84

Table 3.2. Descriptions of all global and local variables in the model...........................85

Table 3.3. Base values given to variables upon initialization.......................................94

Table 3.4. Treatment conditions for each experiment. ...............................................98

Table D.1. Full, documented code for agent-based model presented in Chapter 3.........169 


\section{LIST OF FIGURES}

Figure 1.1. Terai region of Nepal, Chitwan National Park, and the 36 village development committees (VDCs) in the buffer zone.

Figure 1.2. Forest cover in the buffer zone of Chitwan National Park (CNP) in 1989,2005 , and 2013

Figure 1.3. Forest cover change in the buffer zone of Chitwan National Park (CNP) between 1989-2005 and 2005-2013. .28

Figure 2.1. Location of Chitwan National Park and the VDCs of

Bachauli and Narayani. .48

Figure 3.1. Location and NetLogo model image showing land cover of Bachauli upon Setup. .86

Figure 3.2. Flow chart of model variables and processes. Variables may positively and/or negatively affect other variables as indicated by plus and minus symbols. .90

Figure 3.3. Mean percent forest cover and standard error between 2015 and 2040 for all nine treatments, for all 50 model runs.

Figure 3.4. Boxplots for percent forest cover for the year 2040 for all nine treatments $(\mathrm{T}=$ treatment), for all 50 model runs of each treatment.

Figure 3.5. Art as metaphors for the varied modeling approaches: (A) Detailed Realism; (B) Apparent Realism; (C) Statistical Realism; (D) Essential Realism (modified from Dietrich et al., 2003). .106

Figure A.1. University Of Maine Institutional Review Board decision letter (Application \#2014-02-14) .164 


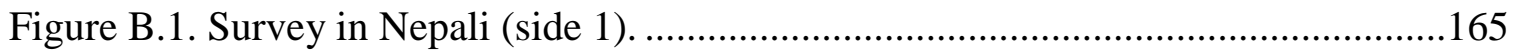

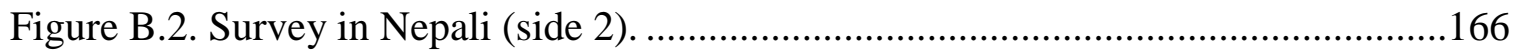

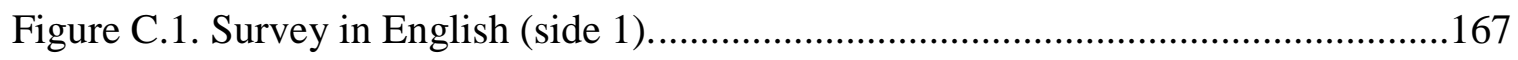

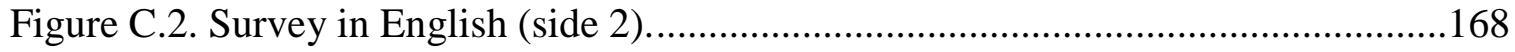




\section{INTRODUCTION}

After decades of deforestation in the latter part of the $20^{\text {th }}$ Century, Nepal is now regarded by some as one of the world's leading examples of successful community-based forest management (Gautam et al., 2004). Nepal was one of the earliest adopters of community forestry in Asia (Pandit \& Bevilacqua, 2011 citing Arnold, 1992), and modern community-based forest management grew from a Master Plan for the Forestry Sector (MPFS) enacted in 1989, followed by related legislation in 1993 and 1995 (HMGN, 1993, 1995; HMGN, ADB, \& FINNIDA, 1988). In combination, the core goal of these three pieces of legislation was to grant limited management rights and authority to established community user groups to rehabilitate degraded forest parcels in order to better meet the needs of local people. Community Forest User Groups (CFUGs) and Buffer Zone Community Forest User Groups (BZCFUGs; from here forward, 'CFUGs' will be used interchangeably) were granted limited authority to manage forests in their communities.

Modern community forestry in Nepal, however, began only after a long history of political instability and rigid and hierarchical centralized forest management institutions. During the mid-20 ${ }^{\text {th }}$ Century, the lowland forests of southern Nepal were rapidly cleared in response to national policies promoting timber harvest, agricultural expansion, and malaria eradication (Schweik et al., 2003). The eradication of malaria in the south, along with the construction of improved road systems, increased migration into the Terai, development, and intensified commercial forestry. Increasing settlements made agriculture more important in the region, as the Terai is known as the fertile bread basket 
of Nepal. And, increased clearing for agriculture made more land available for migrants from less-productive regions of the country (Pravat, 2006).

Today, forests cover approximately $25.4 \%$ of the country (World Bank, 2013) and there are 1.7 million ha of community forest—about $29 \%$ of all forests in Nepal and supporting approximately 2.25 million households (GoN, 2014). Although community forestry has been highly influential in Nepal, there have been varying levels of success among communities in the last 25 years in terms of reversing historic deforestation trends, granting representation to various socio-demographic and ethnic groups, providing local employment, and promoting efficient bureaucratic structures (GoN, 2014). A growing body of evidence—-both empirical and anecdotal—suggests that modern forest-related policy changes have been effective in decentralizing management and reducing rates of forest loss (GoN, 2014), and some studies suggest that communitybased forest management has been effective in combatting forest degradation in Nepal over the last 25 years (Gautam, 2007; GoN, 2014; Nagendra, 2007; Nepal \& Spiteri, 2011; Spiteri \& Nepal, 2008; Stræde \& Treue, 2006).

The following three chapters incorporate different methodologies to examine the effectiveness of the MPFS and community-based forest management, and to offer insight into this complex coupled human and natural system. Chapter 1 uses remote-sensing techniques to examine trends in forest loss and gain over the last 25 years, and sets these trends within the context of the emergence of community-based management and modern forestry policies in the buffer zone of Chitwan National Park (CNP). Remote sensing and GIS techniques have been widely used to analyze forest cover dynamics in Nepal since the establishment of modern forestry legislation (see e.g., Jackson et al., 1998; Schreier et 
al., 1994; Virgo and Subba, 1994; Panta et al., 2008), and have been found to provide a spatio-temporal perspective when analyzing the relative success of forest management policies (Nagendra et al., 2004).

Chapter 2 describes the results of a household survey in two Village Development Committees (VDCs) located adjacent to CNP. The VDCs were purposively selected based on the results from Chapter 1, which identified buffer zone communities experiencing high levels of forest loss and regeneration between 2005 and 2013. Chapter 2 had two objectives. First, we sought to understand how household attitudes toward forest conservation-related behaviors correlated with empirical forest cover trends. Second, we were interested in which socio-demographic variables influenced supportive attitudes toward forest conservation-related behaviors.

Chapter 3 uses an agent-based model (ABM) to examine what effect village attitudes toward forest conservation have on the future landscape and extent of forest cover if improved forest conservation-related policies are implemented, population growth rate fluctuates, and villages are able to mimic one another's attitudes toward forest conservation-related behaviors. In the Discussion, we give an overview of some of the challenges we encountered with modeling land use/land cover change (LULCC) in the place-specific context of Bachauli, Nepal. ABM allows users to conceptualize these ideas by examining how individual agents in a system (e.g., villages in Bachauli) are influenced differently by, and adapt in response to, input variables, which then aggregate to produce emergent, landscape-level outcomes. The model integrates remotely-sensed land cover data from Chapter 1 and household attitudes toward forest conservation, community forestry, and forest governance institutions in Nepal from Chapter 2. By 
coupling qualitative survey data and quantitative land cover data to model future LULCC scenarios, we hope that stakeholders—from NGOs, government agencies, to local communities - are better able to understand how improved forest policies, population growth, collective action, and household attitudes affect LULCC in Nepal.

\section{LITERATURE CITED}

Arnold, J. E. M. (1992). Community forestry ten years in review. Rome.

Gautam, A. P. (2007). Group size, heterogeneity and collective action outcomes: evidence from community forestry in Nepal. International Journal of Sustainable Development \& World Ecology, 14(6), 574-583.

http://doi.org/10.1080/13504500709469756

Gautam, A. P., Shivakoti, G. P., \& Webb, E. L. (2004). A review of forest policies, institutions, and changes in the resource condition in Nepal. International Forestry Review, 6(2), 136-148. http://doi.org/10.1505/ifor.6.2.136.38397

GoN (Government of Nepal). (2014). Review of implementation of the Master Plan for the Forestry Sector: achievements and lessons. Kathmandu.

HMGN (His Majesty’s Government of Nepal). (1993). Forest Act 1993. Kathmandu.

HMGN (His Majesty’s Government of Nepal). (1995). Forest Regulations 1995. Kathmandu. 
HMGN (His Majesty’s Government of Nepal), ADB (Asian Development Bank), \& FINNIDA (Finnish International Development Agency). (1988). Master Plan for the Forestry Sector Nepal: main report. Kathmandu.

Jackson, W. J., \& Tamrakar, R. M. (1998). Land-use changes in two Middle Hills districts of Nepal. Mountain Research and Development, 18(3), 193-212. http://doi.org/10.2307/3674033

Nagendra, H. (2007). Drivers of reforestation in human-dominated forests. Proceedings of the National Academy of Sciences of the United States of America, 104(39), 15218-23. http://doi.org/10.1073/pnas.0702319104

Nagendra, H., Tucker, C., Carlson, L., Southworth, J., Karmacharya, M., \& Karna, B. (2004). Monitoring parks through remote sensing: studies in Nepal and Honduras. Environmental Management, 34(5), 748-60. http://doi.org/10.1007/s00267-0040028-7

Nepal, S. K., \& Spiteri, A. (2011). Linking livelihoods and conservation: an examination of local residents’ perceived linkages between conservation and livelihood benefits around Nepal's Chitwan National Park. Environmental Management, 47(5), 727-738. http://doi.org/10.1007/s00267-011-9631-6

Pandit, R., \& Bevilacqua, E. (2011). Forest users and environmental impacts of community forestry in the hills of Nepal. Forest Policy and Economics, 13(5), 345-352. http://doi.org/10.1016/j.forpol.2011.03.009 
Panta, M., Kim, K., \& Joshi, C. (2008). Temporal mapping of deforestation and forest degradation in Nepal: Applications to forest conservation. Forest Ecology and Management, 256(9), 1587-1595. http://doi.org/10.1016/j.foreco.2008.07.023

Pravat, P. S. (2006). A history of forest politics in the Terai, Nepal: a case of equity or ecology? In ECPR Summer School on Environmental Politics. Staffordshire: Keele University School on Environmental Politics.

Schreier, H., Brown, S., Schmidt, M., Shah, P., Shrestha, B., Nakarmi, G., ... Wymann, S. (1994). Gaining forests but losing ground: a GIS evaluation in a Himalayan watershed. Environmental Management, 18(1), 139-150. http://doi.org/10.1007/BF02393756

Schweik, C. M., Nagendra, H., \& Sinha, D. R. (2003). Using satellite imagery to locate innovative forest management practices in Nepal. AMBIO, 32(4), 312-319. http://doi.org/10.1579/0044-7447-32.4.312

Spiteri, A., \& Nepal, S. K. (2008). Distributing conservation incentives in the buffer zone of Chitwan National Park, Nepal. Environmental Conservation, 35(1), 76-86. http://doi.org/10.1017/S0376892908004451

Stræde, S., \& Treue, T. (2006). Beyond buffer zone protection: a comparative study of park and buffer zone products’ importance to villagers living inside Royal Chitwan National Park and to villagers living in its buffer zone. Journal of Environmental Management, 78(3), 251-67. http://doi.org/10.1016/j.jenvman.2005.03.017 
Virgo, K. J., \& Subba, K. J. (1994). Land-use change between 1978 and 1990 in Dhankuta District, Koshi Hills, Eastern Nepal. Mountain Research and Development, 14(2), 159-170. http://doi.org/10.2307/3673798

World Bank. (2013). World Bank indicators - Nepal - land use, trading economics. Retrieved June 15, 2014, from http://www.tradingeconomics.com/nepal/forestarea-percent-of-land-area-wb-data.html 


\section{CHAPTER 1}

\section{EVALUATING THE IMPACTS OF FOREST MANAGEMENT POLICIES AND COMMUNITY-LEVEL INSTITUTIONS IN THE BUFFER ZONE OF CHITWAN NATIONAL PARK, NEPAL}

\section{CHAPTER ABSTRACT}

A Master Plan for Nepal’s Forestry Sector (MPFS), enacted in 1989, and subsequent legislation laid the foundation for modern community-based forest management in Nepal. In 2014, the MPFS reached the end of its 25-year lifespan, after successfully ushering in significant institutional changes that fundamentally transformed the management of Nepal's forests, mostly through devolving management and benefits from the national level to local communities. Here, we use the 25-year anniversary of the MPFS to explore forest cover trends in the buffer zone surrounding Chitwan National Park. Landsat imagery was used for the years 1989, 2005, and 2013 to compute a Normalized Difference Vegetation Index to analyze trends in forest cover for 36 buffer zone Village Development Committees. The analysis, covering approximately $1,267 \mathrm{~km}^{2}$, found that since the MPFS was enacted, there was first a continued decrease in forest cover, followed by a significant recovery overall. These data offer insight into the success of modern community-based forest management policies and supporting institutions, and provide a model for other efforts to conserve forest resources in Nepal and elsewhere. 


\section{INTRODUCTION}

Tropical forests are being cleared, converted and degraded on a global scale (Achard et al., 2002; Hansen et al., 2013). Forests, which today cover roughly one-quarter of Nepal, have witnessed a long history of decline and degradation due to rising human populations, agricultural expansion, and timber harvest. The concern over tropical forest loss has led countries such as Nepal to reconsider the way in which they manage and use forest resources. Today, Nepal is considered one of the best examples of successful community-based forest management in the world (Gautam et al., 2004).

Elinor Ostrom, in her 1990 book Governing the Commons: The Evolution of Institutions for Collective Action, discussed the complexities and fragility of successful self-governed and self-organized institutions for the management of common pool resources (CPRs). Her later work explored the effectiveness of decentralized approaches to CPR management in Nepal, as well as similar initiatives in other parts of the world (see e.g. Ostrom et al., 1993; Agrawal \& Ostrom, 2001; Shivakoti \& Ostrom, 2002; Andersson \& Ostrom, 2008). The importance of institutional structure has since been widely discussed in the human dimensions of natural resource management and economics literature. Indeed, under various ecological and social conditions, decentralized community-level forest management has shown promise in reversing forest loss and degradation in Nepal (see e.g. Chakraborty, 2001; Agrawal \& Gupta, 2005;

Gautam \& Shivakoti, 2005; Nagendra et al., 2005; Gautam, 2007; Gurung et al., 2013).

Modern community forestry in Nepal, however, began only after a long history of political instability and rigid and hierarchical centralized forest management institutions. 
During the mid-20th Century, the lowland forests of southern Nepal were rapidly cleared in response to national policies promoting timber harvest, agricultural expansion, and malaria eradication (Schweik et al., 2003). The eradication of malaria in the south, along with the construction of more improved road systems increased migration into the Terai, development, and more profitable commercial forestry. Increasing settlements made agriculture more important in the region, as the Terai is known as the fertile 'bread basket' of Nepal. And, increased clearing for agriculture made more land available for migrants from less productive regions of the country (Pravat, 2006).

An important milestone in Nepal's forest management policy was the 1957 Nationalization Act, which established the government's ownership of all forested land in the country. The Act, which was implemented to ensure that the state had complete control of the country’s commercial timber market (Agrawal \& Ribot, 1999; Jones, 2007), was adopted to usurp control of privately owned forests and lands following the collapse of the Rana regime in 1951. Privatized ownership ceased and control was placed in the hands of the central state to oversee commercial timber harvesting and management of forest resources. An unintended consequence was that the Act undermined community-level management practices, which significantly accelerated the trend of deforestation (Guthman, 1997; Agrawal \& Ostrom, 2001; Pravat, 2006; Upadhaya, 2010; Pandit \& Bevilacqua, 2011). Bajracharya (1983) quotes FAO (1979) by stating that: 
after nationalization of the forest, the people considered that the state was taking away their rights in the forests and lost their sense of responsibility; they did not feel there was any necessity to conserve the forests... The effect of the Nationalization Act was to accelerate forest degradation (p. 233).

A major factor fueling deforestation was the inability of the Nepali government to oversee all of the country's forested land - especially in remote rural areas. Additionally, rural communities wanted the power to manage their own forested lands (Upadhaya, 2010), and their traditional management practices were challenged and replaced by a centralized management system. In 1961, King Mahendra implemented the Panchayat system — a party-less system of government, guided by the monarchy — which overthrew the brief democratic system that had been formed for one year. Extensive forest clearing and timber exports occurred until the return of a multi-party, democratic government in 1990 . As much as $25 \%$ of forests in the Terai region were harvested in this time, with much of the wood sold to India (Pravat, 2006).

Between 1961 and 1970, the Nepali government worked to prevent rural populations from having any forest-related rights (Agrawal \& Ostrom, 2001). This changed in 1976, when the National Forestry Plan was enacted which, for the first time, highlighted the need for collective action in Nepal. Before this, collective action was not considered a necessary part of the solution to resource problems. In a marked departure from past policy, the Nepali government stated that "protection, maintenance, and development of forests scattered all over the kingdom is neither possible nor even 
practical through government efforts alone” (Bajracharya, 1983, p. 234). Henceforth, decentralized natural resource management was official policy. Nepal, like many other struggling, developing countries, devolved power from centralized control to citizens in an attempt to better meet common needs (Jones, 2007).

The Master Plan for the Forestry Sector (MPFS), established in 1988 by the Ministry of Forests and Soil Conservation (MFSC) and enacted in 1989, set in place a 25year forest management framework for Nepal. The MPFS had four primary objectives:

(1) to meet the people's basic needs for forest products on a sustained basis; (2) to conserve ecosystems and genetic resources; (3) to protect land against degradation and other effects of ecological imbalance; and (4) to contribute to local and national economic growth (Forestry Nepal, 2014, p. 1, citing HMGN, ADB, \& FINNIDA, 1988).

Attention was focused on building programs that benefited community-managed forests, such as reforesting community-managed parcels of forest and subsidizing tree seedling production and nurseries. There were implications for the commercial forest industry in Nepal as well. Under the Plan, foresters were to seek training in new forest management approaches, and the Ministry invested in research and development on sustainable silvicultural methods.

The Forest Act of 1993 and the Forest Rules and Regulations of 1995 were subsequently passed to establish regulations for government-managed forests, protected 
forests, private and leasehold forests, and community forests (HMGN, 1995).

Importantly, the National Parks and Wildlife Conservation Act was passed in 1973 by Nepal's Department of National Parks and Wildlife Conservation (DNPWC), and the Act's 4th Amendment, passed in 1993, officially designated a buffer zone around Chitwan National Park (CNP) and gave limited rights to inhabitants to manage forests therein (Spiteri \& Nepal, 2008 citing Heinen \& Mehta, 2000; Nepal \& Weber, 1995). The Act implemented official buffer zone policies for those living around CNP to help address problems with resource management in and around the park. For example, in 1993, there was severe flooding in CNP from the Rapti River. The Park Buffer Zone Program contributed trees to be planted in the area to help reforest and stabilize the degraded floodplain, helping to protect against future flooding, as well as expanding habitat for wildlife (Nagendra et al., 2007).

In addition, the Buffer Zone Management Regulations of 1996, and the Buffer Zone Management Guidelines of 1999, were implemented "for the design of programs compatible with national park management and to facilitate public participation in the conservation, design and management of buffer zones” (Budhathoki, 2004, p. 335 citing HMGN, 2002). CNP's buffer zone includes approximately $750 \mathrm{~km}^{2}$ and is home to more than 300,000 people (Stræde \& Treue, 2006). In part, buffer zones were established to mitigate anthropogenic harm to national parks from communities living nearby by giving residents alternatives for economic self-sufficiency through managing resources outside park boundaries and alleviating use of protected resources. 30-50\% of (CNP) revenues are distributed to buffer zones communities to support development programs designed to improve health, living, and sanitation conditions, education, and awareness of 
environmental issues (Budhathoki, 2004). In addition, the law supports the formation and use of User Group Committees (UGC) to further local involvement and distribute responsibility. Overall, the goal of these buffer zone programs is to mitigate potential negative impacts that protected areas may have on adjacent communities, and to lessen the negative impacts that communities might have on protected areas in return (Budhathoki, 2004). The 1993 amendment to the National Parks and Wildlife Conservation Act, the Buffer Zone Management Regulations of 1996, and the Buffer Zone Management Guidelines of 1999 sought to preserve the natural environment with the help and participation of the communities living in the designated buffer zone. These communities work with park officials to improve socio-economic conditions for both parks and communities, thus making CNP a noteworthy example of communities working together with the government to preserve the rich biodiversity and natural resources of a protected area (UNESCO, 2013).

Community Forest User Groups (CFUGs) and Buffer Zone Community Forest User Groups (BZCFUGs; from here forward, 'CFUG' will be used interchangeably) were given limited authority to use and manage government forests in and around their communities, though forests were technically still owned by the state. CFUGs in nonbuffer zone community forests coordinate efforts with the Forestry Department and a District Forest Officer, who assists the group in writing rules/operational plans that dictate how the CFUG will manage forest resources. CFUGs in buffer zone community forests develop their constitution in accordance with operating rules set in place by CNP authorities and a Chief Warden who oversees buffer zone forest management programs. A second plan/constitution is created that sets rules for the internal management of the 
CFUG within the community. After state-owned land is approved for community forest use, a five-year management plan is developed for each parcel. Importantly,

the District Forest Officer can hand over any part of a national forest to a user group in the form of a community forest, entitling it to develop, conserve, use, and manage the forest, and to sell and distribute forest products by independently fixing the price in the market (Agrawal \& Ostrom, 2001, p. 499).

Nagendra et al., 2005 examined the operational differences between user groups in community forests and buffer zone forests around CNP, noting substantial differences in terms of property rights, monitoring effectiveness, rules for harvesting, the freedom to change rules in place, and economic support—both external and within the user group. A large portion of income generated from CFUGs in buffer zone community forests typically comes from tourism entrance fees, and, unlike CFUGs in non-buffer zone community forests, proportionally less revenue is received from harvesting and membership fees paid to the forest user group (Nagendra et al., 2005). Additionally, in order to promote forest conservation, CFUGs were not permitted to convert forests into agricultural lands. Each CFUG elects community members to assist in various tasks such as guarding resources and controlling access and use, distributing revenues among CFUG members from the sale of forest products, improving forest conditions, and applying sanctions to violators. Monitoring within buffer zone community forests CFUGs is 
typically done by hired forest guards with revenue generated from tourism entrance fees from CNP (Nagendra et al., 2005). Finally, as revenues are generated, 25\% are returned to the community (beyond CFUG members) to promote broader development programs (Guthman, 1997). By 1999, there were 8,500 CFUGs operating in Nepal, representing nearly one million households and managing over $6,500 \mathrm{~km}^{2}$ of forest - roughly $10 \%$ of Nepal's total forest area (Agrawal \& Ostrom, 2001). Today, over 13,500 CFUGs are recognized nationwide (FECOFUN, 2014).

In combination, the core goal of the MPFS, The Forest Act of 1993, and the Forest Rules and Regulations of 1995 was to bestow access and management authority to recognized community groups that were willing to manage and rehabilitate degraded forests for the benefit of local communities. With rules in-place, CFUGs received limited rights to grow, harvest, sell, and manage forests, in accordance with the Forestry Department, Chief Warden, and CNP authorities.

A growing body of evidence - both anecdotal and empirical - suggests that these policy changes have been effective in decentralizing management and reducing rates of forest loss. Many studies suggest that the emergence of community forestry has been an important driver in resolving forest resource issues over the last 25 years (see, e.g., Stræde and Treue, 2006; Gautam, 2007; Nagendra, 2007; Spiteri \& Nepal, 2008; Nepal \& Spiteri, 2011).

Here, we use remote-sensing techniques to examine trends in forest loss and gain over the last 25 years, and set these trends within the context of the emergence of community-based management and modern forestry policies in the buffer zone of CNP. Remote sensing and GIS techniques have been widely used to analyze forest cover 
dynamics in Nepal since the establishment of modern forestry legislation (see e.g., Jackson et al., 1998; Schreier et al., 1994; Virgo \& Subba, 1994; Panta et al., 2008), and been found to provide a spatio-temporal perspective when analyzing the relative success of forest management policies (Nagendra et al., 2004).

\section{MATERIALS AND METHODS}

\section{Study Area}

Chitwan National Park (CNP) is located on the southern border of Nepal, close to India in the Terai region (Figure 1.1). Established in 1973, CNP is a UNESCO-designated World Heritage Site. Covering $932 \mathrm{~km}^{2}$, it is a sanctuary for a diverse tropical ecosystem with many species of endangered flora and fauna such as the one-horned Asian rhinoceros (Rhinoceros unicornis), the Royal Bengal tiger (Panthera tigris tigris), and the Asian elephant (Elephas maximus). It is considered subtropical lowland and lies at the foot of the Himalayan Mountains between two rivers, the Narayani and the Rapti. The park is surrounded by four districts: Chitwan, Parsa, Nawalparasi, and Makwanpur. Additionally, the Parsa Wildlife Reserve (PWR) is located to the east and adjacent to CNP, and in 2003, Beeshazar and its associated lakes located in the northern buffer zone of CNP were designated as a globally important Ramsar site (UNESCO, 2013). Together, CNP and PWR cover approximately $1,431 \mathrm{~km}^{2}$ of mostly forested land. 


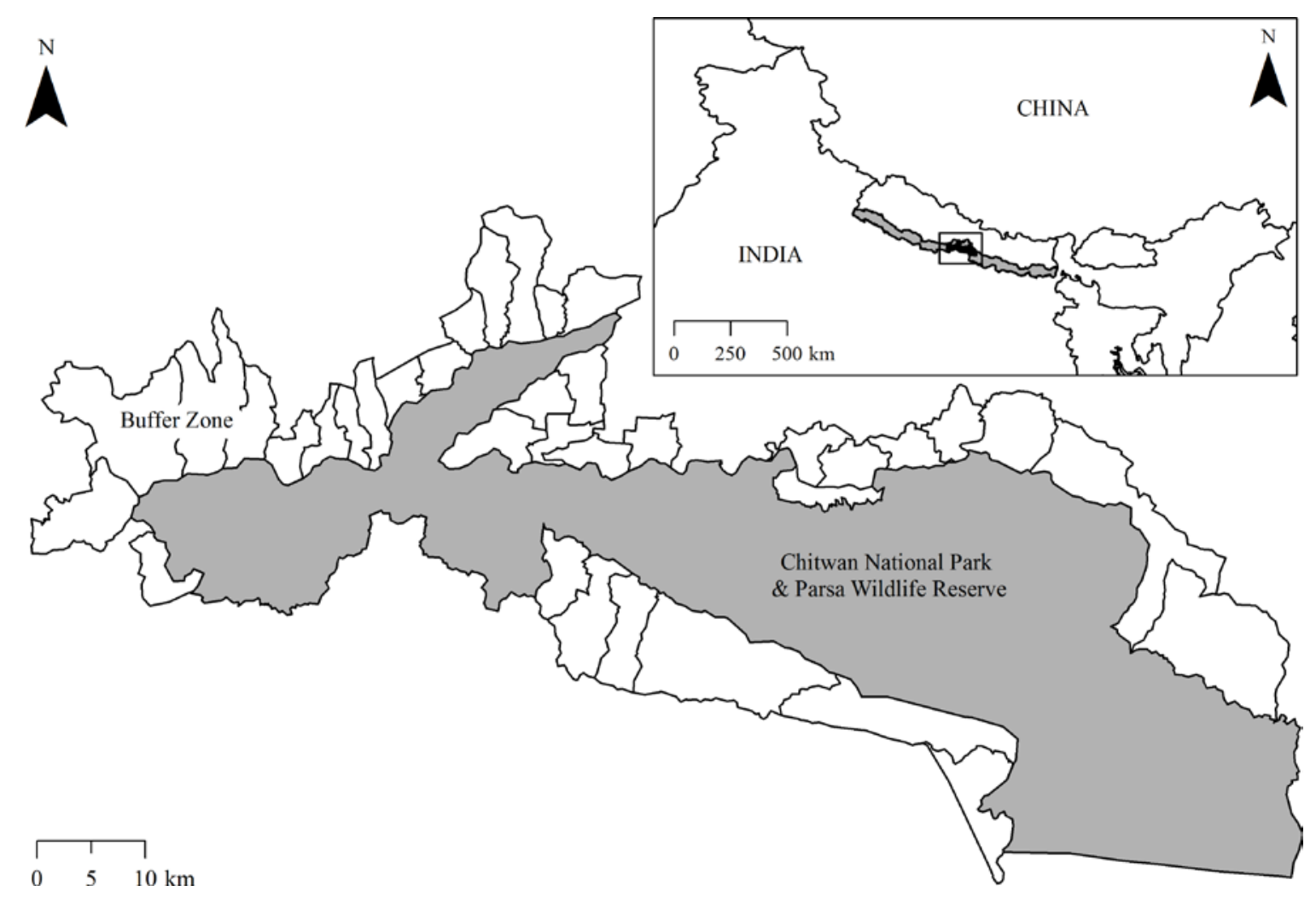

Figure 1.1. Terai region of Nepal, Chitwan National Park, and the 36 village development committees (VDCs) in the buffer zone.

CNP has a long history of human influence. It was originally named Royal Chitwan National Park, protected as a hunting preserve for the Nepali royal family and other elites to hunt large game such as tiger, rhinoceros, and elephant. Malaria was rampant until its eradication in the 1950s and 1960s. At that time, the park was fairly remote and inaccessible. New and improved roads were constructed to connect CNP with other areas of Nepal. Forests were cleared to provide land for agriculture, and a growing rural population increasingly impacted the landscape. 
The dominant indigenous population endemic to the buffer zone of CNP is the Tharu people. The total population of the 36 Village Development Committees (VDCs) in CNP's buffer zone rose from 292,000 in 2001 (HMGN, 2001), to over 400,000 in 2011 (GoN, 2011). Importantly, the official buffer zone around CNP does not encompass the entirety of every VDC that is located within its vicinity (Stræde \& Treue, 2006). For this study, the whole area of each of the 36 VDCs in the CNP buffer zone was analyzed approximately $1267 \mathrm{~km}^{2}$ compared to the $750 \mathrm{~km}^{2}$ that technically falls within the designated buffer zone. The average annual income in the area is \$210 USD (Stræde \& Treue, 2006), relatively low when compared to the gross national income per capita $\$ 730$ USD (World Bank, 2013). The average household contains 7.1 people with just $48 \%$ of working age; $41 \%$ are under the age of 15 (Stræde \& Treue, 2006). Low incomes, in-migration from India and other regions of Nepal, and large family sizes make subsistence resources very important.

\section{Data Used and Data Analysis}

Using Landsat imagery, a Normalized Difference Vegetation Index (NDVI) was calculated for the years 1989, 2005, and 2013 to explore changes in forest cover over time. The United Nations' collaborative initiative on Reducing Emissions from Deforestation and forest Degradation (REDD, 2014) estimated that overall forest loss in Nepal fell to zero percent annually between 2005 and 2010. Additionally, a 10-year Maoist civil war in Nepal ended in 2006, greatly reducing political and social instability. For this reason an intermediate year - i.e., 2005 - was used to demarcate two periods (1989-2005 and 2005-2013) to highlight the positive trend that has appeared in recent 
years. The analysis was conducted for the 36 VDCs in the buffer zone to identify which VDCs had experienced the greatest rates of forest loss and forest growth.

Shorea robusta is the dominant forest type in this region of the Terai region of southern Nepal, and the NDVI analysis was specifically designed to measure changes in cover of this important forest type. Importantly, the Landsat scenes that were used for this analysis were all from the same time of year, selected to be as close to one another as possible to minimize phenological differences in vegetation due to leaf fall or seasonal differences in vegetation moisture content. For detection of Shorea robusta forest, Panta et al. (2008, p. 1588) recommend the use of imagery from “October, November, and December, shortly after cessation of the monsoon but before leaf fall.” In addition to Landsat data, historical aerial photographs from 1989 and historical DigitalGlobe imagery via Google Earth Pro from 2005 and 2013 were used to verify NDVI classifications (Table 1.1). 
Table 1.1. Remote sensing and GIS data used for NDVI analysis.

\begin{tabular}{|c|c|c|c|c|c|}
\hline $\begin{array}{l}\text { Satellite } \\
\text { \& Data }\end{array}$ & Path & Row & $\begin{array}{l}\text { Date of } \\
\text { acquisition }\end{array}$ & $\begin{array}{l}\text { Bands (wavelength in } \\
\text { micrometers) }\end{array}$ & Source \\
\hline Landsat 5 TM & 141 & 41 & Oct. 31, 1989 & $\begin{array}{l}\text { Band } 3 \text { visible red }(0.63-0.69 \\
\mu \mathrm{m}) \\
\text { Band } 4 \text { near-infrared }(0.76 \text { - } \\
0.90 \mu \mathrm{m})\end{array}$ & $\begin{array}{l}\text { USGS } \\
\text { Glovis }\end{array}$ \\
\hline Landsat 5 TM & 142 & 41 & Nov. 7, 1989 & $\begin{array}{l}\text { Band } 3 \text { visible red }(0.63-0.69 \\
\mu \mathrm{m}) \\
\text { Band } 4 \text { near-infrared }(0.76 \text { - } \\
0.90 \mu \mathrm{m})\end{array}$ & $\begin{array}{l}\text { USGS } \\
\text { Glovis }\end{array}$ \\
\hline Landsat 5 TM & 141 & 41 & Nov. 12, 2005 & $\begin{array}{l}\text { Band } 3 \text { visible red }(0.63-0.69 \\
\mu \mathrm{m}) \\
\text { Band } 4 \text { near-infrared }(0.76 \text { - } \\
0.90 \mu \mathrm{m})\end{array}$ & $\begin{array}{l}\text { USGS } \\
\text { Glovis }\end{array}$ \\
\hline Landsat 5 TM & 142 & 41 & Nov. 19, 2005 & $\begin{array}{l}\text { Band } 3 \text { visible red }(0.63-0.69 \\
\mu \mathrm{m}) \\
\text { Band } 4 \text { near-infrared }(0.76 \text { - } \\
0.90 \mu \mathrm{m})\end{array}$ & $\begin{array}{l}\text { USGS } \\
\text { Glovis }\end{array}$ \\
\hline $\begin{array}{l}\text { Landsat } 8 \text { OLI- } \\
\text { TIRS }\end{array}$ & 141 & 41 & Nov. 25, 2013 & $\begin{array}{l}\text { Band } 4 \text { visible red }(0.64 \text { - } \\
0.67 \mu \mathrm{m}) \\
\text { Band } 5 \text { near-infrared }(0.85 \text { - } \\
0.88 \mu \mathrm{m})\end{array}$ & $\begin{array}{l}\text { USGS } \\
\text { Glovis }\end{array}$ \\
\hline $\begin{array}{l}\text { Landsat } 8 \\
\text { OLI-TIRS }\end{array}$ & 142 & 41 & Dec. 4, 2013 & $\begin{array}{l}\text { Band } 4 \text { visible red }(0.64 \text { - } \\
0.67 \mu \mathrm{m}) \\
\text { Band } 5 \text { near-infrared }(0.85 \text { - } \\
0.88 \mu \mathrm{m})\end{array}$ & $\begin{array}{l}\text { USGS } \\
\text { Glovis }\end{array}$ \\
\hline $\begin{array}{l}\text { Historical aerial } \\
\text { photographs }\end{array}$ & & & 1989 & & $\begin{array}{l}\text { GoN, } \\
1989\end{array}$ \\
\hline
\end{tabular}

Landsat imagery was acquired from the US Geological Survey and pre-processed using ArcMap 10.2 before NDVI was computed. The digital number (DN) for each Landsat band was converted into top-of-atmosphere (TOA) spectral radiance, which is the amount of energy in watts at the satellite's sensor for each cell on the ground. The formula uses the DN, the highest and lowest cell values, and radiance values, which vary with the gain state of the sensor (Johnson, 2013). For Landsat 8, band-specific multiplicative and additive rescaling factors were also used in the radiance calculation (U.S. Geological Survey, 2013). TOA radiance was then converted to TOA reflectance, a normalized, unitless measure of the ratio of the amount of light energy reaching the earth's surface to 
the amount of light reflecting off the surface and returning to the top of the atmosphere and thus detected by the satellite's sensors. The formula considers spectral radiance, distance from the earth to the sun, the mean solar exoatmospheric irradiance, the day of year, and the solar zenith angle (Johnson, 2013; U.S. Geological Survey, 2013).

All but one Landsat scene was cloud-free for the study area. The exception had very limited cloud cover, and virtually all clouds were located within the boundaries of CNP and not within the study area. A cloud mask was created to extract those areas from the scene. The same areas were omitted from all Landsat scenes used in the analysis, approximately 354 ha of the total 126,700 ha examined in the analysis, or $0.28 \%$. Because the clouds were located almost entirely within CNP, the effect on this analysis was minimal.

NDVI was computed using model builder in ArcMap 10.2 using the following formula:

$$
\text { NDVI = (near infrared }- \text { red }) /(\text { near infrared }+ \text { red })
$$

The formula uses the visible red and near infrared (NIR) bands. The bands allow the user to determine vegetation cover in an image, as vegetation has different spectral reflectance as compared to other land cover types. The NDVI value is based on the difference between the reflectance of NIR and red light. Where NIR reflectance is much higher than red reflectance, the value is closer to one, on a -1 to 1 scale. Dividing by the total amount of reflected light in both bands normalizes the data to allow comparisons between pixels. 
Historic aerial photographs of the Chitwan District in 1989 (obtained from Panta et al., 2008; HMGN, 1989) were scanned and georeferenced using first order transformation. These, in addition to historical images from DigitalGlobe were used to ground-truth the classification of NDVI values for the years 1989, 2005 and 2013. One hundred points were randomly generated in ArcMap 10.2 within the extent of the 1989 aerial photographs. For each point in the 1989 aerial image, land cover type was determined by visual inspection and compared with the NDVI classification for 1989 to check for accuracy of the classification. The same points were used with historic images from DigitalGlobe for the accuracy assessment of the 2005 and 2013 NDVI images. Overall, the classification accuracy was $97 \%$ with a $0.7 \%$ bias for forest and $2.3 \%$ bias for non-forest (Table 1.2).

Table 1.2. Accuracy assessment for NDVI reclassification.

\begin{tabular}{|c|c|c|c|c|c|c|c|c|}
\hline & & \multicolumn{6}{|c|}{ Classified in Landsat image as: } & \multirow{3}{*}{$\begin{array}{l}\text { Number of ground } \\
\text { truth points }\end{array}$} \\
\hline & & \multicolumn{2}{|c|}{1989} & \multicolumn{2}{|c|}{2005} & \multicolumn{2}{|c|}{2013} & \\
\hline & & Forest & $\begin{array}{l}\text { Non- } \\
\text { forest }\end{array}$ & Forest & $\begin{array}{l}\text { Non- } \\
\text { forest }\end{array}$ & Forest & $\begin{array}{l}\text { Non- } \\
\text { forest }\end{array}$ & \\
\hline \multirow{2}{*}{$\begin{array}{l}\text { Ground truth } \\
\text { points }\end{array}$} & Forest & 56 & 1 & 46 & 3 & 47 & 3 & 156 \\
\hline & $\begin{array}{l}\text { Non- } \\
\text { forest }\end{array}$ & 1 & 42 & 0 & 51 & 1 & 49 & 144 \\
\hline \multicolumn{2}{|c|}{ Accurate points } & \multicolumn{2}{|c|}{98} & \multicolumn{2}{|c|}{97} & \multicolumn{2}{|c|}{96} & 300 \\
\hline \multicolumn{2}{|c|}{ Total accuracy } & \multicolumn{6}{|c|}{$\mathbf{9 7 \%} \quad[0.7 \%$ bias for forest; $2.3 \%$ bias for non-forest $]$} & \\
\hline
\end{tabular}


Zonal statistics were computed with the overlaying VDC polygons to calculate the amount of forest present in each area for each year. Differences between years were calculated using the classified NDVIs, which were subtracted from one another to display areas of forest loss, no change, and gain. Statistical analysis was conducted using the 'Stats Package' in version 3.1.2 of the R Statistical Computing Software (R Core Team, 2014). T-tests with a 95\% confidence interval were computed to compare the difference in means for percent of total area forested and total number of forested hectares per VDC between 1989 and 2005, 2005 and 2013; and 1989 and 2013.

\section{RESULTS}

Analysis of NDVI revealed that in total, VDCs in the buffer zone lost $9.9 \%$ of total forest cover between 1989 and 2005, and regained 7.5\% between 2005 and 2013; the net loss between 1989 and 2013 was 3.1\% (Table 1.3). Significant differences were found in the percent of total area forested and total number of forested hectares per VDC between the years 1989 and 2005, and between 2005 and 2013 ( $p$ <0.05). For example, mean hectares of forest per VDC declined from 1,753 in 1989 (34.5\% of VDC area), to 1,581 hectares in 2005 (32.3\% of area). Mean VDC hectares increased to 1,700 by 2013, thus comprising $36.5 \%$ of total VDC area. 
Table 1.3. Forest change between 1989, 2005, and 2013 based on NDVI analysis.

\begin{tabular}{|c|c|}
\hline Overall \% change in forest cover: 1989 - 2005 & $-9.9 \%$ \\
\hline Overall \% change in forest cover: 2005 - 2013 & $+7.5 \%$ \\
\hline Overall \% change in forest cover: 1989 - 2013 & $-3.1 \%$ \\
\hline Mean hectares of forest per VDC: 1989 & 1753.9 ha \\
\hline Mean hectares of forest per VDC: 2005 & 1581.3 ha \\
\hline Mean hectares of forest per VDC: 2013 & 1700.1 ha \\
\hline Mean \% of total area forest per VDC: 1989 & $34.5 \%$ \\
\hline Mean \% of total area forest per VDC: 2005 & $32.3 \%$ \\
\hline Mean \% of total area forest per VDC: 2013 & $36.5 \%$ \\
\hline Mean population growth per VDC: 1991 - 2011 & $39.0 \%$ \\
\hline \multicolumn{2}{|l|}{ T test for \% of total area forested among 36 VDCs } \\
\hline $1989 \& 2005$ & $1989 \& 2013$ \\
\hline $\mathrm{p}<0.05$ & $\mathrm{p}>0.1$ \\
\hline \multicolumn{2}{|l|}{ T test for number of forested hectares per VDC } \\
\hline $2005 \& 2013$ & $1989 \& 2013$ \\
\hline $\mathrm{p}<0.05$ & $\mathrm{p}>0.33$ \\
\hline
\end{tabular}

Interestingly, no significant difference between means was found between 1989 and 2013 for the percentage of total area forested among 36 VDCs $(p>0.1)$ or for the number of forested hectares per VDC ( $p>0.33)$, suggesting that total forest cover in the area has largely regenerated to the levels that existed in 1989 (Table 1.3). Note, however, that the characteristics of regenerated forest seen today are likely to vary significantly from 1989 
conditions with respect to species, age, and ecological function. Moreover, this rebound in forested area has occurred despite a 39\% increase in population between 1991 and 2011.

Figure 1.2 shows the temporal distribution of forest cover by VDC for years 1989, 2005, and 2013. In all years, high human populations are indicated by non-forest areas in the central region around CNP. Note that the occurrence of forest adjacent to CNP is mostly found in the eastern portions of the study area and the extreme west. Figure 1.3 shows forest cover change from 1989 to 2005, and from 2005 to 2013. The greatest levels of both loss and regeneration were found in the VDCs located to the north and south of the central portion of CNP (Figures 1.2 and 1.3). Notably, the north-central area of the buffer zone has seen high rates of human population growth, development, and ecotourism over the last 25 years. 


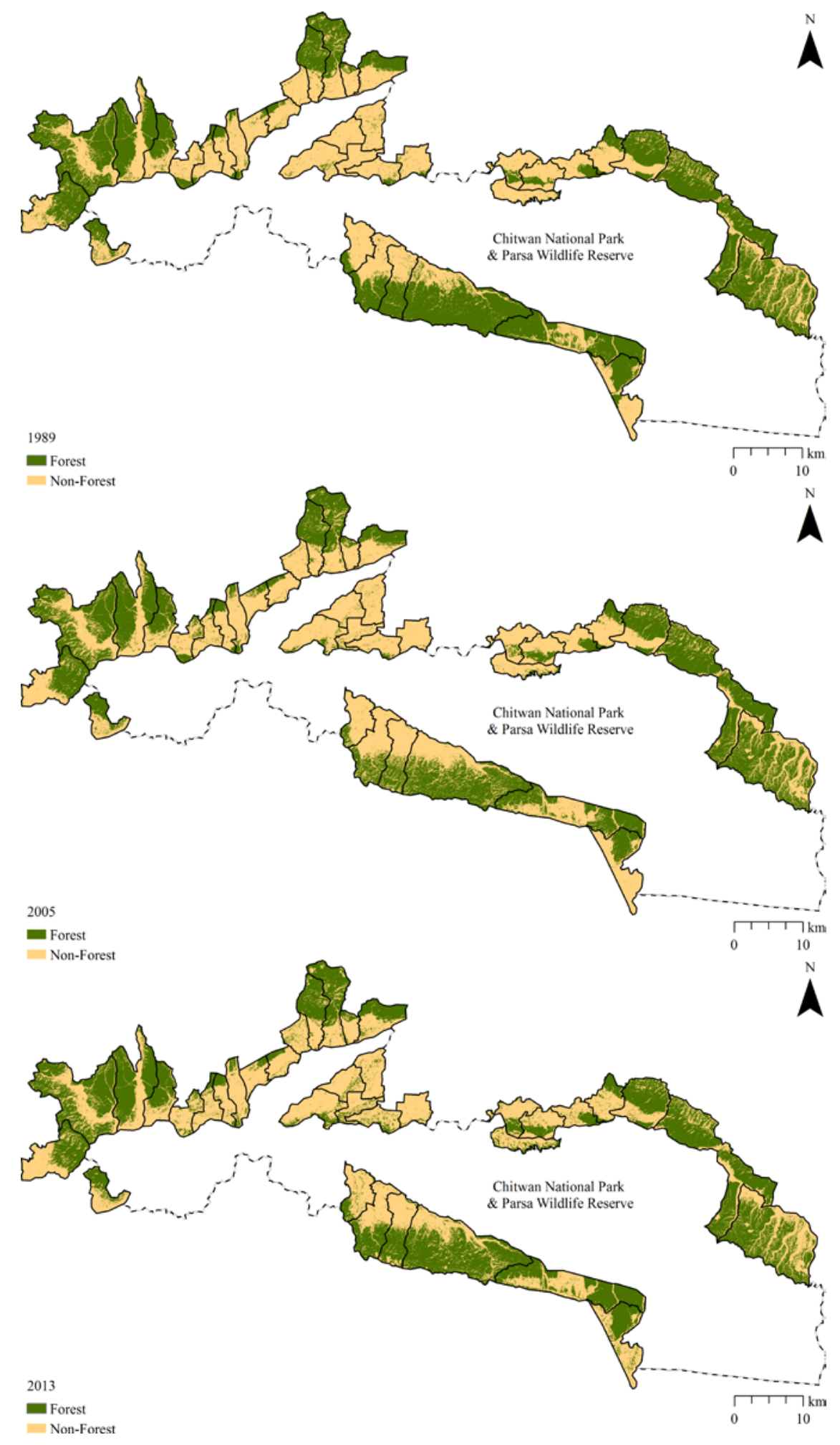

Figure 1.2. Forest cover in the buffer zone of Chitwan National Park (CNP) in 1989, 2005, and 2013. 


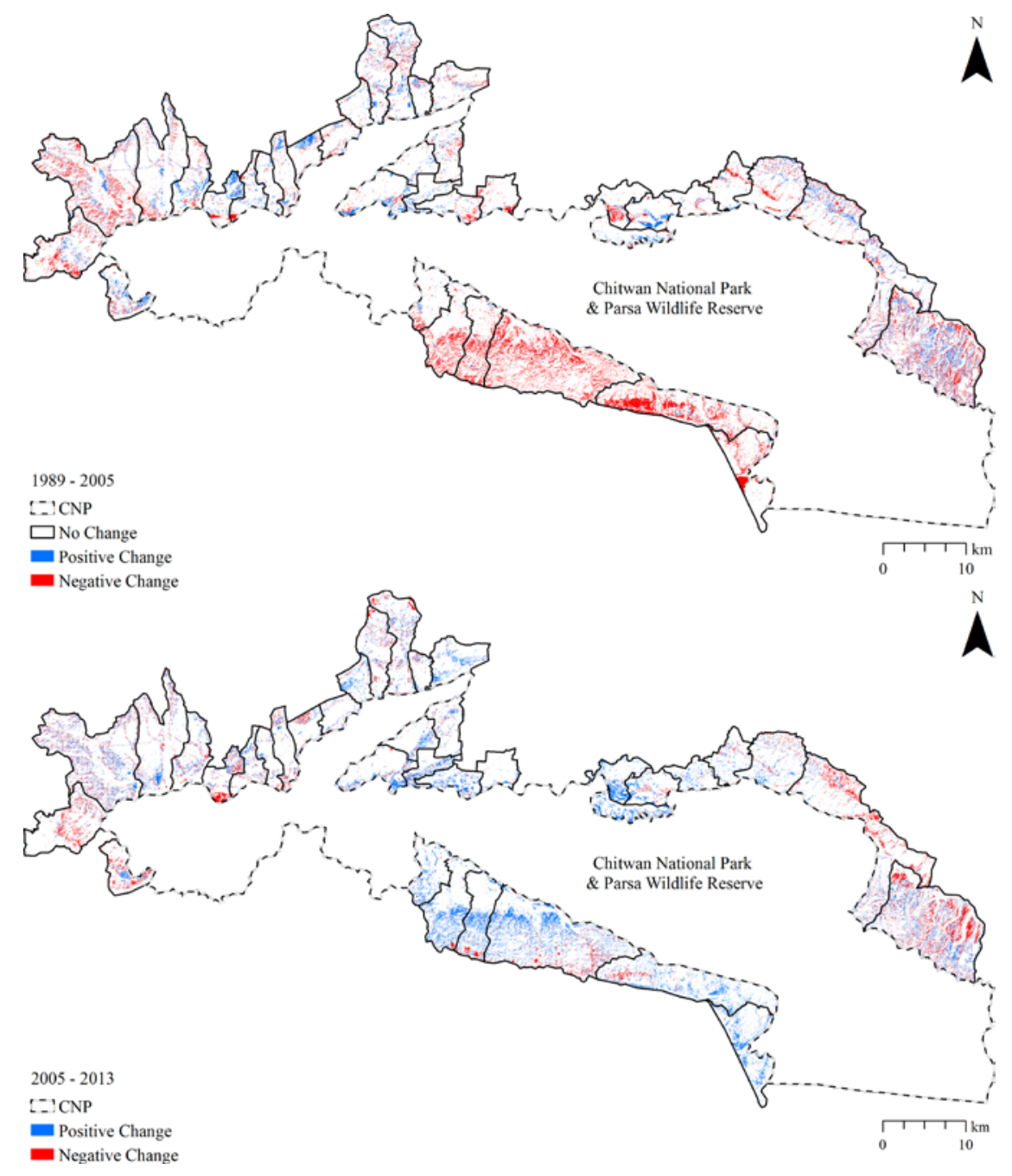

Figure 1.3. Forest cover change in the buffer zone of Chitwan National Park (CNP) between 1989-2005 and 2005-2013.

\section{DISCUSSION AND CONCLUSION}

Our NDVI analysis found that forest conditions within CNP's buffer zone have begun to stabilize between 2005 and 2013. Forests have seen significant regeneration in the study area, a trend consistent with other reports of current rates of deforestation and forest 
degradation in Nepal that suggest a deceleration in forest loss on a national level. Indeed, the total percentage of forest cover in Nepal was stable at 25.4\% in 2005 (REDD, 2014), and World Bank (2013) data indicate consistent levels in 2009, 2010, and 2011. While there have not been many recent forest cover NDVI analyses done for our study area, our results partially coincide with the results of another NDVI deforestation study conducted in the Chitwan district adjacent to CNP by Panta et al. (2008). The study found that between 1989 and 2001, forest cover in the Chitwan District fell 7.95 percent, whereas our study found that for all VDCs in the buffer zone of CNP, forest cover fell 9.9 percent between 1989 and 2005.

The cessation of forest loss in Nepal is likely due to a combination of factors. We suggest here that decentralized forest management institutions such as community forestry have played an important role in not just slowing, but halting and possibly reversing forest loss and degradation in areas of the buffer zone of CNP. Alongside this trend, the number of CFUGs is continually growing.

There are other factors that have likely contributed to the reversal of historic forest trends - e.g., the adoption of energy-efficient technologies such as home biogas systems, improved cooking stoves, and increased attention from international aid, donors and NGOs. Moreover, a large array of groups and organizations have sought to promote community-based forest management as a method to devolve management authority from the state to local-level institutions to manage as they see fit the forests that contribute to the social, economic and ecological health of communities. NGOs such as the World Wildlife Fund and SeedTree Nepal have helped implement energy-efficient technologies, establish tree seedling nurseries, and educate communities about how to sustainably 
manage local forests. Fuel efficient stoves and biogas are increasingly common in homes nationwide, partially due to NGOs and international aid.

These findings should be tempered by uncontrolled variables not considered in our NDVI study. Indeed, there are many factors, both natural and anthropogenic, which affect forest loss and regeneration in CNP's buffer zone. For example, the Rapti and Narayani Rivers border CNP, and because this area of the Terai region is subtropical lowland, it experiences a long annual monsoon season that begins in summer. The monsoon season brings heavy, consistent rains that can cause the rivers to flood and erode banks. Landslides and mudslides are also common during the monsoon season, and can have significant effects on the landscape, which increases as erosion-protecting forests are removed. As a result, when considering the changes in forest cover in Figures 1.2 and 1.3, it is important to realize that a small percentage of the change could be attributed to the monsoon season and changes in the two rivers' paths over time, particularly where the northern border of CNP meets the buffer zone. Also, when forests are regenerated, the quality of forest and the benefits it has on the ecosystem are likely limited when compared to original stands. Here, we examined human aspects of forest systems in the buffer zone of CNP, and further work needs to be done to enhance our knowledge about the relative quality of new forested lands in the area.

Importantly, this study does not distinguish between areas located within the buffer zone of CNP, but rather examines all forests located within the VDCs that lie within the buffer zone. Furthermore, this study does not examine the difference in forest loss and regeneration rates between regular community forests and buffer zone community forests, which operate quite differently in terms of property rights, 
monitoring effectiveness, rules for harvesting, the freedom to change rules in place, and economic support — both external and within the user group. Nagendra et al. (2005) conducted an NDVI remote sensing analysis of both community forests and buffer zone community forests around CNP, and found that between 1989 and 2000, the amount of forest loss was significantly lower and the amount of regeneration was significantly higher in buffer zone forests when compared with regular community forests. Perhaps the outcomes of our study would have been more congruent with these results had we distinguished between regular and buffer zone forests. However, we sought to examine the larger areas surrounding CNP considering both forest management regimes-i.e., community forests as well as buffer zone forests.

The indigenous Tharu people living in the buffer zone of CNP have a substantial impact on the forested landscape, and further studies are needed to better understand the Tharu people's traditional forestry system, and how it differs and resembles community forestry in Nepal today. Stevens (2003) examined the effects of protected areas on indigenous communities around Nepal's Sagarmatha National Park, noting that the indigenous Khumbu Sherpas of the area feared that the park, created in 1976, would hinder their traditional use and management of natural resources. "These fears soon proved justified when national park authorities announced new policies in 1979 that not only banned tourist campfires but also banned all felling of trees by Sherpas and enforced the new regulations with an army 'protection unit'” (Stevens, 2003, p. 258 citing Stevens, 1983; Brower 1991a; Brower, 1991b; Stevens, 1993; Stevens, 1997; Brower \& Dennis, 1998). Baral \& Heinen (2007) also found that the establishment of protected areas in Nepal's Terai region alienated local populations and reduced much-needed access to 
resources. Moreover, the eventual liberalization of park regulations resulted in more supportive attitudes of local people.

Forest cover change in our study area is likely due in part to the effects of CNP on the ways that Tharu people manage and perceive forests since the establishment of CNP and the buffer zone around it. Further research is needed to better understand how these institutional changes towards indigenous management systems have influenced forest regeneration and loss trends in the Terai region.

Finally, and importantly, our analysis represents only a subset of the forested landscape that exists today in Nepal, albeit an ecologically and socially important region. However, when compared with data from sources such as the World Bank and United Nations, we suggest that the trends we found here could be representative of a much broader area. Although Nepal's forests have historically experienced high rates of deforestation and forest degradation, there is hope for the protection and regeneration of these resources with decentralized control in partnership with community forestry programs.

\section{ACKNOWLEDGMENTS}

This research was supported by National Science Foundation award EPS-0904155 to the Maine EPSCoR Sustainability Solutions Initiative at the University of Maine, McIntireStennis grant number MEO-M-700510-13, and the USDA National Institute of Food and Agriculture. Additional support was provided by the Maine Agriculture and Forest Experiment Station (Publication \# 3404) and the Center for Research on Sustainable 
Forests. We thank Amy Dowley and Cynthia Loftin of the University of Maine System for their assistance in working with Landsat 8 data, as well as the USGS for making satellite images available to the public. Historic aerial photos were provided by Dr. Chudamani Joshi, who originally obtained them from the Department of Forest Research and Survey, Nepal. This analysis would have not been possible without their assistance.

\section{LITERATURE CITED}

Achard, F., Eva, H. D., Stibig, H.-J., Mayaux, P., Gallego, J., Richards, T., \& Malingreau, J.-P. (2002). Determination of deforestation rates of the world's humid tropical forests. Science (New York, N.Y.), 297(5583), 999-1002.

Agrawal, A., \& Gupta, K. (2005). Decentralization and participation: the governance of common pool resources in Nepal’s Terai. World Development, 33(7), 1101-1114. http://doi.org/10.1016/j.worlddev.2005.04.009

Agrawal, A., \& Ostrom, E. (2001). Collective action, property rights, and decentralization in resource use in India and Nepal. Politics Society Vol. 29, No. 485, 29(4), 31. http://doi.org/10.1177/0032329201029004002

Agrawal, A., \& Ribot, J. C. (1999). Accountability in decentralization: a framework with South Asian and West African cases. The Journal of Developing Areas, 33(4), 473-502. 
Andersson, K. P., \& Ostrom, E. (2008). Analyzing decentralized resource regimes from a polycentric perspective. Policy Sciences, 41(1), 71-93.

http://doi.org/10.1007/s11077-007-9055-6

Bajracharya, D. (1983). Deforestation in the food/fuel context: historical and political perspectives from Nepal. Mountain Research and Development, 3(3), 227-240. http://doi.org/10.2307/3673017

Baral, N., \& Heinen, J. T. (2007). Resources use, conservation attitudes, management intervention and park-people relations in the Western Terai landscape of Nepal. Environmental Conservation, 34(1), 64.

http://doi.org/10.1017/S0376892907003670

Brower, B. (1991a). Crisis and conservation in Sagarmatha national park, Nepal. Society \& Natural Resources, 4(2), 151-163. http://doi.org/10.1080/08941929109380750

Brower, B. (1991b). Sherpa of Khumbu: people, livestock, and landscape (2nd ed.). Delhi: Oxford University Press.

Brower, B., \& Dennis, A. (1998). Grazing the forest, shaping the landscape? Continuing the debate about forest dynamics in Sagarmatha National Park. In K. Zimmerer \& K. Young (Eds.), Nature’s geography: new lessons for conservation in developing countries (pp. 184-208). Madison: University of Wisconsin Press.

Budhathoki, P. (2004). Linking communities with conservation in developing countries: buffer zone management initiatives in Nepal. Oryx, 38(3). http://doi.org/10.1017/S0030605304000584 
Chakraborty, R. N. (2001). Stability and outcomes of common property institutions in forestry: evidence from the Terai region of Nepal. Ecological Economics, 36(2), 341-353. http://doi.org/10.1016/S0921-8009(00)00237-8

FAO (Food and Agricultural Organization of the United Nations). (1979). Draft report of the Nepal community forestry development project preparatory mission. Washington D.C.

FECOFUN (Federation of Community Forest Users Nepal). (2014). Members. Retrieved October 1, 2014, from http://fecofun.org.np/members.php

Forestry Nepal. (2014). Master Plan for the Forestry Sector 1989. Retrieved January 27, 2015, from http://www.forestrynepal.org/wiki/102

Gautam, A. P. (2007). Group size, heterogeneity and collective action outcomes: evidence from community forestry in Nepal. International Journal of Sustainable Development \& World Ecology, 14(6), 574-583. http://doi.org/10.1080/13504500709469756

Gautam, A. P., \& Shivakoti, G. P. (2005). Conditions for successful local collective action in forestry: some evidence from the Hills of Nepal. Society \& Natural Resources, 18(2), 153-171. http://doi.org/10.1080/08941920590894534

Gautam, A. P., Shivakoti, G. P., \& Webb, E. L. (2004). A review of forest policies, institutions, and changes in the resource condition in Nepal. International Forestry Review, 6(2), 136-148. http://doi.org/10.1505/ifor.6.2.136.38397 
GoN (Government of Nepal). (2011). National population and housing census. Kathmandu.

Gurung, A., Bista, R., Karki, R., Shrestha, S., Uprety, D., \& Oh, S.-E. (2012).

Community-based forest management and its role in improving forest conditions in Nepal. Small-Scale Forestry, 12(3), 377-388. http://doi.org/10.1007/s11842012-9217-z

Guthman, J. (1997). Representing crisis: the theory of Himalayan environmental degradation and the project of development in post-Rana Nepal. Development and Change, 28, 45-69.

Hansen, M. C., Potapov, P. V, Moore, R., Hancher, M., Turubanova, S. A., Tyukavina, A., ... Townshend, J. R. G. (2013). High-resolution global maps of 21st-century forest cover change. Science (New York, N.Y.), 342(6160), 850-3.

Heinen, J. T., \& Mehta, J. N. (2000). Emerging issues in legal and procedural aspects of buffer zone management with case studies from Nepal. The Journal of Environment \& Development, 9(1), 45-67. http://doi.org/10.1177/107049650000900103

HMGN (His Majesty’s Government of Nepal). (1989). Historic aerial photographs. Kathmandu: Department of Forest Research and Survey, Ministry of Forests and Soil Conservation.

HMGN (His Majesty’s Government of Nepal). (1993). Forest Act 1993. Kathmandu. 
HMGN (His Majesty’s Government of Nepal). (1995). Forest Regulations 1995. Kathmandu.

HMGN (His Majesty’s Government of Nepal). (2001). National population and housing census. Kathmandu.

HMGN (His Majesty’s Government of Nepal). (2002). Nepal Biodiversity Strategy. Kathmandu.

HMGN (His Majesty’s Government of Nepal), ADB (Asian Development Bank), \& FINNIDA (Finnish International Development Agency). (1988). Master Plan for the Forestry Sector Nepal: main report. Kathmandu.

Jackson, W. J., \& Tamrakar, R. M. (1998). Land-use changes in two Middle Hills districts of Nepal. Mountain Research and Development, 18(3), 193-212. http://doi.org/10.2307/3674033

Johnson, T. (2012). Quantifying land cover changes using Landsat data and ArcGIS image analysis. Retrieved January 27, 2015, from http://igett.delmar.edu/Tjohn.html

Jones, S. (2007). Tigers, trees and Tharu: an analysis of community forestry in the buffer zone of the Royal Chitwan National Park, Nepal. Geoforum, 38(3), 558-575. http://doi.org/10.1016/j.geoforum.2006.10.010

Nagendra, H. (2007). Drivers of reforestation in human-dominated forests. Proceedings of the National Academy of Sciences of the United States of America, 104(39), 15218-23. http://doi.org/10.1073/pnas.0702319104 
Nagendra, H., Karmacharya, M., \& Karna, B. (2005). Evaluating forest management in Nepal: views across space and time. Ecology and Society, 10(1), 24.

Nagendra, H., Pareeth, S., Sharma, B., Schweik, C. M., \& Adhikari, K. R. (2007). Forest fragmentation and regrowth in an institutional mosaic of community, government and private ownership in Nepal. Landscape Ecology, 23(1), 41-54. http://doi.org/10.1007/s10980-007-9162-y

Nagendra, H., Tucker, C., Carlson, L., Southworth, J., Karmacharya, M., \& Karna, B. (2004). Monitoring parks through remote sensing: studies in Nepal and Honduras. Environmental Management, 34(5), 748-60. http://doi.org/10.1007/s00267-0040028-7

Nepal, S. K., \& Spiteri, A. (2011). Linking livelihoods and conservation: an examination of local residents’ perceived linkages between conservation and livelihood benefits around Nepal's Chitwan National Park. Environmental Management, 47(5), 727-738. http://doi.org/10.1007/s00267-011-9631-6

Nepal, S. K., \& Weber, K. E. (1995). A buffer zone for biodiversity conservation: viability of the concept in Nepal's Royal Chitwan National Park. Environmental Conservation, 21(4), 333-341. http://doi.org/10.1017/S0376892900033646

Ostrom, E. (1990). Governing the commons: the evolution of institutions for collective action. New York: Cambridge University Press.

Ostrom, E., Schroeder, L. D., \& Wynne, S. G. (1993). Institutional incentives and sustainable development: infrastructure policies in perspective. Boulder: Westview Press. 
Pandit, R., \& Bevilacqua, E. (2011). Forest users and environmental impacts of community forestry in the hills of Nepal. Forest Policy and Economics, 13(5), 345-352. http://doi.org/10.1016/j.forpol.2011.03.009

Panta, M., Kim, K., \& Joshi, C. (2008). Temporal mapping of deforestation and forest degradation in Nepal: Applications to forest conservation. Forest Ecology and Management, 256(9), 1587-1595. http://doi.org/10.1016/j.foreco.2008.07.023

Pravat, P. S. (2006). A history of forest politics in the Terai, Nepal: a case of equity or ecology? In ECPR Summer School on Environmental Politics. Staffordshire: Keele University School on Environmental Politics.

R Core Team. (2014). R: a language and environment for statistical computing. Vienna: R Foundation for Statistical Computing. Retrieved from http://www.r-project.org/

REDD (United Nations Collaborative Initiative on Reducing Emissions from Deforestation and Forest Degradation). (2014). REDD in Nepal. Retrieved October 1, 2014, from http://theredddesk.org/countries/nepal

Schreier, H., Brown, S., Schmidt, M., Shah, P., Shrestha, B., Nakarmi, G., ... Wymann, S. (1994). Gaining forests but losing ground: a GIS evaluation in a Himalayan watershed. Environmental Management, 18(1), 139-150. http://doi.org/10.1007/BF02393756

Schweik, C. M., Nagendra, H., \& Sinha, D. R. (2003). Using satellite imagery to locate innovative forest management practices in Nepal. AMBIO, 32(4), 312-319. http://doi.org/10.1579/0044-7447-32.4.312 
Shivakoti, G. P., \& Ostrom, E. (2002). Improving irrigation governance and management in Nepal. Oakland: ICS Press.

Spiteri, A., \& Nepal, S. K. (2008). Distributing conservation incentives in the buffer zone of Chitwan National Park, Nepal. Environmental Conservation, 35(1), 76-86. http://doi.org/10.1017/S0376892908004451

Stevens, S. (1983). Tourism and change in Khumbu (Bachelor's thesis). University of California, Berkeley.

Stevens, S. (1993). Claiming the high ground: Sherpas, subsistence, and environmental change in the Highest Himalaya. Berkeley: University of California Press.

Stevens, S. (1997). Consultation, co-management, and conflict in Sagarmatha (Mount Everest) National Park, Nepal. In S. Stevens (Ed.), Conservation through cultural survival: indigenous peoples and protected areas (pp. 63-97). Washington D.C.: Island Press.

Stevens, S. (2003). Tourism and deforestation in the Mt Everest region of Nepal. The Geographical Journal, 169(3), 255-277. http://doi.org/10.1111/1475-4959.00089

Stræde, S., \& Treue, T. (2006). Beyond buffer zone protection: a comparative study of park and buffer zone products’ importance to villagers living inside Royal Chitwan National Park and to villagers living in its buffer zone. Journal of Environmental Management, 78(3), 251-67. http://doi.org/10.1016/j.jenvman.2005.03.017 
UNESCO (United Nations Educational Scientific and Cultural Organization). (2013).

Chitwan National Park. Retrieved October 1, 2014, from http://whc.unesco.org/en/list/284

Upadhyay, S. (2012). Community based forest and livelihood management in Nepal. In D. Bollier \& S. Helfrich (Eds.), The wealth of the commons: a world beyond market and state. Amherst: Levellers Press. Retrieved from http://wealthofthecommons.org/essay/community-based-forest-and-livelihoodmanagement-nepal

USGS (United States Geological Survey). (2013). Using the USGS Landsat 8 product. Retrieved June 15, 2014, from http://landsat.usgs.gov/Landsat8_Using_Product.php

Virgo, K. J., \& Subba, K. J. (1994). Land-use change between 1978 and 1990 in Dhankuta District, Koshi Hills, Eastern Nepal. Mountain Research and Development, 14(2), 159-170. http://doi.org/10.2307/3673798

World Bank. (2013). World Bank indicators - Nepal - land use, trading economics. Retrieved June 15, 2014, from http://www.tradingeconomics.com/nepal/forestarea-percent-of-land-area-wb-data.html 


\section{CHAPTER 2}

\section{LINKING ATTITUDES, POLICY, AND FOREST COVER CHANGE IN BUFFER ZONE COMMUNITIES OF CHITWAN NATIONAL PARK, NEPAL}

\section{CHAPTER ABSTRACT}

Deforestation in Nepal threatens the functioning of complex social-ecological systems, including rural populations that depend on forests for subsistence, as well as Nepal's biodiversity and other ecosystem services. Nepal's forests are particularly important to the nation's poorest inhabitants, as many depend upon them for daily survival. Twothirds of Nepal's population relies on forests for sustenance, and these pressures are likely to increase in the future. This, coupled with high population densities and growth rates, highlights the importance of studying the relationship between human communities, forest cover trends through time, and forest management institutions. Here, we used surveys to explore how household attitudes associated with conservation-related behaviors in two rural communities - one that has experienced significant forest loss, the other forest gain - compare with forest cover trends as indicated by satellite-derived forest loss and regeneration estimates between 2005 and 2013. Results found a significant difference in attitudes in the two areas, perhaps contributing to and reacting from current forest conditions. In both study sites, participation in community forestry strengthened support for conservation, forest conservation-related attitudes aligned with forest cover trends, and a negative relationship was found between economic status and having supportive forest conservation-related attitudes. Additionally, on average, respondents 
were not satisfied with their district forest officers and did not feel that the current political climate in Nepal supported sustainable forestry. These findings are important as Nepal's Master Plan for the Forestry Sector has expired and the country is in the process of structuring a new Forestry Sector Strategy.

\section{INTRODUCTION}

After decades of deforestation in the latter part of the 20th Century, Nepal is now regarded by some as one of the world's leading examples of successful community-based forest management (Gautam et al., 2004). Nepal was one of the earliest adopters of community forestry in Asia (Pandit \& Bevilacqua, 2011a citing Arnold, 1992), and modern community-based forest management was formalized in the Master Plan for the Forestry Sector (MPFS) enacted in 1989, followed by related legislation in 1993 and 1995 (HMGN, 1993, 1995; HMGN, ADB, \& FINNIDA, 1988). In combination, the core goal of these three pieces of legislation was to grant limited management rights and authority to established community user groups to foster the rehabilitation of degraded forest parcels and better meet the needs of local people.

Community Forest User Groups (CFUGs) and Buffer Zone Community Forest User Groups (BZCFUGs; hereafter, “CFUGs” will be used interchangeably) were granted limited authority to manage forests in their communities. Before this, in 1957, Nepal nationalized all forests in the country to ensure centralized control over timber markets (Agrawal \& Ribot, 1999; Jones, 2007), but the Act undermined community-level management practices and significantly accelerated deforestation trends (Agrawal \& 
Ostrom, 2001). In addition, increased centralization and control over forest management created distrust between forest users and government forest-sector institutions - a condition that persists (Pandit \& Bevilacqua, 2011a; Pandit \& Bevilacqua, 2011b; Shrestha \& McManus, 2007).

Today, there are 1.7 million hectares of community forest - about $29 \%$ of all forests in Nepal. These forests support approximately 2.25 million households (GoN, 2014). Although community forestry has been highly influential in Nepal, there have been varying levels of success among communities in the last 25 years in terms of reversing historic deforestation trends, granting representation to various sociodemographic and ethnic groups, providing local employment, and promoting efficient bureaucratic structures (GoN, 2014).

A growing body of evidence - both empirical and anecdotal - suggests that modern forest-related policy changes have been effective in decentralizing management and reducing rates of forest loss (GoN, 2014; Chapter 1), and some studies suggest that community-based forest management has been effective in combatting forest degradation in Nepal over the last 25 years (Gautam, 2007; GoN, 2014; Nagendra, 2007; Nepal \& Spiteri, 2011; Spiteri \& Nepal, 2008; Stræde \& Treue, 2006).

Ostrom's (1990) seminal work examined how community-level self-governance of common pool resources (CPRs) can yield successful outcomes, especially as compared to centralized management institutions. In Nepal, as well as in many other parts of the world, her work also explored the complexities and fragility of management institutions, and what components of a CPR system are critical for it to function sustainably (e.g., 
Agrawal \& Ostrom, 2001; Agrawal \& Ostrom, 2008; Andersson \& Ostrom, 2008;

Ostrom et al., 1993; Shivakoti \& Ostrom, 2002).

Many studies have since examined the potential for successful self-governance of CPRs, particularly for forest resources in Nepal under varying social and biophysical conditions. These studies have reinforced the importance of Ostrom's design principles for managing CPRs (Ostrom, 1990), as well as common property institutions, group size, heterogeneity, and the presence of collective action (see, e.g., Agrawal \& Gupta, 2005; Gautam, 2007; Gautam \& Shivakoti, 2005; Chakraborty, 2001; Gurung et al., 2013; Nagendra et al., 2005; Shrestha \& McManus, 2007). Still needed, however, is a better understanding of how household attitudes associated with forest conservation-related behaviors aggregate to community-level decision-making and, ultimately, landscape outcomes.

Earlier work has shown that household surveys focused on community-based resource management have been an effective method in making connections between household perceptions and empirical trends (see, e.g., Jones, 2007; Mehta \& Kellert, 1998; Nepal \& Spiteri, 2011; Spiteri \& Nepal, 2008; Stræde \& Treue, 2006). Here, we describe the results of a household survey in two Village Development Committees (VDCs) located in the buffer zone of Chitwan National Park in southern Nepal (Figure 2.1). The VDCs were purposively selected based on a remote sensing analysis which identified buffer zone communities at two ends of a spectrum - one VDC experiencing high levels of forest loss between 2005 and 2013, the other VDC significant gains in forest cover (Chapter 1). Our first research objective sought to understand how household attitudes toward forest conservation-related behaviors correlated with empirical forest 
cover trends. Our second research objective explored which socio-demographic variables influenced supportive attitudes toward forest conservation-related behaviors.

\section{METHODS}

\section{Study Area}

Chitwan National Park (CNP), established in 1973, is a UNESCO-designated World Heritage Site. CNP is located close to the southern border of Nepal in the low-lying Terai region adjacent to India (Figure 2.1). CNP is considered subtropical lowland and is located at the foot of the Himalayan Mountains, adjacent to two rivers - the Narayani and the Rapti. The Park area extends over four administrative districts: Chitwan, Parsa, Nawalparasi, and Makwanpur. In addition to CNP, the Parsa Wildlife Reserve (PWR) is located to the east, and Beeshazar and its associated lakes are located to the north of the Park (UNESCO, 2013).

CNP and PWR together cover approximately 177,000 hectares of mostly forested land. CNP has a long history of human influence. When first established, it was named Royal Chitwan National Park, and was used by the royal family and other elites to hunt large animals such as Royal Bengal tigers (Panthera tigris), Asian one-horned rhinoceros (Rhinoceros unicornis) and Asian elephants (Elephas maximus). At the time, the Park and surrounding areas were fairly remote and inaccessible, and malaria was rampant. New roads were built in the 1950s and 1960s to improve access to the region, and forests were cleared to mitigate malaria and provide land for agricultural expansion and a growing population. 
Today there are 36 VDCs adjacent to CNP. The total population of these administrative units increased from 292,000 in 2001 (HMGN, 2001), to over 400,000 in 2011 (GoN, 2011). Note that CNP's official buffer zone does not include the entirety of the surrounding VDCs (Stræde \& Treue, 2006). For this study, the entire area of VDCs adjacent to the Park is considered, which includes areas beyond the official buffer zone of CNP. The annual per capita income in the Central Terai region is \$647 USD - slightly lower than the national per capita income of \$718 USD (Sharma et al., 2014). The average household size is 7.1 , with $48 \%$ of people being of working age, and $41 \%$ under the age of 15 (Stræde \& Treue, 2006, citing Banskota et al., 1996).

\section{Survey Design and Development}

We used a purposive sampling approach (Mahat, 2009; Tashakkori \& Teddie, 1998) to better understand how household attitudes toward forest conservation-related behaviors correlate with empirical forest cover trends in areas that are on opposite ends of the spectrum with regards to forest loss and gain in recent years. Previous remote sensing

work (Chapter 1) quantified the amount of forested land that had been deforested and regenerated within all 36 VDCs adjacent to CNP between the years 2005 and 2013. Two VDCs were purposively selected from this pool to meet these criteria - (1) Narayani, which had seen significant forest cover loss in recent years, and (2) Bachauli, which had seen significant forest regeneration (Figure 2.1).

Similarities between Bachauli and Narayani such as size, geographic location, and population allowed for comparison (Mahat, 2009). Narayani and Bachauli are approximately $17.7 \mathrm{~km}^{2}$ and $19.5 \mathrm{~km}^{2}$ in size, respectively. Bachauli's population rose approximately 23.5\% between 1991 and 2011, from 8,338 to 10,905; whereas the 
population in Narayani rose approximately 20\%, from 7,234 to 9,047 (HMGN, 1991; GoN, 2011). One difference is that Narayani is characterized by an agriculture-based economy, while Bachauli's economy relies heavily on ecotourism from CNP. In fact, the north entrance to CNP is located in the village of Sauraha, located within Bachauli.

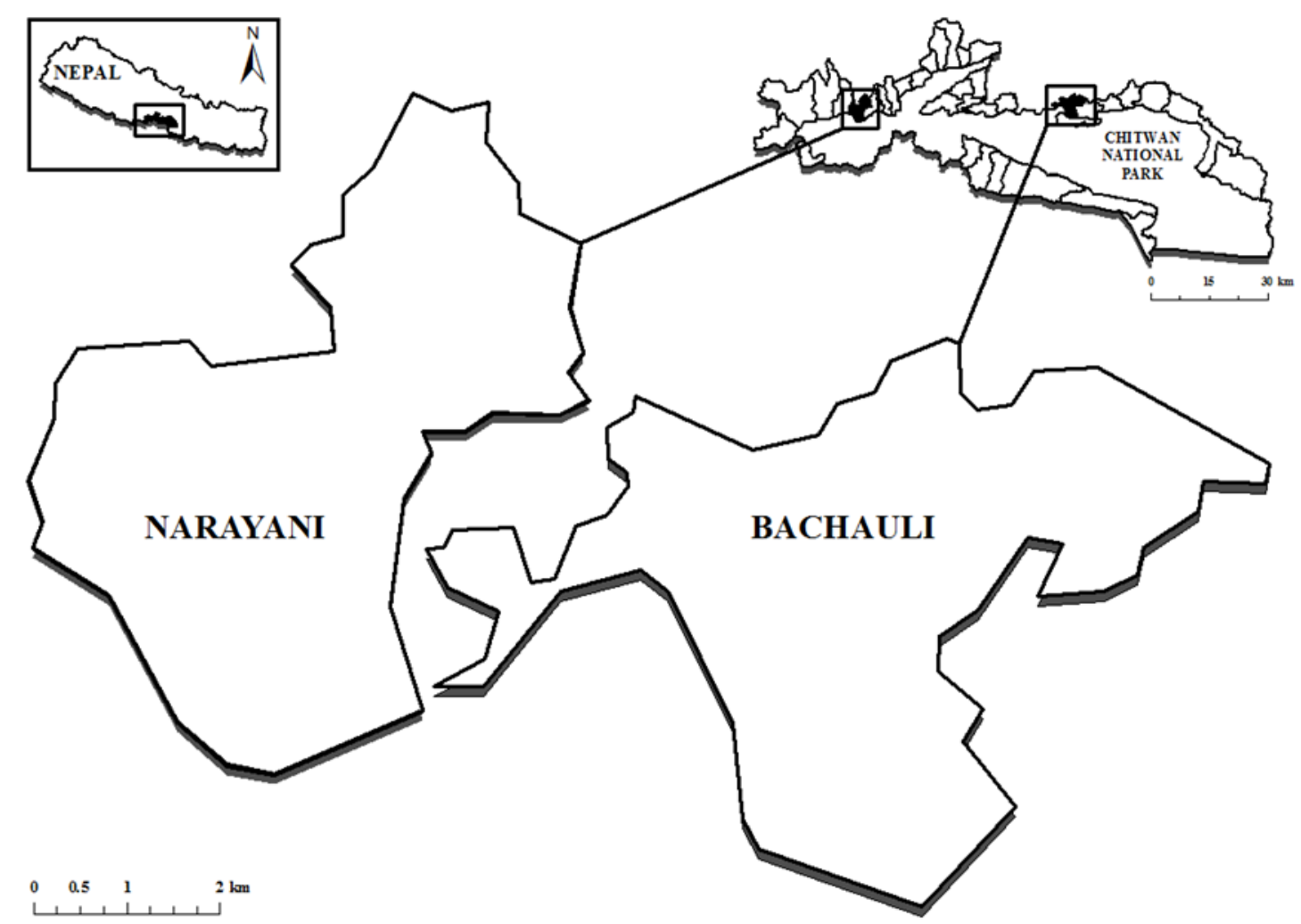

Figure 2.1. Location of Chitwan National Park and the VDCs of Bachauli and Narayani.

To better understand how household attitudes toward forest conservation-related behaviors correlate with empirical forest cover trends, we define attitudes which support forest conservation by considering a household's: (1) dependence on forests and perception of forest trends; (2) its willingness to support collective action and community 
forestry; (3) its willingness to support non-governmental organizations (NGOs) that promote forest conservation; (4) its willingness to adopt energy-efficient technologies which decrease pressure on forests; and (5) its willingness to support existing forestrelated institutions and policies.

Survey development was assisted by SeedTree ${ }^{1}$ (ST), a US-based NGO that has been engaged in reforestation and environmental education outreach in Nepal for the past two decades with a special emphasis on the Chitwan region. ST has developed innovative approaches to reforestation that combine community forestry with native/indigenous species protection to conserve and restore native trees, shrubs, and grasses in 23 of Nepal's 75 districts. ST has also worked to install improved cooking stoves and home biogas systems in many areas of Nepal.

The household survey used a five-point Likert scale, where 1 denoted "strongly agree” and 5 denoted "strongly disagree (De Vaus, 2002), as well as socio-demographic and economic questions. Additionally, two open-ended forest policy questions were included to provide information for further interpretation of the data (Oppenheim, 1992). After development, the survey was approved by the University of Maine Institutional Review Board (Application \#2014-02-14; Figure A.1). It was then translated into Nepali and tested on a small group of residents in Bachauli to assure that the translation was accurate, and the questions were understandable.

\footnotetext{
${ }^{1}$ For more information about SeedTree, visit: http://www.seedtree.org/
} 


\section{Data Collection}

A purposive survey sample was selected because of the absence of databases for households and household information such as addresses, telephone numbers, and household-level census data that would allow other types of sampling (Barber et al., 1997). We employed a two-stage approach to select survey participants. Individuals were selected in both VDCs using a network sampling approach (Sudman, 1988; Bernard, 2002). First, with the assistance of World Wildlife Fund-Nepal and SeedTree, village leaders in Bachauli and Narayani were contacted and asked to help in selecting individuals within their village who were willing and available to take the survey. These individuals then suggested others who would be willing to participate.

Additional respondents — as many as time and resources allowed — were selected using a random walk technique (Jones, 2007; Lyon, 2000). While not truly random, this is an efficient method for identifying individuals able and willing to participate in surveys in large, geographically remote areas (Jones, 2007). Additionally, some suggest that, although ideal, probability sampling methods are less-suited to small surveys (Benoit et al., 2005; Kish, 1965; Moser \& Kalton, 1971). Participation was not limited to any demographic, so long as the individual was an adult.

The survey was administered with the help of three translators, all fluent in Nepali as well as Tharu - a language endemic to the Terai region. Tharu is both the dominant ethnicity and language spoken in the area, making one-on-one translation essential for the completion of each survey. In total, 114 individuals were surveyed - 60 in Bachauli and 54 in Narayani. Each survey took approximately one hour to complete. The response rate was $100 \%$. 


\section{$\underline{\text { Statistical Analyses }}$}

Our first objective was to examine whether household attitudes toward forest conservation-related behaviors were consistent with empirical forest cover trends. Two analyses were performed to determine whether the overall survey results from Bachauli and Narayani were statistically different from one another - a critical step in determining whether the different forest cover trends in the two VDCs, as revealed through remote sensing in Chapter 1, were consistent with differences in local attitudes. All statistical tests were conducted using the 'Stats Package' in version 3.1.2 of the R Statistical Computing Software (R Core Team, 2014).

First, the total responses for each Likert scale item for both samples were compared against one another using a Pearson's Chi-squared test $(\alpha=0.05)$. There is considerable debate over whether Likert scale data should be analyzed as ordinal or interval. This is due to the fact that on a discrete 1-to-5 scale, a respondent is not allowed to respond with, for example, 1.5 or 2.7. For this reason, we used both parametric and non-parametric tests to examine whether there was a significant difference for each question between the two study areas. Both a Welch two-sample t-test and a MannWhitney-Wilcoxon test for distribution were used to compare the difference in each response $(\alpha=0.05)$. However, only the means and results of the t-tests are presented here because, although there is statistical value in checking for congruency between parametric and non-parametric tests, treating the data as interval allows for more powerful and sophisticated statistical analysis (Nepal \& Spiteri, 2011, citing De Vaus, 2002). 
In order to check for internal consistency of responses, Cronbach’s coefficient alpha was computed for all responses for Bachauli and Narayani (De Vaus, 2002). The scores were 0.69 and 0.71 , respectively, which both surpassed the minimum threshold requirement which must be met in order to confirm significant consistency (i.e., > 0.65) (DeVellis, 1991; Nepal \& Spiteri, 2011). The raw scores for each respondent for all questions was converted into an attitude index score by summing response values for all questions and then dividing by the number of questions (De Vaus, 2002). For Bachauli, the mean score was 1.90 (on a 1-to-5 scale, where 1 denotes "strongly agree” and 5 denotes "strongly disagree). For Narayani, the mean score was 2.48.

Our second objective was to examine which demographic and economic variables influence supportive attitudes toward forest conservation-related behaviors. Here, logistic regression using economic and socio-demographic variables was used to examine which variables explained the variation in attitudes. In order to use the attitude index scores as the dependent variable in the logistic regression models, they were first converted to a dichotomous dummy variable by separating the "supportive" scores from the "unsupportive" scores at the mean value (on 1-to-5 scale where 1 equals "strongly agree," indicating support for the questions asked). For Bachauli, scores below the mean were recoded as " 1 ” (supportive), with all other values as “ 0 ." The opposite was done for Narayani, recoding the values above the mean index score as "1" (unsupportive), with all other values as "0." This was done to examine which independent variables explained the variation in positive attitudes in Bachauli and negative attitudes in Narayani - a key question given the significant difference between the two areas in terms of both forest cover change over the last decade and overall survey responses (Chapter 1). 
In addition to the intercept coefficient, we also computed standard error, p-value, Wald statistic and goodness-of-fit values for each explanatory variable in the models to test the variable's individual and relative significance. The Wald statistic was calculated by dividing the intercept coefficient by the standard error coefficient and squaring the result. Hierarchical partitioning, using R2 as goodness-of-fit, was used to sum each variable's independent and joint contribution in explaining the variance of the response variable (Chevan \& Sutherland, 1991). This method is well-suited for applications in conservation and ecology because it takes into account all of the relationships between predictor variables and mitigates multicollinearity issues commonly encountered in multivariate regression analyses (Mac Nally, 2002).

\section{RESULTS}

\section{Socio-Demographic Characteristics of Respondents}

In Bachauli, $13.3 \%$ of respondents were male and $86.7 \%$ were female, while in Narayani, $31.5 \%$ of respondents were male and $68.5 \%$ were female. The mean household size was 7 persons in Bachauli and 6.3 in Narayani. The age of respondents ranged from 18 to 80 years, with an average age of 40 . Ages were classified into three categories: younger (16 to 35), middle-aged (36 to 55), and older (56+) (Mehta \& Heinen, 2001). For Bachauli and Narayani, respectively, $38.3 \%$ and $46.3 \%$ were younger, $45 \%$ and $44.4 \%$ were middle-aged, and $16.7 \%$ and $9.3 \%$ were older. In total, $67.4 \%$ of respondents reported being a member of a Community Forest User Group (CFUG) in their community, with 53.3\% in Bachauli and 81.5\% in Narayani. Respondents were asked to state whether or not they were are able to support their household's livelihood on a daily basis. This 
served as a proxy for “wealthy” or "poor” (Mehta \& Heinen, 2001; Spiteri \& Nepal, 2008). In Bachauli and Narayani, 25\% and 66.7\%, respectively, were categorized as wealthy, with $75 \%$ and $33.3 \%$ categorized as poor.

Because the average annual income is so low in this region of Nepal, two additional economic variables were collected - the amount of land and livestock each respondent owned. Nepali standards of area measurement were used in the field and later converted to hectares with the help of local translators. The average amount of land owned in Bachauli and Narayani was 8.6 ha and 9.1 ha, respectively. The survey asked each person to include head counts for each type of livestock they owned. This number was re-scaled using the Tropical Livestock Unit (TLU) measurement system developed by the Food and Agricultural Organization of the United Nations to create a continuous, rather than categorical, variable (FAO, 2003). The TLU system administers a score for each type of livestock based on each country's continent, with Asian values ranging from 0.01 for a chicken, to 0.50 for a cow or buffalo. TLU scores were summed and ranged from 0 to 6.5 in Bachauli and 0 to 5 in Narayani. Households in Bachauli reported owning more livestock compared to Narayani, i.e., a livestock score of 1.12 compared to 0.72 .

The use of both fuel-efficient stoves and household biogas has been influential drivers in the reduction of forest loss in Nepal, and the adoption of both has consistently risen over the last 25 years. In Bachauli and Narayani, 25\% and 51.9\% of respondents indicated that they use fuel-efficient stoves, while $46.7 \%$ and $20.4 \%$ use home biogas energy systems, respectively. Finally, level of education was collected for each respondent with the choices of "none," "primary," "lower secondary," "secondary," and 
"university." 18\% of respondents in Narayani and 31.7\% of those in Bachauli had no education, while close to half of respondents ( $40.7 \%$ and $46.7 \%$, respectively) had a primary education, $11.1 \%$ and $0 \%$ had a lower secondary education, $24.1 \%$ and $3.3 \%$ had a secondary education, and $5.6 \%$ and $16.7 \%$ had attended a university.

Ethnicity was broken-down into three categories: (1) Tharu, the dominant ethnicity; (2) Hindu higher castes such as Brahmin and Chhetri; and (3) others, including castes such as Magar, Newar, Kumal and Kurmi (Sah \& Heinen 2001 citing Bista 1987). Overall, one-third of all respondents belonged to "other” castes, 63.2\% were Tharu, and very few - only 3.5\% - belonged to a higher class.

\section{$\underline{\text { Distribution and Difference in Attitudes between Bachauli and Narayani }}$}

For all Likert questions, there was a significant difference between the two VDCs ( $p<$ 0.001) (Table 2.1). For both parametric and non-parametric tests, a significant difference ( $p=<0.05$ ) was found between the two VDCs for every question except for Question 4, "I am satisfied with the current condition of forests in my community" (see Table 2.2). In addition, the mean responses for all but two questions were more supportive of behaviors that support forest conservation in Bachauli than Narayani (i.e., values closer to 1 on a 1to-5 scale). The two questions that were less supportive in Bachauli than Narayani were Questions 5 and 8 (see Table 2.2) - "I am actively involved in the operation and effectiveness of the Community Forest User Group in my area," and "It is important that all community members receive benefits from the way that forests are managed in my community.” In Table 2.2, the survey questions and results are categorized into five separate classes, representing the five concepts which were used to define attitudes hypothesized to support forest conservation. 
Informal interviews with respondents, combined with responses provided on the optional open-ended survey questions, contribute additional insight. For example, in Narayani, community forests reportedly provide habitat for CNP wildlife such as the onehorned rhinoceros, which lives and breeds in forests along the Narayani River. Without forests, rhinos and other CNP wildlife may feed and take refuge in croplands. The people of Narayani hope to attract more ecotourists in the future, and projects are underway to expand tourism infrastructure such as picnic areas and lodging facilities. In Bachauli, revenue from some community forests was being used for development projects such as constructing a new women's center, which was to offer free literacy classes. In Bachauli, CFUGs were almost entirely comprised of poorer women, and were viewed as a positive opportunity to incorporate women in community responsibilities and decision making. However, of the two CFUGs we met with in Narayani, one was comprised of a large group of mostly women, while the second — which oversees and manages considerably more forested land in the area — was comprised entirely of a small group of men.

Table 2.1. Distribution of responses to all survey questions in Bachauli and Narayani.

Likert scale responses on 1-to-5 scale

\begin{tabular}{lllllll} 
& $\begin{array}{l}\text { (1) Strongly } \\
\text { Agree }\end{array}$ & (2) Agree & (3) Neutral & (4) Disagree & $\begin{array}{l}\text { (5) Strongly } \\
\text { Disagree }\end{array}$ & Total obs. \\
\hline Bachauli & $396(44.0 \%)$ & $321(35.7 \%)$ & $109(12.1 \%)$ & $35(3.9 \%)$ & $39(4.3 \%)$ & 900 \\
Narayani & $188(23.2 \%)$ & $321(39.6 \%)$ & $114(14.1 \%)$ & $95(11.7 \%)$ & $92(11.4 \%)$ & 810 \\
Total obs. & 584 & 642 & 223 & 130 & 131 & 1,710 \\
\hline
\end{tabular}

Chi square $=118.922, n=1,710, d f=4, \alpha=0.05$, $p$-value $<0.001$ 
Table 2.2. Mean survey responses and t-test results for Bachauli and Narayani.

\begin{tabular}{|c|c|c|c|c|c|c|c|}
\hline \multirow{2}{*}{ Questions on 1-to-5 scale (1= strongly agree) ${ }^{\mathrm{a}}$} & \multicolumn{3}{|c|}{ Bachauli } & \multicolumn{3}{|c|}{ Narayani } & \multirow[b]{2}{*}{ WT $p$} \\
\hline & $\overline{\mathrm{x}}$ & SE & $\mathrm{G} \overline{\mathrm{x}}$ & $\overline{\mathrm{x}}$ & $\mathrm{SE}$ & $\mathrm{G} \overline{\mathrm{x}}$ & \\
\hline $\begin{array}{l}\text { Household need for forests and perception of forest } \\
\text { trends }\end{array}$ & & & 1.82 & & & 2.9 & \\
\hline $\begin{array}{l}\text { 1. My household relies on local forests for } \\
\text { fuelwood }\end{array}$ & 1.86 & 0.89 & & 3.31 & 1.12 & & $<0.001$ \\
\hline $\begin{array}{l}\text { 2. My household relies on local forests for fodder } \\
\text { for livestock }\end{array}$ & 1.91 & 0.92 & & 4.13 & 1.28 & & $<0.001$ \\
\hline $\begin{array}{l}\text { 3. Forests in my community have improved in } \\
\text { recent years }\end{array}$ & 1.53 & 0.87 & & 2.00 & 0.75 & & 0.002 \\
\hline $\begin{array}{l}\text { 4. I am satisfied with the current condition of } \\
\text { forests in my community }\end{array}$ & 1.96 & 0.41 & & 2.16 & 0.79 & & 0.24 \\
\hline $\begin{array}{l}\text { Willingness to support collective action and } \\
\text { community forestry }\end{array}$ & & & 1.65 & & & 1.73 & \\
\hline $\begin{array}{l}\text { 5. I am actively involved in the operation and } \\
\text { effectiveness of the Community Forest User Group } \\
\text { (CFUG) in my area }\end{array}$ & 1.75 & 0.89 & & 1.20 & 0.45 & & $<0.001$ \\
\hline $\begin{array}{l}\text { 6. Efforts by our CFUG have improved the } \\
\text { condition of forests in my community }\end{array}$ & 1.61 & 0.76 & & 2.48 & 0.81 & & $<0.001$ \\
\hline $\begin{array}{l}\text { 7. Forest condition in my community has improved } \\
\text { because of community-wide cooperation }\end{array}$ & 1.66 & 0.89 & & 1.96 & 0.67 & & 0.046 \\
\hline $\begin{array}{l}\text { 8. It is important that all community members } \\
\text { receive benefits from the way that forests are } \\
\text { managed in my community }\end{array}$ & 1.56 & 0.69 & & 1.27 & 0.68 & & 0.027 \\
\hline $\begin{array}{l}\text { Willingness to work with NGOs that promote forest } \\
\text { conservation }\end{array}$ & & & 1.54 & & & 2.24 & \\
\hline $\begin{array}{l}\text { 9. Non-governmental organizations (NGOs) that } \\
\text { promote reforestation efforts have improved } \\
\text { forests in my community }\end{array}$ & 1.63 & 0.93 & & 2.55 & 0.94 & & $<0.001$ \\
\hline $\begin{array}{l}\text { 10. I am willing to work with and receive help } \\
\text { from NGOs to improve forest conditions in my } \\
\text { community }\end{array}$ & 1.45 & 0.74 & & 1.92 & 0.77 & & 0.001 \\
\hline $\begin{array}{l}\text { Supportive of forest-related institutions and policies } \\
\text { in place }\end{array}$ & & & 2.81 & & & 3.52 & \\
\hline $\begin{array}{l}\text { 11. I am satisfied with current forest policies in } \\
\text { Nepal }\end{array}$ & 2.08 & 0.92 & & 3.11 & 1.23 & & $<0.001$ \\
\hline 12. I am satisfied with my District Forest Officers & 3.05 & 1.12 & & 3.57 & 0.98 & & 0.009 \\
\hline $\begin{array}{l}\text { 13. Nepal’s political climate today supports } \\
\text { sustainable forest management }\end{array}$ & 3.31 & 1.26 & & 3.88 & 1.36 & & 0.022 \\
\hline Supportive of the use of energy-efficient technologies & & & 1.46 & & & 1.83 & \\
\hline $\begin{array}{l}\text { 14. Fuel-efficient stoves are important in } \\
\text { sustaining forests in my community }\end{array}$ & 1.46 & 0.65 & & 1.77 & 0.63 & & 0.011 \\
\hline $\begin{array}{l}\text { 15. Household biogas is important in sustaining } \\
\text { forests in my community }\end{array}$ & 1.45 & 0.64 & & 1.88 & 0.81 & & 0.002 \\
\hline
\end{tabular}




\section{Logistic Regression Analysis}

Logistic regression was used to determine which socio-demographic variables influenced supportive attitudes toward forest conservation-related behavior. The results for Bachauli and Narayani are shown in Tables 2.3 and 2.4, respectively. In Bachauli, having supportive attitudes toward forest conservation was positively correlated with participating in a CFUG $(p=0.01)$, and household size $(p=0.03)$. Supportive attitudes were negatively correlated with being wealthy $(p=0.03)$. A second economic indicator, the amount of livestock owned, was also found to have a negative correlation with supportive attitudes toward forest conservation (i.e., more livestock, less supportive of conservation). In Narayani, being wealthy was also found to be negatively correlated with supportive attitudes toward forest conservation $(p=0.02)$, while the other two economic indicators - hectares of land owned and amount of livestock owned - were positively correlated ( $p=0.04$ and $p=0.02$, respectively).

Table 2.3. Logistic regression examining correlation between socio-demographic variables and positive attitudes toward forest conservation-related behavior in Bachauli. ${ }^{\text {a }}$

\begin{tabular}{llllll}
\hline Variable & $\mathrm{B}$ & $\mathrm{SE}$ & Wald & $p$ & $R$ \\
\hline Age & 0.05 & 0.03 & 2.78 & 0.13 & $<0.001$ \\
Gender (female) & 2.53 & 1.44 & 3.09 & 0.07 & 0.09 \\
CFUG member (yes) & 2.62 & 1.06 & 6.11 & $0.01^{*}$ & 0.21 \\
Economic status (wealthy) & -1.96 & 0.95 & 4.26 & $0.03^{*}$ & 0.11 \\
No. of persons in household & 0.42 & 0.20 & 4.39 & $0.03^{*}$ & 0.06 \\
Hectares of land owned & 0.006 & 0.01 & 1.44 & 0.26 & 0.1 \\
Livestock owned & -1.16 & 0.51 & 5.17 & $0.02^{*}$ & 0.005 \\
Education & 0.41 & 0.39 & 1.11 & 0.30 & 0.001 \\
Caste (Tharu) & 1.33 & 0.90 & 2.18 & 0.14 & 0.05 \\
\hline
\end{tabular}

${ }^{\mathrm{a}} \mathrm{N}=60, \mathrm{~B}=$ logistic regression coefficient, $\mathrm{SE}=$ standard error, Wald $=$ Wald statistic. $p=$ significance, $R$ $=\mathrm{R}^{2}$ statistic (the sum of the variable's independent and joint contribution in explaining the variance of the dependent variable). 
Table 2.4. Logistic regression examining correlation between socio-demographic variables and negative attitudes toward forest conservation-related behavior in Narayani. ${ }^{\mathrm{a}}$

\begin{tabular}{llllll}
\hline Variable & $\mathrm{B}$ & $\mathrm{SE}$ & Wald & $p$ & $R$ \\
\hline Age & -0.008 & 0.03 & 0.07 & 0.81 & 0.01 \\
Gender (female) & 0.45 & 1.07 & 0.18 & 0.67 & 0.06 \\
CFUG member (yes) & -1.57 & 1.10 & 2.04 & 0.15 & 0.01 \\
Economic status (wealthy) & 2.26 & 1.01 & 5.01 & $0.02^{*}$ & 0.08 \\
No. of persons in household & 0.13 & 0.15 & 0.75 & 0.37 & 0.001 \\
Hectares of land owned & -0.005 & 0.002 & 6.25 & $0.04^{*}$ & 0.05 \\
Livestock owned & -0.94 & 0.40 & 5.52 & $0.02^{*}$ & 0.05 \\
Education & 0.66 & 0.46 & 2.06 & 0.15 & 0.01 \\
Caste (Tharu) & 1.23 & 0.77 & 2.55 & 0.11 & 0.01 \\
\hline
\end{tabular}

${ }^{\mathrm{a}} \mathrm{N}=54, \mathrm{~B}=$ logistic regression coefficient, $\mathrm{SE}=$ standard error, Wald = Wald statistic. $p=$ significance, $R$ $=\mathrm{R}^{2}$ statistic (the sum of the variable's independent and joint contribution in explaining the variance of the dependent variable).

\section{DISCUSSION}

Community-based forest management has been influential in reducing forest degradation rates and conserving local biodiversity in many regions of the globe. Despite this general finding, household characteristics, attitudes, and socio-demographic variables of stakeholders involved have not been closely examined in community forestry systems in Nepal (Acharya et al., 2004; Adhikari et al., 2004). Because community forestry has been established in Nepal for a relatively longer time than most countries, it provides an ideal location to study household perceptions (Adhikari et al., 2004). Our research sought to explore how household attitudes toward forest conservation-related behaviors correlated with empirical forest cover trends. We also sought to better understand the sociodemographic variables that influence supportive attitudes toward forest conservationrelated behaviors in our two study locations. 
Supportive attitudes included having a need for forests in their community, being cognizant of current forest conditions, supporting their local CFUG, being willing to work with NGOs that promote sustainable forest practices, supporting forest-related policies and management institutions in Nepal, and recognizing the importance of energy-efficient technologies such as fuel-efficient stoves and biogas in reducing forest degradation.

Of the 36 VDCs adjacent to CNP, Bachauli and Narayani are on opposite ends of the spectrum in terms of reversing forest trends between 2005 and 2013. Bachauli has not just ceased the rapid rate of forest loss that it experienced prior to 2005, but in the last decade it has reversed it to a rate of significant regrowth (Chapter 1). The opposite is true for Narayani. The relative success of other communities in Nepal in terms of forest conservation and community forestry varies as well (see, e.g., Gautam \& Shivakoti, 2005). A clear difference was found between the overall attitudes of respondents toward forest conservation in Bachauli and Narayani, and it appears that attitudes between the areas of interest reflect forest cover trends - i.e., they are distinctly different, with attitudes in Bachauli being more supportive of forest conservation.

Although the overall differences between the two VDCs, and between almost every question, were significantly different, many interesting connections can be drawn between Bachauli and Narayani. Both populations reported being unsatisfied with their district forest officers (DFOs), and both expressed that Nepal's current political climate does not support sustainable forest management. Iversen et al. (2006) conducted a study about the high-value Sal (Shorea robusta) forests and institutions in place regarding community forest user groups in the Terai region and found that "Terai user groups face 
serious challenges in terms of monitoring the actions of office-holders," and that "the local leverage of the DFO is strong and may create problems” (p. 104).

Interestingly, the only question on the survey which did not show a significant difference between the two communities was "I am satisfied with the current condition of forests in my community” (Question 4 in Table 2.2). Although Narayani has seen significant loss in total forest cover between 2005 and 2013 (Chapter 1), respondents did not view these trends as negative. After all, Narayani’s economy is agriculture-based, and hence land use may be prioritized for crops - not community forests. However positive this might be for the people of Narayani, it raises a challenge for future forest conservation efforts in Nepal. Indeed, as population rises, there will likely be increased pressure to convert forests to agricultural uses.

Additionally, there was a large difference in mean responses between Narayani and Bachauli for Question 11: "I am satisfied with current forest policies in Nepal” (see Table 2.2). Respondents from Bachauli were somewhat satisfied, while those in Narayani were somewhat dissatisfied. The questions grouped under "Household need for forests and perception of forest trends” had overall large differences between Bachauli and Narayani, with Bachauli having strongly more supportive responses than Narayani for Questions 1 through 3 (see Table 2.2). Three conclusions can be inferred from these data. First, the perception of forest improvement in recent years reinforces the results of previous remote sensing results (Chapter 1). That is, Bachauli has seen dramatic improvement in terms of forest cover in recent years, and Narayani has seen much loss, both of which are accurately reflected in responses to Question 3: "Forests in my community have improved in recent years.” Second, households in Bachauli are 
significantly more reliant on forests for fuelwood in their community. Third, households in Bachauli are significantly more reliant on forests for livestock fodder in their community (Table 2.2). These results can perhaps be explained in part by the percentage of respondents in both Bachauli and Narayani who use energy-efficient technologies. For example, respondents in Bachauli owned significantly more livestock and used home biogas systems more often than those in Narayani, which reinforces Bachauli's reported reliance on community forests for fodder. Households with livestock, such as in Bachauli, would logically use biogas more, because they have a more readily-available supply of animal waste that can be used to fuel the units and generate energy.

In Bachauli, the strongest positive correlation in the logistic regression analysis was found between being a member of a CFUG and having supportive attitudes toward forest conservation (Table 2.3). Although intuitive, this finding supports the hypothesis that community forestry in Nepal has had a positive influence in reversing forest loss over time. Being wealthy and owning more livestock was shown to negatively affect attitudes in Bachauli, and poorer households were more supportive of forest conservation. In Narayani, the same was true for wealth - i.e., being wealthy was correlated with lesssupportive attitudes toward forest conservation. However, the amount of land and livestock a Narayani household owns was positively correlated with having supportive attitudes.

It is difficult to interpret this difference between the two communities in this regard, although it is perhaps influenced by Narayani’s primarily agricultural economy. Adhikari et al. (2004) examined a pattern linking household resources such as land and livestock to dependence on community forests and found that farming households 
required substantially more tree and grass fodder - noted as an important product of community forests by Thomas (2008) - for their livestock than those without land or livestock. Also, those with farms and livestock in Narayani are the working class of the area, and although most people are farmers, one-third of respondents reported not being able to support their family's livelihood on a daily basis (Table 2.4). For comparison, $75 \%$ of Bachauli respondents also reported not being able to support their family on a daily basis. Although farming households rely on community forests more than nonfarmers, the poorest households are unable to afford sufficient land and livestock and therefore require less fodder and other forest products (Adhikari et al., 2004). These results suggest that households with more livestock in Bachauli, and households with agricultural lands in Narayani, are both reliant on forests in their community to support their livelihoods.

Informal interviews with respondents, combined with responses provided on the optional open-ended survey questions, describe a desire for forests in both communities to provide habitat for CNP animals in order to mitigate crop destruction by wildlife. Perhaps for this reason, farming households that own land and livestock might value forest conservation more than households that do not. Karanth and Nepal (2012) found that all survey respondents supported tourism in CNP, and 97\% expressed a supportive attitude of the Park. There is also a consensus in both Bachauli and Narayani that forests support ecotourism. Forests provide habitat for CNP's endangered wildlife, which is primarily what attracts tourists to the area, as well as aesthetics and shade for lodging facilities and picnic areas. 
In Bachauli, CFUGs were almost entirely comprised of poorer women, and were viewed as a positive opportunity to incorporate women in community responsibilities and decision making. This is a progressive exception to the norm, as a recent REDD study by Khadka et al. (2014) found that women only represent about 15\% of leadership positions in CFUGs studied in Nepal. While positive, barriers still exist in the decision-making processes of CFUGs for marginalized groups such as women (Adhikari et al., 2014). Although women participate in most forest management tasks, they are typically not included in decision-making processes (Khadka, 2010; Poudel et al., 2014).

Community forestry in Nepal has the potential to contribute to social capital in many forms such as new schools, academic scholarships for children from marginalized groups, and new roads (Gautam, 2009; Pokharel et al., 2012). In Bachauli, revenue from some community forests was being used for development projects such as constructing a new women's center, which was to offer free literacy classes. One of the two CFUGs that were visited in Narayani, however, was comprised of a handful of wealthier men and appeared to poorly represent the overall demographics of the area — a problem viewed by some studies as widespread in Nepal (see, e.g., Chhetri et al., 2012; Lund et al., 2014; Malla et al., 2003).

\section{CONCLUSION}

Although this study was conducted in a small area of Nepal, it examined communities experiencing some of the highest and lowest rates of forest degradation in the area. Our comparison provides insight on the current status of decentralized, community-based 
forest management in the country, and offers specific policy recommendations. These findings are especially important as Nepal's Master Plan for the Forestry Sector expired in 2011, and the country is in the process of developing a new Forestry Sector Strategy. In addition to our findings, the Review Summary Report (MFSC) of the MPFS, released in April 2014, discusses many areas where the MPFS has struggled, many of which such as a lack of marginalized population inclusion and inefficient government forestry sector institutions — reinforce our findings.

Our results suggest several forest policy recommendations. First, we found significant differences in attitudes in the two communities we studied, perhaps contributing and responding to their respective current forest condition and trends. Attitudes toward forest conservation parallel empirical forest cover trends in both Narayani and Bachauli, with generally supportive attitudes toward forest conservation reported from Bachauli, and less-supportive attitudes from Narayani. This gives insight into how to best target populations who might be supportive of efforts to improve forest conditions by better understanding how attitudes correspond with empirical forest cover trends.

We found that attitudes which support forest conservation are correlated with wealth, with poorer households in both study sites being more supportive of forest conservation. Although the MFSC report states the MPFS has "enhanced the livelihoods of the rural people who have been involved whilst giving special focus to the needs of poor and disadvantaged households," it also cautions that the policy has "failed to have significant impacts on rural employment and the local economy," noting that “a clear policy for the allocation of national forest to the various community-based forest 
management regimes is lacking - especially for the Terai” region - i.e., the area of our study (GoN, 2014 p. 2).

Decentralized, community-based forest management conceptually allows traditionally underrepresented populations to participate in the responsibility, social benefits, and revenue that come with managing forests. However, underrepresented populations are often marginalized within community-based forest management in Nepal (McDougall et al., 2013). The MFSC report sheds further light on the lack of progress toward social inclusion and poverty alleviation, stating that stakeholders

such as women, poor people and disadvantaged groups (including marginalized indigenous communities), although usually nominally represented in various decision-making forums, have little genuine power and voice and there is still a tendency towards unilateral decisions and lack of transparency on the part of government and more powerful civil society actors (GoN, 2014 p. 20).

Indeed, Pandit and Bevilacqua (2011b) found that the wealthy group in their study (i.e., elite castes) generally perceived user participation in CFUG activities to be more balanced and evenly-distributed than women and other marginalized groups. KC et al. (2014) found that in recent years, community forestry in Nepal has shifted from providing forest products for community use to maximizing revenues, which is happening through elite dominance and marginalization of poorer community members 
and castes. Furthermore, when marginalized people are included in community forestry tasks, they are typically attending meetings and doing volunteer jobs — which become costly to the individual — such as patrolling the forest (Pokharel et al., 2012).

It is concerning that even in Bachauli - where forest conditions have improved and the consensus among respondents is generally supportive of forest conservation there is dissatisfaction with district forest officers and a general belief that Nepal's political climate today does not support sustainable forest management. These views were shared in Narayani. Informal interviews and discussions revealed a general distrust toward national-level governmental institutions regulating community forestry. The MFSC report reinforces this perception by stating that, "The legal autonomy of forestry groups has been eroded by a series of administrative orders, circulars and other decisions that have increased the transaction costs of better forest utilization and has hindered the growth of forest based enterprises” (GoN, 2014 p. 2).

Here, we suggest two areas of need to be considered as Nepal develops its new Forestry Sector Strategy. The first is to ensure increased distribution of rights, responsibilities, and revenue for poorer, underrepresented populations. Participatory forest management has proven to be effective in reducing forest loss in Nepal, and it is imperative that women, the poor, and other disadvantaged groups share in these responsibilities and benefits. The second is for government institutions and representatives to become more transparent, consistent, and considerate in their management practices and relationships with communities and CFUGs. In Nepal, "government forestry sector institutions are viewed as archaic and largely ineffective in meeting the needs of a changing society” (GoN, 2014 p. 7). Although equal participation 
alone is not a panacea (KC et al., 2014 citing Cohen \& Uphoff, 1980), the state of forests in Nepal can only improve if better relationships are built between all stakeholders.

\section{ACKNOWLEDGMENTS}

This research was supported by National Science Foundation award EPS-0904155 to Maine EPSCoR Sustainability Solutions Initiative at the University of Maine, McIntireStennis grant number MEO-M-700510-13, and the USDA National Institute of Food and Agriculture. Additional support was provided by the Maine Agriculture and Forestry Experimental Station (Publication \# 3405) and the Center for Research on Sustainable

Forests. We thank for their assistance Dr. Ambika Gautam of Kathmandu Forestry College, Abdul Ansari of the World Wildlife Fund-Nepal, Carol Kinsey of SeedTree, Baburam Vishowakarma, Satya-Narayan Chaudhary, Yubaraj Ghatane, and Beeju Poudyal.

\section{LITERATURE CITED}

Acharya, U., Petheram, R. J., \& Reid, R. (2004). Concepts and perceptions of biodiversity in community forestry, Nepal. Small-Scale Forest Economics, Management and Policy, 3(3), 401-410. http://doi.org/10.1007/s11842-004-00288

Adhikari, B., Di Falco, S., \& Lovett, J. C. (2004). Household characteristics and forest dependency: Evidence from common property forest management in Nepal. 
Ecological Economics, 48(2), 245-257.

http://doi.org/10.1016/j.ecolecon.2003.08.008

Agrawal, A., \& Gupta, K. (2005). Decentralization and participation: the governance of common pool resources in Nepal's Terai. World Development, 33(7), 1101-1114. http://doi.org/10.1016/j.worlddev.2005.04.009

Agrawal, A., \& Ostrom, E. (2001). Collective action, property rights, and decentralization in resource use in India and Nepal. Politics Society Vol. 29, No. 485, 29(4), 31. http://doi.org/10.1177/0032329201029004002

Agrawal, A., \& Ostrom, E. (2008). Decentralization and community-based forestry: learning from experience. In E. L. Webb \& G. P. Shivakoti (Eds.), Decentralization, forests and rural communities: policy outcomes in Southeast Asia (pp. 44-67). New Delhi, India: Sage Publications.

Agrawal, A., \& Ribot, J. C. (1999). Accountability in decentralization: a framework with South Asian and West African cases. The Journal of Developing Areas, 33(4), 473-502.

Andersson, K. P., \& Ostrom, E. (2008). Analyzing decentralized resource regimes from a polycentric perspective. Policy Sciences, 41(1), 71-93. http://doi.org/10.1007/s11077-007-9055-6

Arnold, J. E. M. (1992). Community forestry ten years in review. Rome. 
Barber, J. S., Shivakoti, G. P., Axinn, W. G., \& Gajurel, K. (1997). Sampling strategies for rural settings: a detailed example from Chitwan Valley Family Study, Nepal. Nepal Population Journal, 6(5), 193-203.

Benoit, C., Jansson, M., Millar, A., \& Phillips, R. (2005). Community-academic research on hard-to-reach populations: benefits and challenges. Qualitative Health Research, 15(2), 263-282. http://doi.org/10.1177/1049732304267752

Bernard, R. H. (2002). Research methods in anthropology: qualitative and quantitative methods (3rd ed.). Walnut Creek: AltaMira Press.

Bista, D. B. (1987). People of Nepal (5th ed.). Kathmandu: Ratna Pustak Bhandar.

Chakraborty, R. N. (2001). Stability and outcomes of common property institutions in forestry: evidence from the Terai region of Nepal. Ecological Economics, 36(2), 341-353. http://doi.org/10.1016/S0921-8009(00)00237-8

Chevan, A., \& Sutherland, M. (1991). Hierarchical parititioning. The American Statistician, 45(2), 90-96.

Chhetri, B. B. K., Lund, J. F., \& Nielsen, Ø. J. (2012). The public finance potential of community forestry in Nepal. Ecological Economics, 73, 113-121. http://doi.org/10.1016/j.ecolecon.2011.09.023

Cohen, J. M., \& Uphoff, N. T. (1980). Participation’s place in rural development: seeking clarity through specificity. World Development, 8(3), 213-235. http://doi.org/10.1016/0305-750X(80)90011-X 
De Vaus, D. (2002). Surveys in social research (5th ed.). London: Routledge. http://doi.org/10.2307/2071069

DeVellis, R. F. (1991). Scale development: theory and applications. Newbury Park: Sage.

FAO (Food and Agricultural Organization of the United Nations). (2003). Compendium of agricultural-environmental indicators: 1989-91 to 2000 (p. 36). Rome. Retrieved from http://www.fao.org/fileadmin/templates/ess/documents/other_statistics/compendiu m/agr_env_indic.pdf

Gautam, A. P. (2007). Group size, heterogeneity and collective action outcomes: evidence from community forestry in Nepal. International Journal of Sustainable Development \& World Ecology, 14(6), 574-583. http://doi.org/10.1080/13504500709469756

Gautam, A. P. (2009). Equity and livelihoods in Nepal's community forestry. International Journal of Social Forestry, 2(2), 101-122.

Gautam, A. P., \& Shivakoti, G. P. (2005). Conditions for successful local collective action in forestry: some evidence from the Hills of Nepal. Society \& Natural Resources, 18(2), 153-171. http://doi.org/10.1080/08941920590894534

Gautam, A. P., Shivakoti, G. P., \& Webb, E. L. (2004). A review of forest policies, institutions, and changes in the resource condition in Nepal. International Forestry Review, 6(2), 136-148. http://doi.org/10.1505/ifor.6.2.136.38397 
GoN (Government of Nepal). (2011). National population and housing census. Kathmandu.

GoN (Government of Nepal). (2014). Review of implementation of the Master Plan for the Forestry Sector: achievements and lessons. Kathmandu.

Gurung, A., Bista, R., Karki, R., Shrestha, S., Uprety, D., \& Oh, S.-E. (2012).

Community-based forest management and its role in improving forest conditions in Nepal. Small-Scale Forestry, 12(3), 377-388. http://doi.org/10.1007/s11842012-9217-z

HMGN (His Majesty's Government of Nepal). (1991). National population and housing census. Kathmandu.

HMGN (His Majesty’s Government of Nepal). (1993). Forest Act 1993. Kathmandu.

HMGN (His Majesty’s Government of Nepal). (1995). Forest Regulations 1995. Kathmandu.

HMGN (His Majesty's Government of Nepal). (2001). National population and housing census. Kathmandu.

HMGN (His Majesty’s Government of Nepal), ADB (Asian Development Bank), \& FINNIDA (Finnish International Development Agency). (1988). Master Plan for the Forestry Sector Nepal: main report. Kathmandu.

Iversen, V., Chhetry, B., Francis, P., Gurung, M., Kafle, G., Pain, A., \& Seeley, J. (2006). High value forests, hidden economies and elite capture: evidence from forest user 
groups in Nepal’s Terai. Ecological Economics, 58(1), 93-107.

http://doi.org/10.1016/j.ecolecon.2005.05.021

Jones, S. (2007). Tigers, trees and Tharu: an analysis of community forestry in the buffer zone of the Royal Chitwan National Park, Nepal. Geoforum, 38(3), 558-575. http://doi.org/10.1016/j.geoforum.2006.10.010

Karanth, K. K., \& Nepal, S. K. (2012). Local residents perception of benefits and losses from protected areas in India and Nepal. Environmental Management, 49(2), 37286. http://doi.org/10.1007/s00267-011-9778-1

KC, B., Stainback, G. A., \& Chhetri, B. B. K. (2014). Community users’ and experts’ perspective on community forestry in Nepal: a SWOT-AHP analysis. Forests, Trees and Livelihoods, 23(4), 217-231.

http://doi.org/10.1080/14728028.2014.929982

Khadka, M. (2010). Why does exclusion continue in Nepal's community forestry? Aid, knowledge and power in forest policy process. Saarbrücken: Lambert Academic Publishing.

Khadka, M., Karki, S., Karky, B. S., Kotru, R., \& Darjee, K. B. (2014). Gender equality challenges to the REDD+ initiative in Nepal. Mountain Research and Development, 34(3), 197-207. http://doi.org/10.1659/MRD-JOURNAL-D-1300081.1

Kish, L. (1965). Survey sampling. New York: J. Wiley. 
Lund, J. F., Baral, K., Bhandari, N. S., Chhetri, B. B. K., Larsen, H. O., Nielsen, Ø. J., ... Treue, T. (2014). Who benefits from taxation of forest products in Nepal's community forests? Forest Policy and Economics, 38, 119-125.

http://doi.org/10.1016/j.forpol.2013.04.010

Lyon, F. (2000). Trust, networks and norms: the creation of social capital in agricultural economies in Ghana. World Development, 28(4), 663-681. http://doi.org/10.1016/S0305-750X(99)00146-1

Mac Nally, R. (2002). Multiple regression and inference in ecology and conservation biology: further comments on identifying important predictor variables. Biodiversity and Conservation, 11(8), 1397-1401. http://doi.org/10.1023/A:1016250716679

Mahat, I. (2009). Doing fieldwork in development research: issues in applications of methodologies. In I. Mahat (Ed.), Gender and rural energy technologies in Nepal: planning and policy perspectives (p. 400). Saarbrücken, Germany: VDM Publishing.

Malla, Y. B., Neupane, H. R., \& Branney, P. J. (2003). Why aren’t poor people benefiting more from community forestry? Journal of Forest and Livelihood, 3(1), 78-92.

McDougall, C. L., Leeuwis, C., Bhattarai, T., Maharjan, M. R., \& Jiggins, J. (2013). Engaging women and the poor: adaptive collaborative governance of community forests in Nepal. Agriculture and Human Values, 30(4), 569-585. http://doi.org/10.1007/s10460-013-9434-x 
Mehta, J. N., \& Heinen, J. T. (2001). Does community-based conservation shape favorable attitudes among locals? An empirical study from Nepal. Environmental Management, 28(2), 165-177. http://doi.org/10.1007/s10531-011-9993-3

Mehta, J. N., \& Kellert, S. R. (1998). Local attitudes toward community-based conservation policy and programmes in Nepal: a case study in the Makalu-Barun Conservation Area. Environmental Conservation, 25(4), 320-333. http://doi.org/10.1017/S037689299800040X

Moser, C. A., \& Kalton, G. (1971). Survey methods in social investigation (2nd ed.). London: Heinemann Educational.

Nagendra, H. (2007). Drivers of reforestation in human-dominated forests. Proceedings of the National Academy of Sciences of the United States of America, 104(39), 15218-23. http://doi.org/10.1073/pnas.0702319104

Nagendra, H., Karmacharya, M., \& Karna, B. (2005). Evaluating forest management in Nepal: views across space and time. Ecology and Society, 10(1), 24.

Nepal, S. K., \& Spiteri, A. (2011). Linking livelihoods and conservation: an examination of local residents' perceived linkages between conservation and livelihood benefits around Nepal's Chitwan National Park. Environmental Management, 47(5), 727-738. http://doi.org/10.1007/s00267-011-9631-6

Oppenheim, A. N. (1992). Questionnaire design, interviewing, and attitude measurement. London: Pinter Publishers. 
Ostrom, E. (1990). Governing the commons: the evolution of institutions for collective action. New York: Cambridge University Press.

Ostrom, E., Schroeder, L. D., \& Wynne, S. G. (1993). Institutional incentives and sustainable development: infrastructure policies in perspective. Boulder: Westview Press.

Pandit, R., \& Bevilacqua, E. (2011a). Forest users and environmental impacts of community forestry in the hills of Nepal. Forest Policy and Economics, 13(5), 345-352. http://doi.org/10.1016/j.forpol.2011.03.009

Pandit, R., \& Bevilacqua, E. (2011b). Social heterogeneity and community forestry processes: reflections from forest users of Dhading district, Nepal. Small-Scale Forestry, 10(1), 97-113. http://doi.org/10.1007/s11842-010-9136-9

Pokharel, R. K., Tiwari, K. R., \& Rayamajhi, S. (2012). Nepal’s community forestry: need of better governance. In C. A. Okia (Ed.), Global perspectives on sustainable forest management (pp. 43-58). InTech. http://doi.org/10.5772/33439

Poudel, M., Thwaites, R., Race, D., \& Dahal, R. G. (2014). REDD+ and community forestry: implications for local communities and forest management- a case study from Nepal. International Forestry Review, 16(1), 39-54. http://doi.org/10.1505/146554814811031251

R Core Team. (2014). R: a language and environment for statistical computing. Vienna: R Foundation for Statistical Computing. Retrieved from http://www.r-project.org/ 
Sah, J. P., \& Heinen, J. T. (2002). Wetland resource use and conservation attitudes among indigenous and migrant peoples in Ghodaghodi Lake area, Nepal. Environmental Conservation, 28(04), 345-356. http://doi.org/10.1017/S0376892901000376

Sharma, P., Guha-Khasnobis, B., \& Raj Khanal, D. (2014). Nepal human development report 2014. (G. Luchsinger, Ed.). Kathmandu: GoN (Government of Nepal) \& UNDP (United Nations Development Programme).

Shivakoti, G. P., \& Ostrom, E. (2002). Improving irrigation governance and management in Nepal. Oakland: ICS Press.

Shrestha, K. K., \& McManus, P. (2007). The embeddedness of collective action in Nepalese community forestry. Small-Scale Forestry, 6(3), 273-290. http://doi.org/10.1007/s11842-007-9020-4

Spiteri, A., \& Nepal, S. K. (2008). Distributing conservation incentives in the buffer zone of Chitwan National Park, Nepal. Environmental Conservation, 35(1), 76-86. http://doi.org/10.1017/S0376892908004451

Stræde, S., \& Treue, T. (2006). Beyond buffer zone protection: a comparative study of park and buffer zone products’ importance to villagers living inside Royal Chitwan National Park and to villagers living in its buffer zone. Journal of Environmental Management, 78(3), 251-67. http://doi.org/10.1016/j.jenvman.2005.03.017 
Sudman, S., Sirken, M. G., \& Cowan, C. D. (1988). Sampling rare and elusive populations. Science (New York, N.Y.), 240(4855), 991-996. http://doi.org/10.1126/science.240.4855.991

Tashakkori, A., \& Teddlie, C. (1998). Mixed methodology: combining qualitative and quantitative approaches. Thousand Oaks: Sage Publications, Inc.

Thoms, C. A. (2008). Community control of resources and the challenge of improving local livelihoods: a critical examination of community forestry in Nepal. Geoforum, 39(3), 1452-1465. http://doi.org/10.1016/j.geoforum.2008.01.006

UNESCO (United Nations Educational Scientific and Cultural Organization). (2013). Chitwan National Park. Retrieved October 1, 2014, from http://whc.unesco.org/en/list/284 


\section{CHAPTER 3}

\section{USING AGENT-BASED MODELING TO EXAMINE VILLAGE-LEVEL LAND USE/LAND COVER CHANGE DECISION-MAKING: A FOREST CONSERVATION CASE STUDY IN BACHAULI, NEPAL}

\section{INTRODUCTION}

In recent decades, the Hindu Kush Himalayas $(\mathrm{HKH})$ region of Asia — which spans eight countries and provides essential natural resources to 210 million inhabitants within its boundaries and an additional population of 1.3 billion people downstream (Molden \& Sharma, 2013; Uddin et al., 2015)—has witnessed substantial land use/land cover change (LULCC), which can lead to changes in ecosystem services (Koschke et al., 2012; Uddin et al., 2015). To Nepal's rural poor, especially in the Terai region, forests are an important part of everyday life. Because rural communities comprise the majority of Nepal's population, they play an important role in the nation's overall social, human, and biophysical systems (Bohra \& Massey, 2009). The buffer zone (BZ) Village Development Committees (VDCs) surrounding Chitwan National Park (CNP) are at the forestry and agriculture epicenter of Nepal. Those living here primarily engage in subsistence agriculture, farming small plots of the land and earning low annual incomes. 98 percent of energy use in this area comes from biomass, largely contributing to the 25.8 million metric tons of fuel wood needed each year to meet the forest needs of Nepali people (INSE, 2005). In this region, the amount of forest resources available in ratio to the population is a growing concern. In the last 25 years, the Terai has seen both loss and 
gain in terms of forest cover, and although forest loss appears to have slowed in recent years (see Chapter 1), forests will continue to compete with pressing needs for development and agricultural expansion as rural populations grow. Community-based forest management in Nepal has been shown to be one of the most successful forest conservation programs in the developing world (Chapters 1, 2; Niraula et al., 2013), however, few studies have examined the consequences of forest conservation, as well as other initiatives, on LULCC in Nepal (Uddin et al., 2015).

The mechanisms behind deforestation are complex (Bhattarai et al., 2009; Ehrhardt-Martinez, 1998; Henderson-Sellers \& Gornitz, 1984; Fearnside, 1985; Malanson et al., 2006; Richards \& Tucker, 1988; Rolfe et al., 2000). Incorporating complexity theory has been increasingly utilized to study social ecological systems (SES) and LULLC such as deforestation (see e.g., Evans and Kelley, 2004; Lambin et al., 2003; Mena et al., 2011; Veldkamp \& Lambin, 2001; Walsh et al., 2008). Simon Levin (1998; 1999; 2003) describes ecosystems as multi-level, nonlinear, complex adaptive systems (CAS) in which evolutionary forces at lower, individual levels produce emergent patterns at higher, macroscopic levels (see e.g., Holland, 1992; 1995). This is perpetuated by anthropogenic disturbances, which can lead to outcomes such as a loss of biodiversity on a global scale (Levin, 1999). Rindfuss et al. (2008) define CAS as:

systems that exhibit (a) macro-level outcomes manifested as emergent spatial or temporal regularities, (b) decision-making with specified behaviors, (c) heterogeneity in characteristics or behavior of actors, (d) social or other interactions that affect their attributes or decisions, and (e) 
feedback mechanisms that can produce nonlinear system behaviors (p. 3; see. e.g., Axelrod \& Cohen, 1999; Holland, 1995; Waldrop, 1992).

Agent-based models (ABM) allow users to conceptualize these ideas by examining how individual agents in a system (e.g., villages in Bachauli) are influenced differently by, and adapt in response to, input variables, which aggregate to produce emergent, landscape-level outcomes.

Epstein’s 1999 paper, Agent-Based Computational Models and Generative Social Science, contributed greatly to the ways ABM is used today by presenting the tool as a robust, new-age discipline. ABM allows for more advanced exploration into the complex functionality of social systems by examining how heterogeneous and boundedly rational individuals interact and adapt in a simulated, parameterized world (see e.g., Epstein, 2006; Epstein, 2009; Epstein \& Axtell, 1996). In recent years, ABM has increasingly been used in these ways to enhance our understanding of coupled human and natural systems, complexity theory, human decision-making, cooperation, and demographic and socioeconomic influences on behavior (see e.g., An, 2012; An \& Liu, 2010; An et al., 2005; An et al., 2006; Liu et al., 2007; Matthews et al., 2007; Riolo et al., 2001; Waring et al., 2015).

Here, we create an ABM to examine what effect village attitudes toward forest conservation have on the future landscape and condition of forest cover if improved forest conservation-related policies are implemented, population growth rate fluctuates, and villages are able to mimic one another's attitudes toward forest conservation-related 
behaviors, and give an overview of some of the challenges we encountered with modeling LULCC in the place-specific context of Bachauli, Nepal (see Discussion). The model integrates remotely-sensed land cover data (Chapter 1) and a community survey of household attitudes toward forest conservation, community forestry, and forest governance institutions in Nepal (Chapter 2). By coupling qualitative survey data and quantitative land cover data to model future LULCC scenarios, we hope that

stakeholders—from NGOs, government agencies, to local communities—are better able to understand how improved forest policies, population growth, collective action, and household attitudes affect LULCC in Nepal. The recent literature supports the use of ABM to model the effects that policies might have on coupled human and natural systems (see e.g., Berger, 2005; Lempert, 2002; Zellner et al., 2008), forest management scenarios (Purnomo et al., 2005; Villino, 2014), socio-demographic variables in Nepal (Janmaat \& Lapp, 2014; Zvoleff \& An, 2014), the effects of perceptions and decision making in coupled human and natural systems (Wandersee et al., 2012), and the effects of individual cooperation and interaction on LULCC (see e.g., Bakker \& Doorn, 2009; Zvoleff \& An, 2014).

\section{METHODS}

This section is formatted according to the ODD (Overview, Design concepts, Details) Protocol, developed by Grimm et al. (2010). The full, documented model code is available in Table D.1. 


\section{Purpose}

The purpose of this model is to predict what effect villager attitudes toward forest conservation will have on the future landscape and condition of forest cover if forest conservation-related policies are implemented, population growth rate fluctuates, and villages are able to cooperate by mimicking each other's attitudes and behaviors. The percentage of the landscape that is forested is used as a metric to measure LULCC over time.

\section{Entities, State Variables, and Scales}

The agents in this model are the five villages located in Bachauli Village Development Committee (VDC)—Sauraha, Jankauli, Bachauli, Jhuwani, and Tarauli—which are each assigned to their respective location and population size. The agent set is called villages, and village is a breed and each village has a unique ID and name (ex. village 1/Bachauli). A description of all agent state variables assigned to each village is provided in Table 3.1. 
Table 3.1. Descriptions of all agent and patch variables in the model.

\begin{tabular}{|l|l|l|l|}
\hline Type & Name & Description & Bounds \\
\hline Agent & forestneed & $\begin{array}{l}\text { Attitude: Household need for forests and } \\
\text { perception of forest trends }\end{array}$ & $1-5$ \\
\cline { 2 - 4 } & cacf & $\begin{array}{l}\text { Attitude: Willingness to support collective action } \\
\text { and community forestry }\end{array}$ & $1-5$ \\
\cline { 2 - 4 } & policy & $\begin{array}{l}\text { Attitude: Supportive of current forest-related } \\
\text { institutions and policies }\end{array}$ & $1-5$ \\
\cline { 2 - 4 } & name & Name of each village to be displayed as a label & N/A \\
\cline { 2 - 4 } & population & Current population of each village & $10,905-$ \\
\cline { 2 - 4 } & pop-original & Original population of each village & $600-4,495$ \\
\cline { 2 - 4 } & village-score* & $\begin{array}{l}\text { Combined, mean score from all three input } \\
\text { attitude variables }\end{array}$ & $0-1$ \\
\cline { 2 - 4 } & support-f? & $\begin{array}{l}\text { Describes whether or not the village supports } \\
\text { forests }\end{array}$ & True, False \\
\cline { 2 - 4 } & pop-patches & $\begin{array}{l}\text { Number of patches a village is able to convert to } \\
\text { either forest or agriculture }\end{array}$ & $1-6$ \\
\hline \multirow{7}{*}{ Patch } & bachauli & LULCC GIS data assigned to patches & $1-4$ \\
\cline { 2 - 4 } & agriculture & Patch type is agriculture & True, False \\
\cline { 2 - 4 } & forest & Patch type is forest & True, False \\
\cline { 2 - 4 } & shrub & Patch type is shrub & True, False \\
\cline { 2 - 4 } & river & Patch type is river & \\
\hline
\end{tabular}

*Formula for calculating village-score: (((forestneed + cacf + policy) / 3) / 5)

Patches are categorized into four LULCC types—-forest, agriculture, shrub, and rivers

(Table 3.1). Agriculture patches also incorporate development in the study site. This is done because the two LULCC types go hand-in-hand and are virtually indistinguishable in terms of boundaries. The shrub patches are defined as areas which are not covered in river, forest, or agriculture, and represent floodplains and land covered in non-agricultural vegetation. Each patch in the model has a corresponding value ranging from 1 to 4, which is used to assign one of the four LULCC types upon Setup. In total, at Setup, there are 8,997 total forest patches, 28,116 total agriculture patches, 6,867 total shrub patches, and 797 total river patches—or, $20.1 \%$ forest, $63 \%$ agriculture, $15.2 \%$ shrub, and $1.7 \%$ river. 
A description of all patch state variables is provided in Table 3.1, and all global and local variables are explained in Table 3.2.

Table 3.2. Descriptions of all global and local variables in the model.

\begin{tabular}{|c|c|c|c|}
\hline \multirow[t]{7}{*}{ Global } & bachauli-dataset & GIS raster layer & $1-4$ \\
\hline & grow-f & Stores the number of forest patches to change & $1-14$ \\
\hline & grow-a & $\begin{array}{l}\text { Stores the number of agriculture patches to } \\
\text { change }\end{array}$ & $1-14$ \\
\hline & gov-policy & $\begin{array}{l}\text { If “True," there is a probability of increasing } \\
\text { policy by a random amount }\end{array}$ & True, False \\
\hline & equal rights-policy & $\begin{array}{l}\text { If “True,” there is a probability of increasing } \\
\text { cacf by a random amount }\end{array}$ & True, False \\
\hline & mimic-neighbors & $\begin{array}{l}\text { Slider that determines the probability of villages } \\
\text { mimicking the other four villages }\end{array}$ & $0-0.5$ \\
\hline & population-growth-rate & population growth rate per time step & $0.05-0.15$ \\
\hline \multirow[t]{10}{*}{ Local } & forest-percent & $\begin{array}{l}\text { Percentage of forest patches in the model world } \\
\text { compared to percentage at Setup }\end{array}$ & $0-176 \%$ \\
\hline & nearest-neighbors & All other villages & N/A \\
\hline & their-fn-scores & Mean forestneed of all other villages & $0-5$ \\
\hline & fn-difference & $\begin{array}{l}\text { Difference between a village's forestneed and } \\
\text { their-fn-scores }\end{array}$ & $1-14$ \\
\hline & their-cacf-scores & Mean cacf of all other villages & $0-5$ \\
\hline & cacf-difference & $\begin{array}{l}\text { Difference between a village's cacf and their- } \\
\text { cacf-scores }\end{array}$ & $0-5$ \\
\hline & their-policy-scores & Mean policy of all other villages & $0-5$ \\
\hline & policy-difference & $\begin{array}{l}\text { Difference between a village's policy and their- } \\
\text { policy-scores }\end{array}$ & $0-5$ \\
\hline & random-grow-f-patches & $\begin{array}{l}\text { Number of patches to be changed into forest } \\
\text { during the present time step }\end{array}$ & $1-14$ \\
\hline & random-grow-a-patches & $\begin{array}{l}\text { Number of patches to be changed into } \\
\text { agriculture during the present time step }\end{array}$ & $1-14$ \\
\hline
\end{tabular}




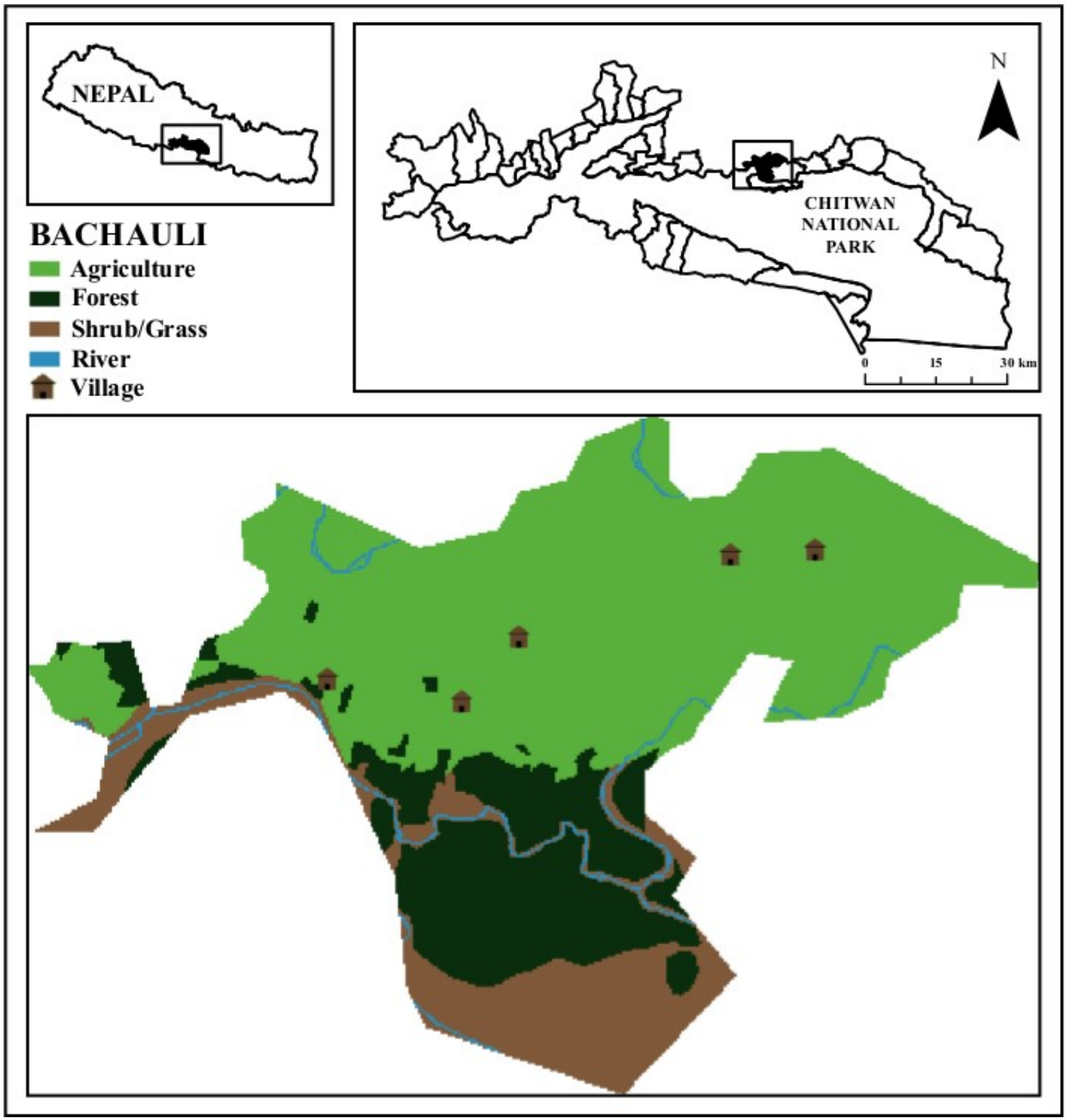

Figure 3.1. Location and NetLogo model image showing land cover of Bachauli upon Setup.

\section{Process Overview and Scheduling}

The world is comprised of $409 \times 275$ patches. However, because the shape of Bachauli VDC is not rectangular, only 44,777 of the total 112,475 patches in the world, or $\sim 40 \%$, 
are used in the model (Figure 3.1). One tick represents one month, and the model stops after 300 ticks, in 2040, when 25 years have elapsed. Below is the complete Setup procedure and the Go procedures (i.e., the processes which happen every time step/tick).

\section{Setup Model World}

- Clear world.

- Load GIS extension data and apply that data to patches in the world.

- $\quad$ Resize the world to the dimensions of the GIS layer.

- Update patch color.

- Create five villages.

- Assign population, name, label, and location to five villages.

- Set base forestneed, cacf, and policy values.

- if gov-policy is “True," there is a probability of increasing policy.

- if equal-rights-policy is “True," there is a probability of increasing cacf.

- $\quad$ Set base pop-patches.

- Reset ticks.

\section{Calculate Village Score}

- Change forestneed based on remaining-forest.

- Change forestneed based on the percentage of population growth.

- Ask each village to figure out who their 4 neighbors are. 
- Change attitude scores based on neighbors' scores.

- Recalculate village-score after changes to three variables have been made.

- If village-score is higher than 1 (on a 0-1 scale), then change it to 1.

\section{Calculate Support for Forests}

- For each village, if village-score is $>=0.582$, set support-f? = "True," otherwise, set it to "False".

\section{Calculate Patch Conversions}

- Every village adds its allotted number of patch changes (pop-patches) to the local variables grow- $a$ and grow- $f$. If the village supports forestry, it adds its patches to grow-f, and if it does not, it adds them to grow- $a$.

\section{Convert Patches}

- Locate random patches equivalent to the value of grow-a. Patches to be converted to agriculture must be either forest or shrub, and border an existing agriculture patch.

- Locate random patches equivalent to the value of grow-f. Patches to be converted to forest must be shrub, and border an existing forest patch.

- Convert located patches to forest and agriculture, accordingly.

\section{Grow Population}

- Population increases by a percentage determined by the population-growth-rate parameter slider. 


\section{Update Patch Color}

- Change newly-converted patches to the correct color based on LULCC type.

\section{Design Concepts}

\section{Basic Principles}

The ABM was constructed to replicate the actual landscape in Bachauli, which is dominated by forested, agricultural, and developed land. The model analyzes a feedback loop where villager attitudes toward forest conservation directly affect LULCC, and in return, LULCC affects villager attitudes and decision-making (Figure 3.2). Two policies are used as input variables, which examine the effects of forest policy changes on LULCC and attitudes. The two forest policies are: (1) government entities and representatives become more transparent, consistent, and considerate in their management practices and relationships with communities; and (2) equal distribution of rights, responsibilities, and revenue for the poorer, marginalized local populations. A population growth rate variable is used to examine the effects that current, increased, and decreased population growth rates have on LULCC and forest conservation. Additionally, villages have the ability to mimic behavior decisions based on their neighbors’ decisions, determined by a varying probability variable.

The model is designed to run for 25 years, ending in 2040. As the model runs, if forest cover declines, household need for forests increases, and inversely, as population increases over time, household need for agriculture (and development) increases, therefore decreasing the need for forests by villages. Attitude changes, policy reforms, population growth, and mimicking neighbors take place according to probabilities (see Stochasticity). In the model, LULCC is converted from one type to another according to 
village attitudes and other input variables. Importantly, once a forest or shrub patch has been converted to agriculture, it cannot be converted into any other LULCC type. Additionally, rivers cannot be converted to other LULCC types, forests can only be converted into agriculture, and shrub can be converted into either forest or agriculture. There are no environmental conditions, collectives, prediction, or interactions in the model.

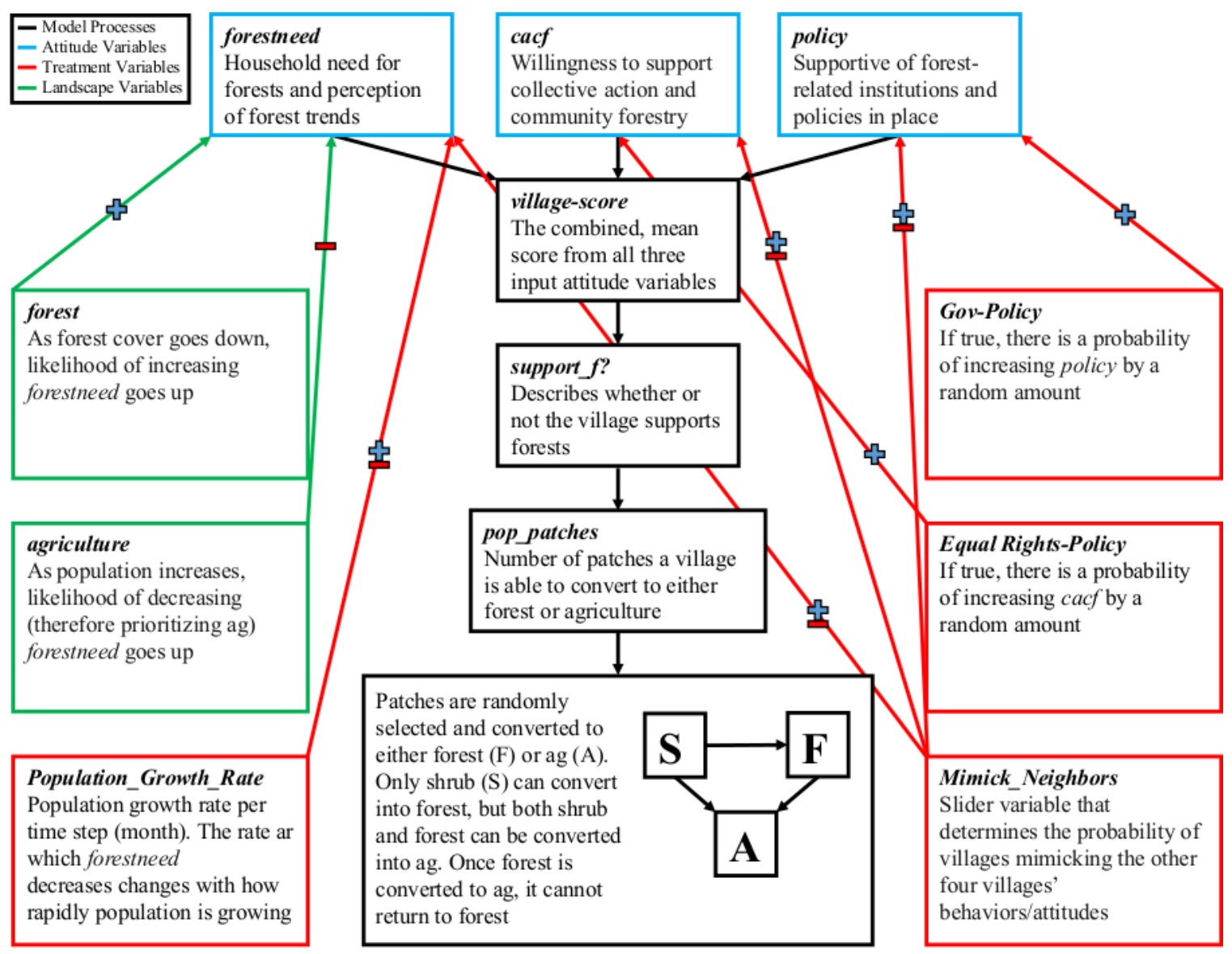

Figure 3.2. Flow chart of model variables and processes. Variables may positively and/or negatively affect other variables as indicated by plus and minus symbols. 


\section{Emergence}

Because it is unknown how or when forest, agriculture, and shrub cover will fluctuate over the next 25 years, the quantity of each LULCC type on the landscape over time is emergent. Whether or not villagers cooperate is also emergent. There is stochasticity in the ways in which villagers are able to mimic each other's attitudes, and the outcomes of this emerge as the model runs.

\section{Adaptation}

The two forms of adaptation in this model are that agents (villages) have the ability to mimic their neighbor's attitudes and support for forestry, and village attitudes adapt as land cover changes—i.e., as forest and agriculture cover fluctuates, each village’s need for forest changes in response.

\section{Objective}

Population rises, years pass, and patches are converted to either forest or agriculture. The objective is to observe LULCC over 25 years.

\section{Learning}

The only learning in this model is that villages observe the attitudes of their neighbors, and can see whether or not they support forestry or not. This allows villages to mimic/learn from other agents in the study area.

\section{Sensing}

Agents are capable of sensing the attitudes of all other villages. With this knowledge, they are able to change their attitudes to better resemble their neighbors'. 


\section{Stochasticity}

Stochasticity is used throughout this model and parameterization of variables. For each of the three attitude scores, a random-normal value is selected upon Setup, which uses the mean and standard deviation from the survey results from Chapter 2 (Table 3.3). For both policy variables_equal rights-policy and gov-policy — there is a 50\% probability upon Setup that villages will increase two of their attitude scores_policy and cacf-by a random amount between $0-5 \%$. Policy and cacf attitude scores are additionally influenced by the two policy variables each time step, based on whether or not each village supports forestry (i.e., whether their village-score $>=.582$ ). For each tick, if the village supports forestry, there is a $10 \%$ probability that their policy or cacf scores will increase by a random amount between $0-1 \%$. If the village does not support forestry, there is a $50 \%$ probability that their policy or cacf scores will increase by a random amount between 0$5 \%$.

During each time step, the percentage of forest cover on the landscape, relative to Setup, is reported (i.e., forest-percent). If random-float 100 is greater than this percentage, then villages increase their forestneed by a random amount between $0-25 \%$. Each tick, the summed population of all five villages, relative to Setup, is reported as the percentage of population growth since the model began. If random-float 100 is less than this percentage, then villages decrease their forestneed by a random amount between 025\%. The ability of agents to mimic their neighbors also incorporates stochasticity. Whether a village mimics their neighbors at all is based on a probability derived from the global parameter slider mimic-neighbors (see Submodels), and the amount a village will 
change its score to better resemble its neighbors' mean scores is chosen as a random amount within the range of the difference of scores between the village and its neighbors.

\section{Collectives}

There is no collective action beyond the fact that collectively, all villages are either regenerating or depleting the landscape of forest resources. Collectively, their attitudes and behaviors have aggregate consequences on LULCC.

\section{Observation}

For every time step, the percentage of forest, agriculture, and shrub patches within the world, relative to the amount present at Setup, is collected. Also collected are total population, the village-score of each village, the mean village-score of all five villages, the number of patches being converted each tick, and the number of villages that support forestry.

\section{$\underline{\text { Initialization }}$}

Upon initialization, five villages with a total population of roughly 11,000 are created and placed in their accurate location, based on their population and location in reality. Villages are assigned a value for each of the three attitude scores (Table 3.3). Patches are given either a true or false value for each LULCC type. The default setting for both policy parameters is False. The default setting for population-growth-rate is $0.1 \%$ based on actual national-level growth rate for the year 2013 (World Bank, 2013). Mimicneighbors is initially set to 0.25 on a $0-.5$ scale. This is done because it is the mid-range and base value for the parameter. 
Table 3.3. Base values given to variables upon initialization.

\begin{tabular}{|c|c|c|c|}
\hline Type & Variable & Base Value & Initialization Source \\
\hline \multirow[t]{5}{*}{ Agent } & forestneed & $\begin{array}{l}\text { Random-normal value selected with mean } \\
\text { of } 3.18 \text { and standard deviation of } 0.94\end{array}$ & Chapter 2 \\
\hline & cacf & $\begin{array}{l}\text { Random-normal value selected with mean } \\
\text { of } 3.35 \text { and standard deviation of } 0.81\end{array}$ & Chapter 2 \\
\hline & policy & $\begin{array}{l}\text { Random-normal value selected with mean } \\
\text { of } 2.19 \text { and standard deviation of } 1.23\end{array}$ & Chapter 2 \\
\hline & pop-original & 600-4495 (depending on village) & $\begin{array}{l}\text { S. N. Chaudhary, } \\
\text { personal communication, } \\
\text { June } 12,2014\end{array}$ \\
\hline & pop-patches & 1 - 4 (depending on village) & N/A \\
\hline \multirow[t]{4}{*}{ Patch } & agriculture & True, False & DigitalGlobe \\
\hline & forest & True, False & DigitalGlobe; Chapter 1 \\
\hline & shrub & True, False & DigitalGlobe \\
\hline & river & True, False & DigitalGlobe \\
\hline \multirow[t]{4}{*}{ Global } & gov-policy & False & N/A \\
\hline & equal rights-policy & False & N/A \\
\hline & mimic-neighbors & 0.25 & N/A \\
\hline & $\begin{array}{l}\text { population-growth- } \\
\text { rate* }\end{array}$ & $0.1 \%$ & World Bank, 2013 \\
\hline
\end{tabular}

*Formula for converting annual population growth rate (r [annual]), to monthly (r [monthly]): (r [monthly]) $=(\mathrm{r} \text { [annual] })^{1 / 12}=.012^{1 / 12}=0.001 * 100=0.1 \%$

\section{Input Data}

This model uses data sourced from Chapters 1 and 2, a Bachauli village leader (S. N.

Chaudhary, personal communication, June 12, 2014), the World Bank (2013), and

DigitalGlobe. These data are used to initialize patch land cover type, initial attitude

scores, initial population size, and the location of villages. Survey results (Chapter 2)

were categorized and summed into three overall attitude categories-(1) household need

for forests and perception of forest trends; (2) willingness to support collective action and community forestry; and (3) supportive of current forest-related institutions and policies.

The mean of these three attitudes represent each village's overall village-score, which is then used to determine each village’s support for forest conservation. Forest cover is empirically derived from the remote sensing analysis reported in Chapter 1 , and the 
agriculture, shrub, and river patches were all digitized within actual geographic boundaries using ArcMap 10.2 and a DigitalGlobe base map.

\section{Submodels}

\section{GIS Extension Data and World Setup}

As explained above, the world is comprised four LULCC types, taken directly from GIS raster values. In total, at setup, the model world is $20.1 \%$ forest, $63 \%$ agriculture, $15.2 \%$ shrub, and $1.7 \%$ river. Colors are then assigned to the different LULCC types to better convey land cover.

\section{Calculate Village-Score}

Initial village-score for each village is assigned based on survey results as explained above, and is affected by landscape and treatment variables each time step (Figure 3.2). The ability to mimic neighbor attitudes can positively or negatively affect all three attitude scores of a village. The amount of forest on the landscape remaining, relative to Setup, can positively affect forestneed. As forest cover decreases, probability of increasing forestneed increases. Population growth can negatively affect forestneed (Figure 3.2) - e.g., as population increases, probability of decreasing forestneed (prioritizing agriculture) increases. Both policy treatment variables can positively affect cacf and policy scores (see Stochasticity). During each time step, all of these factors are taken into account and all three attitude scores are then used to calculate the village-score by using the formula: (((forestneed + cacf + policy) / 3) / 5). With this, the village-score is converted to a score on a 0 to 1 scale. 


\section{Calculate Patch Changes}

First, it is decided whether or not each village supports forestry. If their village-score is greater than or equal to 0.582 , than the village supports forestry, otherwise, it does not. This value is taken from the survey results as the mean attitude score for Bachauli. It is used as the benchmark score because the results of the survey suggest that Bachauli, with a mean score of 0.582, supports forestry in general, and forests are indeed regenerating (see Chapter 2). Next, each village is allowed to change a number of patches equivalent to one patch per 1,000 people in their population (rounded). This totals to 11 patches for all five villages upon Setup, and increases as the model simulation runs and population increases. Each village “casts their land use votes” by adding to the temporary local variables grow- $a$ and grow-f. For example, if Village 0 (Sauraha) supports forestry, it will add its four patches (based on its $~ 4,000$ population upon Setup) to the local variable grow- $f$, signifying that it will convert four patches on the landscape to forest during that time step.

\section{Convert Patches}

The patches to be converted into either forest or agriculture each time step are chosen at random, so long as they border an already-existing patch of the same cover type. For example, if 10 patches are to be converted into forest (i.e., grow- $f=10$ ), then 10 random patches bordering forest will be selected. The 10 patches in this example would also have to border shrub since only shrub can be converted into forest patches.

\section{Mimic Neighbors}

Each time step, villages access the mean value for each of the three attitude scoresforestneed, cacf, and policy — of the other four villages in the model. If the mean for each 
score is different than their own, and random-float 0.5 is less than the Global variable mimic-neighbors, then that village is asked to change its attitude scores to better resemble its neighbors by adding/subtracting a random amount within the range of the difference of scores (i.e., random-float policy-difference, cacf-difference, or fn-difference). Essentially, as the global parameter mimic-neighbors value increases, the more likely villages are to mimic one another’s attitude scores.

\section{Population Growth}

Every tick, the population grows according to the population-growth-rate parameter slider, which can be set to range from 0.05 to $0.15 \%$ increase per year. With this change comes the potential for decreasing forestneed of each village by varying amounts, and increasing pop-patches of villages.

\section{Validity and Experimental Conditions}

\section{Simulation Experiments/Model Analysis}

Three experiments were conducted using nine different parameter treatments in NetLogo’s Behavior Space to verify that the parameters and model were functioning the way they were intended, and to examine the relative effects of the three input variables independently of one another to examine model sensitivity. Experiments 1, 2, and 3 examine the effects of gov-policy and equal-rights-policy, mimic-neighbors, and population-growth-rate, respectively (Table 3.4). Three treatments were used for each experiment to measure the sensitivity of LULCC with the full range of each input variable. The minimum, maximum, and base (median) values were used for mimicneighbors and population-growth-rate, and three combinations of the two policies (true or false; T/F) were examined, i.e., T/T, T/F, and F/F. 
For each experiment, the same input variable was changed for each treatment, while the other two variables remained constant at their base value (Table 3.4). The two policies were interchangeable in the context of this analysis because gov-policy positively affects the attitude variable policy, and equal-rights-policy positively affects the attitude variable cacf. These are the only two parameters that affect these two attitudes, so they essentially have the same positive effect on each agent's overall village-score and LULCC decision. Therefore, Treatment 2 could be hypothetically changed to make govpolicy false, and equal-rights-policy true, and the outcomes of the experiment would be arguably the same. For each treatment, 50 trials were run for 300 time steps (25 years) in NetLogo’s Behavior Space. The data were then formatted in Microsoft Excel and analyzed using the "Stats Package” in version 3.1.2 of the R Statistical Computing Software (R Core Team, 2014).

Table 3.4. Treatment conditions for each experiment.

\begin{tabular}{|l|l|l|l|l|l|}
\hline Experiment & Treatment & gov-policy & $\begin{array}{l}\text { equal-rights- } \\
\text { policy }\end{array}$ & $\begin{array}{l}\text { mimic- } \\
\text { neighbors }\end{array}$ & $\begin{array}{l}\text { population- } \\
\text { growth-rate }\end{array}$ \\
\hline 1 & 1 & $\mathrm{~F}$ & $\mathrm{~F}$ & 0.25 & 0.1 \\
1 & 2 & $\mathrm{~T}$ & $\mathrm{~F}$ & 0.25 & 0.1 \\
1 & 3 & $\mathrm{~T}$ & $\mathrm{~T}$ & 0.25 & 0.1 \\
\hline 2 & 4 & $\mathrm{~F}$ & $\mathrm{~F}$ & 0.0 & 0.1 \\
2 & 5 & $\mathrm{~F}$ & $\mathrm{~F}$ & 0.25 & 0.1 \\
2 & 6 & $\mathrm{~F}$ & $\mathrm{~F}$ & 0.5 & 0.1 \\
\hline 3 & 7 & $\mathrm{~F}$ & $\mathrm{~F}$ & 0.25 & 0.05 \\
3 & 8 & $\mathrm{~F}$ & $\mathrm{~F}$ & 0.25 & 0.1 \\
3 & 9 & $\mathrm{~F}$ & $\mathrm{~F}$ & 0.25 & 0.15 \\
\hline
\end{tabular}

\section{Experiment 1}

Without varying levels of policy reform, how does forest cover and LULCC fluctuate over 25 years? This experiment using three treatments tests what would happen if neither, 
just one, or both policies were implemented, when mimic-neighbors and populationgrowth-rate stay constant at their base values. We hypothesized that without either policy in-place, there will be a fine balance between conversion to forest and conversion to agriculture, but ultimately, forest cover will likely decline due to population growth and increased pressure on forests. With one policy in-place, we hypothesize that forest cover will increase slightly over time, and with both in place, forest cover will increase dramatically.

\section{Experiment 2}

With varying ability to mimic each other's attitudes and LULCC decisions, how does forest cover and LULCC fluctuate over 25 years? This experiment uses three treatments to test what would happen if villages were less likely, likely, and more likely to mimic one another's attitudes regarding forest conservation, while gov-policy, equal-rightspolicy and population-growth-rate stay constant at their base values. We hypothesized that forest cover will not change dramatically between values for mimic-neighbors. It will only affect LULCC by unifying the five villages' decision to either prioritize forests or not. It will not increase the likelihood of slowing forest loss or regenerating forest cover.

\section{Experiment 3}

With varying rates of population growth, how does forest cover and LULCC fluctuate over 25 years? This experiment uses three treatments to test what would happen if population stayed at its current rate, was decreased by $50 \%$, and increased by $50 \%$, while gov-policy, equal-rights-policy and mimic-neighbors stay constant at their base values. We hypothesized that the lower the population growth rate, the more forest cover will be 
present after 25 years. The amount of forest cover will be significantly different between the two treatments which decreased and increased the growth rate by $50 \%$.

\section{RESULTS}

\section{Experiment 1}

For 50 model runs, the mean percent forest cover for the year 2040 for Treatments 1, 2, and 3 was found to be $14.66 \%, 22.29 \%$, and $27.44 \%$, respectively (Figure 3.3). Using two-sample $t$ tests with a $95 \%$ confidence interval $(\alpha=0.05)$, a significant difference was found between the resulting forest cover percentages in 2040 between Treatments 1 and 2, Treatments 1 and 3, and Treatments 2 and 3 ( $p<0.001$ ) (Figure 3.4).

\section{Experiment 2}

For 50 model runs, the mean percent forest cover for the year 2040 for Treatments 4, 5, and 6 was found to be $14.61 \%, 14.67 \%$, and $14.83 \%$, respectively (Figure 3.3). Using two-sample $\mathrm{t}$ tests with a $95 \%$ confidence interval $(\alpha=0.05)$, no significant difference was found between the resulting forest cover percentages in 2040 between Treatments 4 and $5(p<0.77)$, Treatments 4 and $6(p<0.25)$, and Treatments 5 and $6(p<0.37)$ (Figure 3.4).

\section{Experiment 3}

For 50 model runs, the mean percent forest cover for the year 2040 for Treatments 7, 8, and 9 was found to be $15.41 \%, 14.46 \%$, and $14.13 \%$, respectively (Figure 3.3). Using two-sample $t$ tests with a $95 \%$ confidence interval $(\alpha=0.05)$, a significant difference was 
found between the resulting forest cover percentages in 2040 between Treatments 7 and 8 $(p=0.001)$, Treatments 7 and $9(p<0.001)$, and Treatments 8 and $9(p=0.03)$ (Figure 3.4).

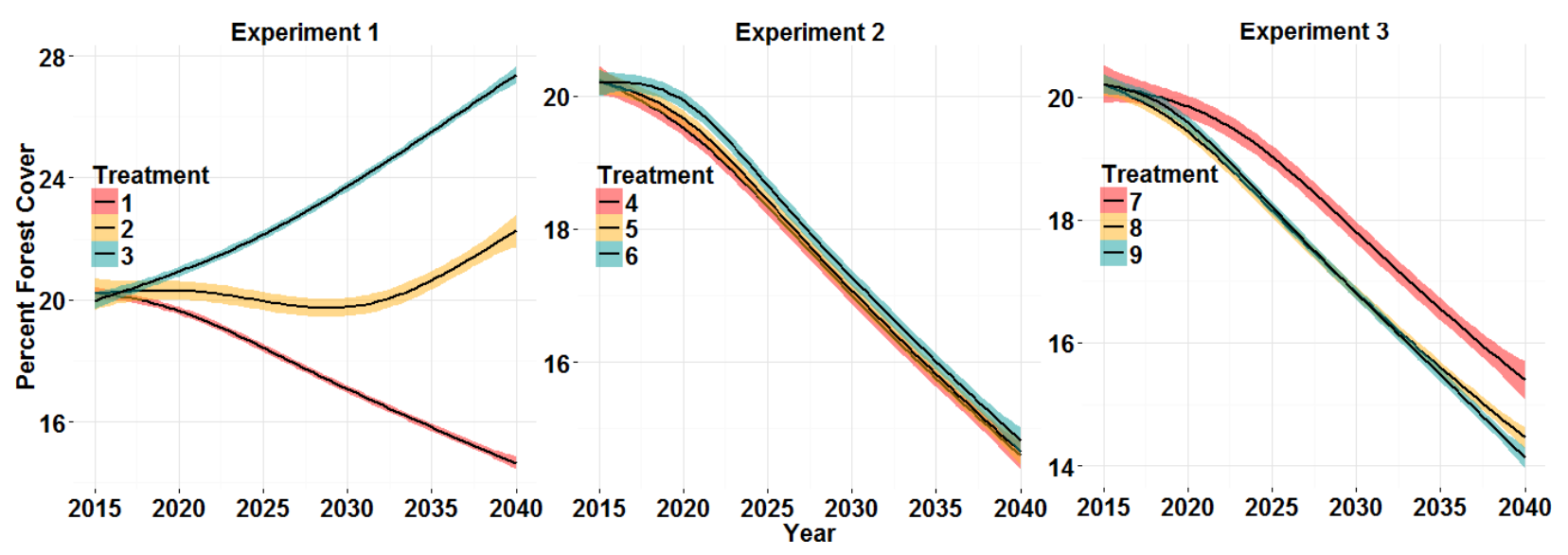

Figure 3.3. Mean percent forest cover and standard error between 2015 and 2040 for all nine treatments, for all 50 model runs. 


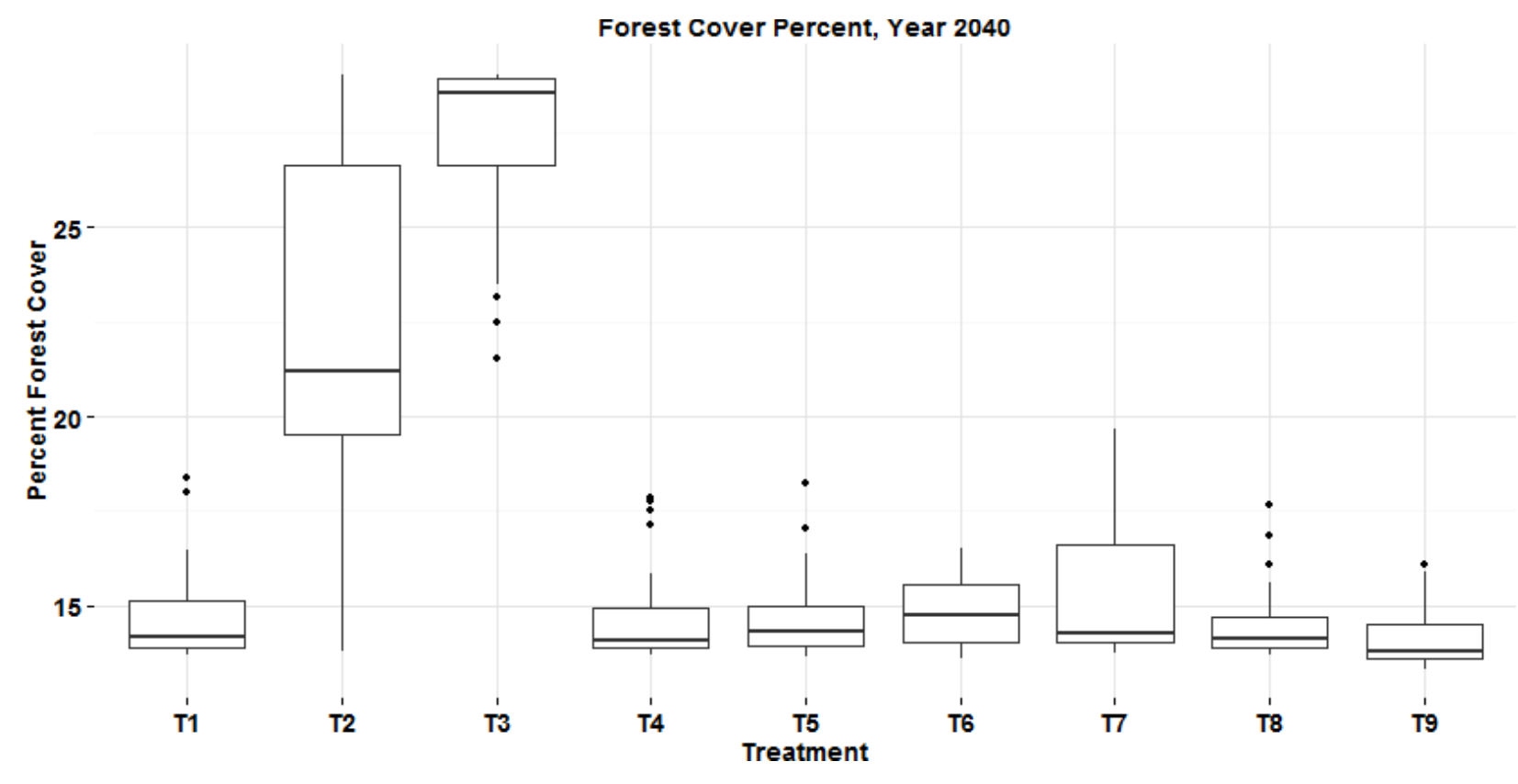

Figure 3.4. Boxplots for percent forest cover for the year 2040 for all nine treatments $(T=$ treatment), for all 50 model runs of each treatment.

\section{DISCUSSION}

The objective of this model was to explore what effect village attitudes toward forest conservation would have on the future landscape and extent of forest cover if improved policies-i.e., (1) government entities and representatives become more transparent, consistent, and considerate in their management practices and relationships with communities; and (2) equal distribution of rights, responsibilities, and revenue for the poorer, marginalized local populations - are implemented, population growth rate fluctuates, and villages are able to cooperate by mimicking each other's attitudes and behaviors. The percentage of the landscape that is forested was used as a metric to measure LULCC over time. Results from the three model experiments provide useful 
data for forest sector representatives, policy-makers, and other forest resource stakeholders in Nepal.

Experiment 1 examined the effects of improving forest-related policies to examine how forest cover might fluctuate in the next 25 years with one or two key policies implemented (see Chapter 2, Discussion, for explanation of policies used). The results of this experiment suggest that implementing new policies, aimed at improving individual attitudes toward forest conservation-oriented behaviors, would have a dramatic effect on the forest cover in Bachauli over time.

The results from Experiments 2 and 3 were less profound than Experiment 1, although useful conclusions can be drawn nonetheless. Results show that the ability for villages to cooperate and mimic their neighbors, regardless of varying probabilities of occurrence, has little effect on forest cover after 25 years. This emergent result exemplifies the usefulness of ABM; incorporating agent interaction allows for results that a user might not have been able to determine with a standard computational or statistical model.

Experiment 3 examined the effects that different population growth rates will have on forest cover over time. Three rates of monthly growth were used in the experiment-the current growth rate of $0.1 \%, 0.05 \%$, and $0.15 \%$. A significant difference, although marginal, was found in the percentage of forest cover after 25 years between all three treatment values, suggesting that the rate at which population is growing in this SES has a significant effect on forest conservation. 
Fundamentally, recent ABM literature supports the submodels used in this model, i.e., policy analysis (e.g., Florent \& Enrico, 2015; Salle, 2015; Sauvageau \& Frayret, 2015; Villino, 2014), population dynamics (e.g., Graciani Rodrigues et al., 2015; Mudimu \& Engelbrecht, 2015; Wurzer et al., 2015), and agent cooperation (i.e., mimicneighbors; e.g., Bausch, 2014; Bristow et al., 2014; Campennì \& Schino, 2014; Wunder et al., 2013; Zhang et al., 2015). Although the data used for this model were empiricallyderived, modeling human behavior is a complex and challenging task (Couclelis, 2001; Langevin et al., 2015; Parker et al., 2002; Smajgl \& Barreteau, 2013; Turkay et al., 2011). ABMs are intended to be simplified representations of a real-world system, with boundedly rational agents (Epstein, 1999; Railsback \& Grimm, 2012). However, the complexity of modeling LULCC in an SES elicits two questions: (1) are all relevant variables incorporated and empirically parameterized in a way that accurately resembles the real-world system in which the model resides? And (2) are the results and uncertainties explained by the scale at which the landscape and parameters are modeled?

Diedrich et al. (2003) describe four generalized approaches for understanding models of landscape change and form at different scales, which they introduce to help explain the varying levels of "realism" in a landscape model and are not intended to be adopted as modeling terminology per se. Figure 3.5 describes these four approachesdetailed realism, apparent realism, statistical realism, and essential realism—using paintings as metaphors for each. We introduce this idea of "realism" here to put the following discussion into context, suggesting that some challenges with modeling LULCC and behavior decisions are a product of scale and complexity, and are therefore inherent. 
$\mathrm{ABM}$ is a discipline centered on using empirical and theoretical understandings of a system to model hypotheses about system processes and interactions. Detailed realism in landscape models would require an extremely fine-scale degree of knowledge about the interactions and stochasticity of a system, and is theoretically unrealistic to achieve. Statistical realism suggests that, while the landscape in the model is not necessarily recognizable, the information that we know about that system—i.e., the rules—is organized in a way that suggests organization representative of the real-world (Diedrich et al., 2003).

Essential realism is seen in a model that incorporates only broad, large-scale mechanisms and patterns of a system, which can be useful in enhancing general understanding, but is less valuable when trying to examine system intricacies or draw specific conclusions. Apparent realism is perhaps the most typical modeling approach used, and as the painting in Figure 3.5 suggests, it represents a detailed model, which resembles a real-world system to some degree, but at a coarser scale, and typically incorporates rules and parameters that are used to examine hypotheses about natural and human system processes.

Because of computational demands, current lack of knowledge about how to scale up finer scale mechanisms, and a lack of quantitative morphology or dynamics data, those models that examine large-scale landscapes are by necessity approximate and create what can be called an apparent realism. Insight may nonetheless be gained (Diedrich et al., 2003, p. 7). 

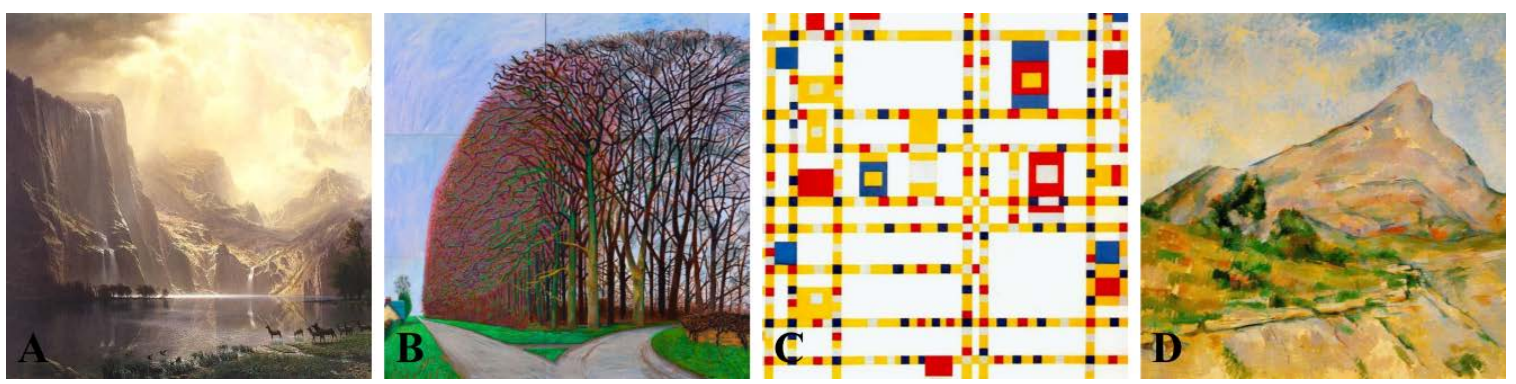

Figure 3.5. Art as metaphors for the varied modeling approaches: (A) Detailed Realism;

(B) Apparent Realism; (C) Statistical Realism; (D) Essential Realism (modified from

Dietrich et al., 2003). ${ }^{2}$

The following discussion outlines the key challenges that were experienced while using ABM to model SES in the place-specific context of Bachauli, Nepal. As Miller (2015) eloquently states:

All methods have shortcomings. To temper earlier comments about the potential of agent-based modeling to contribute to theory building and testing in management and organization studies, some important limitations of the method-from a critical realist perspective- should be made explicit (p, 188).

\footnotetext{
${ }^{2}$ (A) A. Bierstadt, 1868, Among the Sierra Nevada, California (Smithsonian American Art Museum, DC). (B) D. Hockney, 2008, Bigger Trees Near Warter (@ David Hockney). (C) P. Mondrian, 1943, Broadway Boogie Woogie (Museum of Modern Art, NY). (D) P. Cézanne, 1897-98, Le Mont Sainte-Victoire (The Hermitage, St. Petersburg, Russia).
} 


\section{Data Availability and Parameter Inclusion in Developing Nations Such as Nepal}

When designing an ABM, the user must make choices about which parameters to incorporate, and which ones to exclude. These decisions are essential to the validity and overall success of a model (Azuaje, 2011; Chavali et al., 2008; Grimm \& Railsback, 2006; Kaul \& Ventikos, 2013; Kaul \& Ventikos, 2015; Thorne et al., 2007a; Thorne et al., 2007b). Chosen parameters should be derived from empirical data, and their inclusion should be essential to the overall functionality of the model (Kaul \& Ventikos, 2015). Thorne et al. (2007a; 2007b) suggest that the ability to incorporate all relevant data might not always be possible due to a "lack of relevant published data, unpublished experiments and absence of more advanced protocols/ apparatuses/ techniques needed to conduct a particular experiment” (Kaul \& Ventikos, 2015, p. 144). We parameterized our model using data empirically-collected through remote sensing and in-country household surveys. Despite this, there are parameters which were either not included or could be improved upon if more reliable data were available.

Developing countries_-including those in the Hindu Kush Himalayas (HKH) region (Bajracharya et al., 2010, Uddin et al., 2015)—are commonly faced with complex LULCC challenges and quite often lack empirical, reliable sources of information and data needed to evaluate alternative policies (Saqalli et al., 2010). The Intergovernmental Panel on Climate Change (IPCC, 2007a, 2007b) stated that the HKH region was a "datadeficit area” (Singh et al., 2011; Uddin et al., 2015), and other studies suggest that Nepal lacks sufficient socio-economic and forestry-related data (DFRS/FRA, 2014; Kandel, 2010), data regarding dead-wood (fuel-wood) use (Christensen et al., 2009), data about the social inclusiveness of Community Forest User Groups (CFUGs) in terms of 
marginalized classes and revenue distribution (Khadka et al., 2014), and national forest cover data (DFRS/FRA, 2014; FAO, 2009).

Although institutions and researchers are continually acquiring new data (Singh et al., 2011), the HKH region is still considered data deficient eight years after the 2007 IPCC report was released (Gilani et al., 2015). Nepal’s Department of Forest Research and Survey released a "Data Needs Assessment” in April of 2014 which detailed the need for data pertaining to the forestry sector (DFRS/FRA, 2014). The executive summary of the report states that:

The extant forestry information cannot meet the need of the forestry sector of Nepal for reliable, accurate and up-to-date forestry information for use in strategic planning, policy and management decisions; for three key reasons: data is scattered across different organisations, there is neither policy nor action on periodic updating, and institutional capacity for data management is inadequate. The last national forest inventory (NFI) was carried out in the early 1990s and national-level data has not been updated since. In many case, the data collected do not comply with the national and international reporting requirements (DFRS/FRA, 2014, p. iv).

This statement refers to forest-related data at the national level, which accentuates the concern for data availability at smaller scales — which is needed for modeling LULCC at the individual or village level. The report furthers this sentiment by stating that "the data 
demand of community-based forestry user groups (CFUGs) for use in management planning was beyond [our] scope” (DFRS/FRA, 2014, p. iv).

\section{Challenges with Using Social Surveys in ABM}

With LULCC ABMs, i.e., modeling both human and natural systems, there are a multitude of variables which play important roles in the way that humans interact with, and change, the natural landscape. Additionally, the ways in which landscape-level ecological systems—such as forests—-function are invariably complex. When the interactions between human and natural systems are incorporated into one model, the task is especially complex (Berkes et al., 1998; Berkes et al., 2003; Couclelis, 2001;

Norgaard, 1994). Using survey data in ABM, such as we have done here, requires making the assumption that upscaling survey results from the sample that was collected will be representative of the population of the model study site, albeit simplified. This can be a challenging assumption to make when certain behaviors, relevant to the study, are not particularly common in the real world system. Two problems potentially arise from this: (1) if less-common behaviors are represented in the survey results and upscaled, then they could be overrepresented in the survey results and ABM parameterization; and (2) if the behavior is not represented in the survey results, then it will not be incorporated into the ABM, therefore excluding a relevant and potentially important component of the system (Smajgl \& Barreteau, 2013).

When modelers make simplifying assumptions, they position their work along a continuum from concrete to isolated. A model is concrete to the extent that it reflects details in the social process and isolated to the extent 
that it reduces such details in order to focus on particular causal mechanisms (Miller, 2015, p. 179; Windrum et al., 2007).

\section{Modeling Policy Change}

For a myriad of reasons, predicting how local attitudes toward LULCC decisions will change if improved resource-related policies are implemented is difficult. In the context of forest resource conservation in rural Nepal, local people commonly believe strongly in decentralized management authority of forests in their communities. Rural communities have been using traditional methods for managing natural resources such as forests for long periods of time (Nagendra \& Ostrom, 2007), and when considering policy changes, these experiences should be taken into careful consideration by policy-makers (Shivakoti \& Ostrom, 2008).

Regardless of whether a new policy is aimed at improving relationships between local people and forest-sector representatives, or reducing the marginalization of underrepresented social classes — which would likely be viewed as positive changes— some might view any level of governing policy or institution as undermining to their traditional management methods. Additionally, some Bachauli villagers, as well as residents in other areas of the buffer zone of Chitwan National Park, are unlikely to support any type of centralized forest management policy because they feel that they have been alienated from once-available resources due to land protection (Agrawal \& Ostrom, 2006). Changing the perceptions and attitudes of these individuals poses challenges. However, in order for government conservation efforts to be effective, local 
people must support the problems being addressed, as well as formal policies in-place (Agrawal \& Ostrom, 2006; Hayes \& Ostrom 2005).

SES have been classified as: (1) nonlinear, which produces uncertainty (Berkes et al., 2003);(2) self-organized, which produces emergence (Garmestani, 2014; Levin et al., 2013); and (3) complex adapting systems (Berkes et al., 1998; Holland, 1992; Holland, 1995; Levin et al., 2013), which makes modeling policy effectiveness difficult (Levin et al., 2013). In SES, landscape outcomes are an aggregate effect of small-scale, local actions, which then feed back and affect individual behaviors and actions, usually over varyingly longer time scales (Levin et al., 2013). For this reason, "the possibilities of non-marginal changes, unobserved slow structural changes, spatial variation and strategic behavior are all examples of management and policy challenges related to the complex adaptive system properties of social-ecological systems” (Levin et al., 2013, p. 113).

Our findings here—-that policy reform would dramatically improve forest cover over the next 25 years—should be viewed in light of these challenges. Anderies (2015) states that:
Although simple deterministic models with mild nonlinearities generate important insights, they are insufficient for designing solutions. Real- world systems not only exhibit nonlinear dynamics but also exhibit complexity of a different sort: the sheer number of interacting elements that comprise them. This type of complexity brings with it deep uncertainty that makes policymaking very difficult in practice (p. 260). 


\section{$\underline{\text { Heterogeneity at Different Scales }}$}

All villages were given the same base attitude scores, when in reality, they are likely different from one another due to heterogeneity among individuals in each village and their respective distance from Chitwan National Park and available resources, among other social and natural factors. A recent study conducted by Pérez \& Janssen (2015) suggests that spatial heterogeneity and landscape configuration play important roles in the level of cooperation and collective action between agents when modeling resource use. The results of their model suggest that the more heterogeneous the landscape is, the more cooperation emerges from agents. These findings, however, consider the location of resources and the movement capabilities of individuals in the model. In our model, while there is landscape heterogeneity, it is not effectively used as a variable in the decisionmaking abilities of agents (i.e., villages) because agents at the individual level were not incorporated.

Replacing villages with their respective populations would entail parameterizing heterogeneity in terms of variables such as movement capabilities, individual attitudes, and distance to resources, which would increase the model's complexity immensely. Increasing model complexity creates user and computational costs because it: (1) increases computational requirements; (2) reduces the ability to conduct sensitivity analyses; and (3) makes interpreting model behavior and linking it to the model's structure more challenging (Rahmandad \& Sterman, 2008).

Regardless, our research question was designed to measure the aggregate effects of individuals (i.e., villages), not individuals themselves, to examine how villages interact with one another on the landscape level. Intuitively, the solution to the loss of individual- 
level heterogeneity would be to reduce the scale of the model to the individual level. However, the model is already small in scale compared to modeling LULCC for the entire buffer zone of CNP, or ideally, in the future, at a national level. Modeling LULCC and attitudes and behavior at larger scales would mean incorporating hundreds of thousands, or even millions, of heterogeneous agents.

For these reasons, ABM in this context is seemingly well-suited for either more complex, small-scale, or generalized, larger-scale scenarios. This makes it challenging to incorporate both heterogeneity at the individual level in Bachauli, as well as at the village level, which is an aggregate product of the heterogeneous populations of each village. However, if the model were to remain as it is, individual-level heterogeneity would remain ignored, resulting in a model that is arguably unrepresentative of the real-world system. After all, the observed behavior in a model is a product of behavior and interactions at the individual (i.e., village) level (Matthews et al., 2007). Varughese \& Ostrom (2001, citing Blair, 1996) found that excluding individual-level heterogeneity in the context of our study site could invalidate findings because:

The sociocultural composition of a settlement or group of settlements may result in a difference of interests among forest users that influences the organization of forest governance and management. Differences in social class and ethnicity can make consensus-building and norm-enforcement difficult (p. 749). 
The effect of cooperation (i.e., mimic-neighbors), and individual and aggregate attitudes and behaviors in our model would likely change if the scale at which heterogeneity was incorporated were to change, which poses validation concerns.

\section{$\underline{\text { Population Dynamics }}$}

Resource depletion is commonly attributed in part to population growth (Poteete \& Ostrom, 2004). Despite this, population growth and/or an associated increase in market pressure for resources such as forests is not universally correlated to their depletion (Agrawal, 1995). On the contrary, some studies suggest that an increase in population can lead to technological advancements, which can mitigate resources loss (Boserup, 1965; Poteete \& Ostrom, 2004). The consequences of population growth are complicated, and many studies conducted in Nepal and elsewhere argue that there is no connection between population growth and forest resource depletion at the community level (Poteete \& Ostrom, 2004; see e.g., Agrawal, 1995; Fairhead \& Leach, 1996; Fox, 1993; Varughese, 2000).

In our model, population growth is parameterized to negatively affect village attitudes towards forest conservation with the rationale that an increase in population will: (1) increase the need for forest products and pressure on forests; and (2) increase the prioritization of agriculture and development over forests in order to meet the nutritional needs of more people. While likely realistic, these assumptions are based on observed patterns, not empirical data. In fact, while not necessarily correlated, the opposite pattern can be seen in Bachauli, whereas forest cover has increased alongside population growth in the last eight years (see Chapter 1). Even with empirical data of population dynamics and forest resource trends, assuming that the two variables are either positively or 
negatively correlated in our study site—when using ABM to model future LULCC— would likely imply supposition.

\section{Climate Change}

Nepal is one of the world's most at-risk countries in regard to climate change (Ojha et al., 2015). Agricultural production in Nepal, and overall food security on a global scale, is highly susceptible to climate change (Bhatt et al., 2014; Malla, 2008; Olesen \& Bindi, 2002; Palazzoli et al., 2015; Parry et al., 2004), and ecological factors, landscape diversity, and social instability in Nepal make the country particularly at-risk (see e.g., Aryal, 2011; Bharati et al., 2014; Chhetri \& Nyaupanea, 2009; Eriksson et al., 2009; Karki \& Gurung, 2012; NCVST, 2009; Maskey et al., 2011; Palazzoli et al., 2015; Rai, 2007). Uddin et al. (2015) states that:

Climate change impacts, habitat fragmentation, and high population density are changing the way people in Nepal (and the HKH) are using land and causing land use conflicts. These multiple drivers of change and the interactions between them need to be understood so that policy makers and planners can better manage Nepal's natural resources (p. 82).

It is not possible to predict the outcomes of climate change with certainty (Collins et al., 2006). Projections assume some amount of uncertainty due to unknown future levels of greenhouse gasses, naturally-occurring climate variables, imperfections in model design and construction (Collins et al., 2006), the use of downscaling methods, and the internal 
variability of climate systems (Agarwal et al., 2014; Hawkins \& Sutton, 2011; Hu et al., 2013), the use of simplified and/or fixed models (Darbyshire et al., 2014), and because of uncertainty regarding nonlinear species behavior in response to change (Nelson et al., 2014).

The impacts of climate change on LULCC in Bachauli are not incorporated into this model because, although some studies have been conducted (see e.g., Thapa et al., 2013), there is not sufficient data about the consequences of climate change on forest conservation and agricultural expansion in Bachauli. If projections were available, there would still be significant uncertainty in using them as parameters due to social factors. The Nepal Climate Change Support Programme (NCCSP) currently has Local Adaptation Plans of Action (LAPAs), monitoring, and evaluation systems in only 14 of 75 districts in Nepal—all of which are located in the far-west and mid-west zones of the country (UNDP, 2014). As of spring, 2015, there are no government climate change programs in the central Terai region, which is where Bachauli is located, and where almost half of all Nepalese live. While uncertainty to some degree is unavoidable regarding both climate change modeling and ABM, climate change impact projections are especially uncertain at smaller, local scales (Devkota, 2014; Marin, 2010), which poses challenges for incorporating this as a parameter in our model.

\section{CONCLUSION}

From the literature, it is clear that ABM is a pragmatic and effective tool with innumerable scientific applications. It fills a much-needed niche in SES science for 
modeling complexity theory, individual interaction, and heterogeneity in ways that traditional computational and statistical models cannot. Additionally, it allows the user to model theoretical, hypothetical, and complex systems in a way that is visually discernable to stakeholders.

The results of this model suggest that implementing new policies, aimed at improving individual attitudes toward forest conservation-oriented behaviors, would have a dramatic effect on the forest cover in Bachauli over time. The ability for villages to cooperate and mimic their neighbors, regardless of varying probabilities of occurrence, will likely have little effect on forest cover after 25 years. Additionally, the rate at which population is growing in this SES has a significant effect on forest conservation. Despite clear strengths, there are challenges with modeling forest conservation dynamics and LULCC in Bachuli at different scales. Importantly, when policy, development, or conservation-related recommendations are drawn from ABM findings, "norms of transparency should encourage sharing programs with other researchers for verification purposes. Independent replication is another important practice to detect and correct errors and check the robustness of findings” (Axelrod, 1997; Axtell et al., 1996; Miller, 2015; Wilensky \& Rand, 2007).

\section{ACKNOWLEDGMENTS}

Thanks to Timothy Waring for his ABM expertise and mentoring, and Jessica Leahy and Emily Silver for their invaluable contributions and assistance. This research was supported by National Science Foundation award EPS-0904155 to Maine EPSCoR 
Sustainability Solutions Initiative at the University of Maine, McIntire-Stennis grant number MEO-M-700510-13, and the USDA National Institute of Food and Agriculture. Additional support was provided by the Maine Agriculture and Forestry Experimental Station (Publication \# 3405) and the Center for Research on Sustainable Forests.

\section{LITERATURE CITED}

Agarwal, A., Babel, M. S., \& Maskey, S. (2014). Analysis of future precipitation in the Koshi River Basin, Nepal. Journal of Hydrology, 513, 422-434. http://doi.org/10.1016/j.jhydrol.2014.03.047

Agrawal, A. (1995). Population pressure = forest degradation: an oversimplistic equation? Unasylva, 181(46), 50-58.

Agrawal, A., \& Ostrom, E. (2006). Political science and conservation biology: A dialog of the deaf. Conservation Biology, 20(3), 681-682. http://doi.org/10.1111/j.15231739.2006.00468.x

An, L. (2012). Modeling human decisions in coupled human and natural systems: Review of agent-based models. Ecological Modelling, 229, 25-36. http://doi.org/10.1016/j.ecolmodel.2011.07.010

An, L., He, G., Liang, Z., \& Liu, J. (2006). Impacts of demographic and socioeconomic factors on spatio-temporal dynamics of panda habitat. Biodiversity and Conservation, 15(8), 2343-2363. http://doi.org/10.1007/s10531-004-1064-6 
An, L., Linderman, M., Qi, J., \& Shortridge, A. (2005). Exploring complexity in a human-environment system: an agent-based spatial model for multidisciplinary and multiscale integration. The Annals of the Association of American Geographers, 95(1), 54-79. http://doi.org/10.1111/j.1467-8306.2005.00450.x

An, L., \& Liu, J. (2010). Long-term effects of family planning and other determinants of fertility on population and environment: agent-based modeling evidence from Wolong Nature Reserve, China. Population and Environment, 31(6), 427-459. http://doi.org/10.1007/s11111-010-0111-3

Anderies, J. M. (2015). Understanding the dynamics of sustainable social-ecological systems: human behavior, institutions, and regulatory feedback networks. Bulletin of Mathematical Biology, 77(2), 259 - 80. http://doi.org/10.1007/s11538-0140030-z

Aryal, B. P., Regmi, H., Sah, S. N., Acharya, K., Rimal, U. H., \& Pahari, K. (2011). Crop situation update (a joint assessment of 2010 summer crops and outlook for 2011 winter crops). Retrieved from http://documents.wfp.org/stellent/groups/public/documents/ena/wfp234049.pdf

Axelrod, R. M. (1997). Advancing the art of simulation in the social sciences.

Complexity, 3(2), 16 - 22. http://doi.org/10.1002/(SICI)10990526(199711/12)3:2<16::AID-CPLX4>3.0.CO;2-K

Axelrod, R. M., \& Cohen, M. D. (1999). Harnessing complexity: organizational implications of a scientific frontier. New York: Free Press. 
Axtell, R., Axelrod, R. M., Epstein, J. M., \& Cohen, M. D. (1996). Aligning simulation models: a case study and results. Computational \& Mathematical Organization Theory, 1(2), 123-141. http://doi.org/10.1007/BF01299065

Azuajeu, F. (2011). Computational discrete models of tissue growth and regeneration. Briefings in Bioinformatics, 12(1), 64-77.

Bajracharya, B., Uddin, K., Chettri, N., Shrestha, B., \& Siddiqui, S. A. (2010). Understanding land cover change using a harmonized classification system in the Himalaya. Mountain Research and Development, 30(2), 143-156.

Bakker, M. M., \& van Doorn, A. M. (2009). Farmer-specific relationships between land use change and landscape factors: Introducing agents in empirical land use modelling. Land Use Policy, 26(3), 809-817.

Bausch, A. W. (2014). Evolving intergroup cooperation. Computational \& Mathematical Organization Theory, 20(4), 369 - 393. http://doi.org/10.1007/s10588-013-91701

Berger, T. (2001). Agent-based spatial models applied to agriculture: a simulation tool for technology diffusion, resource use changes and policy analysis. In Agricultural Economics (Vol. 25, pp. 245-260).

Berkes, F., Colding, J., \& Folke, C. (2003). Navigating social-ecological systems: building resilience for complexity and change. New York, Cambridge, U.K: Cambridge University Press. 
Berkes, F., Folke, C., \& Colding, J. (1998). Linking social and ecological systems: management practices and social mechanisms for building resilience. New York, Cambridge, UK: Cambridge University Press.

Bharati, L., Gurung, P., Jayakody, P., Smakhtin, V., \& Bhattarai, U. (2014). The projected impact of climate change on water availability and development in the Koshi Basin, Nepal. Mountain Research and Development, 34(2), 118-130. Retrieved from http://dx.doi.org/10.1659/MRD-JOURNAL-D-13-00096.1

Bhatt, D., Maskey, S., Babel, M. S., Uhlenbrook, S., \& Prasad, K. C. (2014). Climate trends and impacts on crop production in the Koshi River basin of Nepal. Regional Environmental Change, 14(4), 1291-1301.

Bhattarai, K., Conway, D., \& Yousef, M. (2009). Determinants of deforestation in Nepal's Central Development Region. Journal of Environmental Management, 91(2), 471-488.

Bohra, P., \& Massey, D. S. (2009). Processes of internal and international migration from Chitwan, Nepal. International Migration Review, 43(3), 621-651.

Boserup, E. (1965). The conditions of agricultural growth : the economics of agrarian change under population pressure. Population Studies, 20(1), 1-108. http://doi.org/10.2307/2172620

Bristow, M., Fang, L., \& Hipel, K. W. (2014). Agent-based modeling of competitive and cooperative behavior under conflict. IEEE Transactions on Systems, Man, and Cybernetics: Systems, 44(7), $834-850$. http://doi.org/10.1109/TSMC.2013.2282314 
Campennì, M., \& Schino, G. (2014). Partner choice promotes cooperation: the two faces of testing with agent-based models. Journal of Theoretical Biology, 344, 49-55. http://doi.org/10.1016/j.jtbi.2013.11.019

Chavali, A. K., Gianchandani, E. P., Tung, K. S., Lawrence, M. B., Peirce, S. M., \& Papin, J. A. (2008). Characterizing emergent properties of immunological systems with multi-cellular rule-based computational modeling. Trends in Immunology, 29(12), 589-99. http://doi.org/10.1016/j.it.2008.08.006

Chhetri, N., \& Nyaupane, G. P. (2009). Vulnerability to climate change of nature-based tourism in the Nepalese Himalayas. Tourism Geographies, 11(1), 95-119. http://doi.org/Vulnerability to climate change of nature-based tourism in the Nepalese Himalayas

Christensen, M., Rayamajhi, S., \& Meilby, H. (2009). Balancing fuelwood and biodiversity concerns in rural Nepal. Ecological Modelling, 220(4), 522-532. http://doi.org/10.1016/j.ecolmodel.2008.10.014

Collins, M., Booth, B. B. B., Harris, G. R., Murphy, J. M., Sexton, D. M. H., \& Webb, M. J. (2006). Towards quantifying uncertainty in transient climate change. Climate Dynamics, 27(2-3), 127-147. http://doi.org/10.1007/s00382-006-0121-0

Couclelis, H. (2001). Why I no longer work with agents: a challenge for ABMs of human environment interactions. In D. C. Parker, T. Berger, \& S. M. Manson (Eds.), Meeting the challenge of complexity: proceedings of a special workshop on landuse/land-cover change (pp. 14-16). Irvine: Center for Spatially Integrated Social 
Science, University of California at Santa Barbara. Retrieved from http://www.csiss.org/events/other/agent-based/additional/proceedings.pdf

Darbyshire, R., Webb, L., Goodwin, I., \& Barlow, E. W. R. (2014). Challenges in predicting climate change impacts on pome fruit phenology. International Journal of Biometeorology, 58(6), 1119-1133.

Devkota, R. P. (2014). Climate change: trends and people's perception in Nepal. Journal of Environmental Protection, 05(04), 255-265. http://doi.org/10.4236/jep.2014.54029

DFRS (Department of Forest Research and Survey), \& FRA (Forest Resource Assessment). (2014). Data needs assessment, forest resource assessment Nepal project, technical report no. 2. Kathmandu. Retrieved from http://www.franepal.org/wpcontent/uploads/downloads/publications/DataNeedsAssessmentReport2010_Final Approved_4April2014_Final.pdf

Dietrich, W. E., Bellugi, D. G., Sklar, L. S., Stock, J. D., Heimsath, A. M., \& Roering, J. J. (2003). Geomorphic transport laws for predicting landscape form and dynamics. In P. R. Wilcock \& R. M. Iverson (Eds.), Prediction in Geomorphology (Vol. 135, pp. 1-30). Washington, D. C.: American Geophysical Union. http://doi.org/10.1029/GM135

Ehrhardt-Martinez, K. (1998). Social determinants of deforestation in developing countries: a cross-national study. Social Forces, 77(2), 567 - 586. http://doi.org/10.1093/sf/77.2.567 
Epstein, J. M. (1999). Agent-based computational models and generative social science. Complexity, 4(5), $41-60$.

Epstein, J. M. (2006). Generative social science: studies in agent-based computational modeling. Princeton: Princeton University Press.

Epstein, J. M. (2009). Modelling to contain pandemics. Nature, 460(7256), 687. http://doi.org/10.1038/460687a

Epstein, J. M., \& Axtell, R. (1996). Growing artificial societies: social science from the bottom up. Washington: Brookings Institution Press. Retrieved from https://books.google.com/books?id=xXvelSs2caQC\&pgis=1

Eriksson, M., JianChu, X., Shrestha, A. B., Vaidya, R. A., Nepal, S., \& Sandström, K. (2009). The changing Himalayas: impact of climate change on water resources and livelihoods in the greater Himalayas. Kathmandu, Nepal: International Centre for Integrated Mountain Development (ICIMOD). Retrieved from http://www.cabdirect.org/abstracts/20093086376.html;jsessionid=9370528E078D A1E5A4CDCF118C74F81B

Evans, T. P., \& Kelley, H. (2004). Multi-scale analysis of a household level agent-based model of landcover change. Journal of Environmental Management, 72(1-2), 5772. http://doi.org/10.1016/j.jenvman.2004.02.008

Fairhead, J., \& Leach, M. (1996). Misreading the African landscape: society and ecology in a forest-savanna mosaic. New York: Cambridge University Press. Retrieved from https://books.google.com/books?id=CkGl2V-or_UC\&pgis=1 
FAO (Food and Agricultural Organization of the United Nations). (2009). Nepal forestry outlook study, Asia-Pacific forestry sector outlook study II (No. II/WP/2009/05). Bangkok. Retrieved from http://www.fao.org/docrep/014/am250e/am250e00.pdf

Fearnside, P. M. (1985). Environmental change and deforestation in the Brazilian Amazon. In J. Hemming (Ed.), Change in the Amazon Basin: man's impact on forests and rivers (pp. 70-89). Manchester: Manchester University Press.

Florent, Q., \& Enrico, B. (2015). Combining agent-based modeling and life cycle assessment for the evaluation of mobility policies. Environmental Science \& Technology, 49(3), 1744-1751. http://doi.org/10.1021/es5060868

Fox, J. (1993). Forest resources in a Nepali village in 1980 and 1990: the positive influence of population growth. Mountain Research and Development, 13(1), 8998.

Garmestani, A. S. (2014). Sustainability science: accounting for nonlinear dynamics in policy and social-ecological systems. Clean Technologies and Environmental Policy, 16(4), 731-738. http://doi.org/10.1007/s10098-013-0682-7

Gilani, H., Shrestha, H. L., Murthy, M. S. R., Phuntso, P., Pradhan, S., Bajracharya, B., \& Shrestha, B. (2015). Decadal land cover change dynamics in Bhutan. Journal of Environmental Management, 148, 91-100. http://doi.org/10.1016/j.jenvman.2014.02.014

Graciani Rodrigues, C. C., Espíndola, A. L., \& Penna, T. J. P. (2015). An agent-based computational model for tuberculosis spreading on age-structured populations. 
Physica A: Statistical Mechanics and Its Applications, 428, 52-59. http://doi.org/10.1016/j.physa.2015.02.027

Grimm, V., Berger, U., DeAngelis, D. L., Polhill, G. J., Giske, J., \& Railsback, S. F. (2010). The ODD protocol: A review and first update. Ecological Modelling, 221(23), 2760-2768. http://doi.org/10.1016/j.ecolmodel.2010.08.019

Grimm, V., \& Railsback, S. F. (2006). Agent-based models in ecology: patterns and alternative theories of adaptive behaviour. In F. C. Billari, T. Fent, A. Prskawetz, \& J. Scheffran (Eds.), Agent-Based Computational Modelling (pp. 139-152). Heidelberg: Physica-Verlag HD. http://doi.org/10.1007/3-7908-1721-X

Hawkins, E., \& Sutton, R. (2011). The potential to narrow uncertainty in projections of regional precipitation change. Climate Dynamics, 37(1), 407-418. http://doi.org/10.1007/s00382-010-0810-6

Hayes, T., \& Ostrom, E. (2005). Conserving the world's forests: are protected areas the only way. Indiana Law Review, 38(3), 595.

Henderson-Sellers, A., \& Gornitz, V. (1984). Possible climatic impacts of land cover transformations, with particular emphasis on tropical deforestation. Climatic Change, 6(3), 231-257.

Holland, J. H. (1992). Complex adaptive systems. Daedalus, 121(1), 17-30.

Holland, J. H. (1995). Hidden order: how adaptation builds complexity. Cambridge: Perseus Books. 
Hu, Y., Maskey, S., \& Uhlenbrook, S. (2013). Downscaling daily precipitation over the Yellow River source region in China: a comparison of three statistical downscaling methods. Theoretical and Applied Climatology, 112(3-4), 447-460. http://doi.org/10.1007/s00704-012-0745-4

INSE (International Network for Sustainable Energy). (2005). National energy situation survey report Nepal- focus on renewable energy \& poverty reduction. Kathmandu. Retrieved from www.inforse.org/asia/word_docs/Nepal-sust-energypoverty.doc

IPCC (Intergovernmental Panel on Climate Change). (2007a). Climate change 2007: the physical science basis. Contribution of working group I to the fourth assessment report of the Intergovernmental Panel on Climate Change. Cambridge. Retrieved from http://www.ipcc.ch/pdf/assessment-report/ar4/wg1/ar4_wg1_full_report.pdf

IPCC (Intergovernmental Panel on Climate Change). (2007b). The fourth assessment report: climate change 2007, synthesis report. Cambridge. Retrieved from https://www.ipcc.ch/pdf/assessment-report/ar4/wg2/ar4_wg2_full_report.pdf

Janmaat, J. A., \& Lapp, S. L. (2014). Nepali village model. CoMSES Computational Model Library. Retrieved from https://www.openabm.org/model/4187/version/1

Kandel, P. (2010). Forest resource assessment in Nepal: an assessment of data needs. Kathmandu. Retrieved from http://www.forestrynepal.org/images/publications/Data_needs_final.pdf 
Karki, R., \& Gurung, A. (2012). An overview of climate change and its impact on agriculture: a review from least developing country, Nepal. International Journal of Ecosystem, 2(2), 19-24. http://doi.org/10.5923/j.ije.20120202.03

Kaul, H., Cui, Z., \& Ventikos, Y. (2013). A multi-paradigm modeling framework to simulate dynamic reciprocity in a bioreactor. PLoS ONE, 8(3), e59671. http://doi.org/10.1371/journal.pone.0059671

Kaul, H., \& Ventikos, Y. (2013). Investigating biocomplexity through the agent-based paradigm. Briefings in Bioinformatics, 16(1), 137-152. http://doi.org/10.1093/bib/bbt077

Khadka, M., Karki, S., Karky, B. S., Kotru, R., \& Darjee, K. B. (2014). Gender equality challenges to the REDD+ initiative in Nepal. Mountain Research and Development, 34(3), 197-207. http://doi.org/10.1659/MRD-JOURNAL-D-1300081.1

Koschke, L., Fürst, C., Frank, S., \& Makeschin, F. (2012). A multi-criteria approach for an integrated land-cover-based assessment of ecosystem services provision to support landscape planning. Ecological Indicators, 21, 54-66. http://doi.org/10.1016/j.ecolind.2011.12.010

Lambin, E. F., Geist, H. J., \& Lepers, E. (2003). Dynamics of land-use and land-cover change in tropical regions. Annual Review of Environment and Resources, 28, 205-241. http://doi.org/10.1146/annurev.energy.28.050302.105459

Langevin, J., Wen, J., \& Gurian, P. L. (2015). Simulating the human-building interaction: Development and validation of an agent-based model of office occupant 
behaviors. Building and Environment, 88, 27-45.

http://doi.org/10.1016/j.buildenv.2014.11.037

Lempert, R. (2002). Agent-based modeling as organizational and public policy simulators. Proceedings of the National Academy of Sciences of the United States of America, 99 Suppl 3(90003), 7195-7196.

http://doi.org/10.1073/pnas.072079399

Levin, S. A. (1998). Ecosystems and the biosphere as complex adaptive systems. Ecosystems, 1(5), 431-436. http://doi.org/10.1007/s100219900037

Levin, S. A. (1999). Fragile dominion: complexity and the commons. New York: Basic Books.

Levin, S. A. (2003). Complex adaptive systems: exploring the known, the unknown and the unknowable. Bulletin, New Series, of the American Mathematical Society, 40(1), 3-20. http://doi.org/10.1090/S0273-0979-02-00965-5

Levin, S. A., Xepapadeas, T., Crépin, A.-S., Norberg, J., De Zeeuw, A., Folke, C., ... Walker, B. (2013). Social-ecological systems as complex adaptive systems: modeling and policy implications. Environment and Development Economics, 18(2), 111-132. http://doi.org/10.1017/S1355770X12000460

Liu, J., Dietz, T., Carpenter, S. R., Alberti, M., Folke, C., Moran, E., ... Taylor, W. W. (2007). Complexity of coupled human and natural systems. Science (New York, N.Y.), 317(5844), 1513-1516. http://doi.org/10.1126/science.1144004 
Malanson, G. P., Zeng, Y., \& Walsh, S. J. (2006). Complexity at advancing ecotones and frontiers. Environment and Planning A, 38(4), 619-632. http://doi.org/10.1068/a37340

Malla, G. (2008). Climate change and its impact on Nepalese agriculture. Journal of Agriculture and Environment, 9, 62-71. http://doi.org/10.3126/aej.v9i0.2119

Marin, A. (2010). Riders under storms: contributions of nomadic herders’ observations to analysing climate change in Mongolia. Global Environmental Change, 20(1), 162-176. http://doi.org/10.1016/j.gloenvcha.2009.10.004

Maskey, S., Uhlenbrook, S., \& Ojha, S. (2011). An analysis of snow cover changes in the Himalayan region using MODIS snow products and in-situ temperature data. Climatic Change, 108(1-2), 391-400. http://doi.org/10.1007/s10584-011-0181-y

Matthews, R. B., Gilbert, N. G., Roach, A., Polhill, G. J., \& Gotts, N. M. (2007). Agentbased land-use models: a review of applications. Landscape Ecology, 22(10), 1447-1459. http://doi.org/10.1007/s10980-007-9135-1

Mena, C. F., Walsh, S. J., Frizzelle, B. G., Xiaozheng, Y., \& Malanson, G. P. (2011). Land use change on household farms in the Ecuadorian Amazon: design and implementation of an agent-based model. Applied Geography, 31(1), 210-222. http://doi.org/10.1016/j.apgeog.2010.04.005

Miller, K. D. (2015). Agent-based modeling and organization studies: a critical realist perspective. Organization Studies, 36(2), 175-196.

http://doi.org/10.1177/0170840614556921 
Molden, D., \& Sharma, E. (2013). ICIMOD’s strategy for delivering high-quality research and achieving impact for sustainable mountain development. Mountain Research and Development, 33(2), 179-183. http://doi.org/10.1659/MRDJOURNAL-D-13-00018.1

Mudimu, E., \& Engelbrecht, G. N. (2015). Agent-based model for social and sexual partnerships formation. Adaptive Behavior, 23(1), 34-49. http://doi.org/10.1177/1059712314547709

Nagendra, H., \& Ostrom, E. (2007). Institutions, collective action and effective forest management: learning from studies in Nepal. In J. Pretty, A. S. Ball, T. Benton, J. Guivant, D. R. Lee, D. Orr, ... H. Ward (Eds.), The SAGE handbook of environment and society (pp. 578-590). London: SAGE Publications Ltd. http://doi.org/http://dx.doi.org/10.4135/9781848607873.n39

NCVST (Nepal Climate Vulnerability Team). (2009). Vulnerability through the eyes of vulnerable: climate change induced uncertainties and Nepal's development predicaments. Boulder; Kathmandu. Retrieved from http://i-s-et.org/resources/major-program-reports/vulnerability-through-the-eyes-ofvulnerable.html

Nelson, T., Coops, N., Wulder, M., Perez, L., Fitterer, J., Powers, R., \& Fontana, F. (2014). Predicting climate change impacts to the Canadian Boreal forest. Diversity, 6(1), 133-157. http://doi.org/10.3390/d6010133

Niraula, R. R., Gilani, H., Pokharel, B. K., \& Qamer, F. M. (2013). Measuring impacts of community forestry program through repeat photography and satellite remote 
sensing in the Dolakha district of Nepal. Journal of Environmental Management, 126, 20-9. http://doi.org/10.1016/j.jenvman.2013.04.006

Norgaard, R. B. (1994). Development betrayed: the end of progress and a coevolutionary revisioning of the future. London: Routledge.

Ojha, H. R., Ghimire, S., Pain, A., Nightingale, A., Khatri, D. B., \& Dhungana, H. (2015). Policy without politics: technocratic control of climate change adaptation policy making in Nepal. Climate Policy, 1-19. http://doi.org/10.1080/14693062.2014.1003775

Olesen, J. E., \& Bindi, M. (2002). Consequences of climate change for European agricultural productivity, land use and policy. European Journal of Agronomy, 16(4), 239-262. http://doi.org/10.1016/S1161-0301(02)00004-7

Palazzoli, I., Maskey, S., Uhlenbrook, S., Nana, E., \& Bocchiola, D. (2015). Impact of prospective climate change on water resources and crop yields in the Indrawati basin, Nepal. Agricultural Systems, 133, 143-157. http://doi.org/10.1016/j.agsy.2014.10.016

Parker, D. C., Manson, S. M., \& Berger, T. (2001). Potential strengths and appropriate roles for ABM/LUCC. In D. C. Parker, T. Berger, \& S. M. Manson (Eds.), Meeting the challenge of complexity: proceedings of a special workshop on landuse/land-cover change (pp. 17-24). Irvine: Center for Spatially Integrated Social Science, University of California at Santa Barbara. Retrieved from http://www.csiss.org/events/other/agent-based/additional/proceedings.pdf 
Parry, M. L., Rosenzweig, C., Iglesias, A., Livermore, M., \& Fischer, G. (2004). Effects of climate change on global food production under SRES emissions and socioeconomic scenarios. Global Environmental Change, 14(1), 53-67. http://doi.org/10.1016/j.gloenvcha.2003.10.008

Pérez, I., \& Janssen, M. A. (2015). The effect of spatial heterogeneity and mobility on the performance of social-ecological systems. Ecological Modelling, 296, 1-11. http://doi.org/10.1016/j.ecolmodel.2014.10.014

Poteete, A., \& Ostrom, E. (2004). An institutional approach to the study of forest resources. In J. Poulsen (Ed.), Human impacts on tropical forest biodiversity and genetic resources. New York: Oxford University Press.

Purnomo, H., Mendoza, G. A., Prabhu, R., \& Yasmi, Y. (2005). Developing multistakeholder forest management scenarios: a multi-agent system simulation approach applied in Indonesia. Forest Policy and Economics, 7(4), 475-491. http://doi.org/10.1016/j.forpol.2003.08.004

R Core Team. (2014). R: a language and environment for statistical computing. Vienna: R Foundation for Statistical Computing. Retrieved from http://www.r-project.org/

Rahmandad, H., \& Sterman, J. (2008). Heterogeneity and network structure in the dynamics of diffusion: comparing agent-based and differential equation models. Management Science, 54(5), 998-1014. http://doi.org/10.1287/mnsc.1070.0787

Rai, M. (2007). Climate change and agriculture: a Nepalese case. Journal of Agriculture and Environment, 8, 92-95. http://doi.org/10.3126/aej.v8i0.732 
Railsback, S. F., \& Grimm, V. (2012). Agent-based and individual-based modeling: a practical introduction. Princeton: Princeton University Press.

Richards, J. F., \& Tucker, R. P. (1988). World deforestation in the twentieth century. Durham, NC: Duke University Press.

Rindfuss, R. R., Entwisle, B., Walsh, S. J., An, L., Badenoch, N., Brown, D. G., ... Verburg, P. H. (2008). Land use change: complexity and comparisons. Journal of Land Use Science, 3(1), 1-10. http://doi.org/10.1080/17474230802047955

Riolo, R. L., Cohen, M. D., \& Axelrod, R. M. (2001). Evolution of cooperation without reciprocity. Nature, 414(6862), 441-443. http://doi.org/10.1038/35106555

Rolfe, J., Bennett, J., \& Louviere, J. (2000). Choice modelling and its potential application to tropical rainforest preservation. Ecological Economics, 35(2), 289302. http://doi.org/10.1016/S0921-8009(00)00201-9

Salle, I. L. (2015). Modeling expectations in agent-based models — an application to central bank’s communication and monetary policy. Economic Modelling, 46, 130-141. http://doi.org/10.1016/j.econmod.2014.12.040

Saqalli, M., Bielders, C. L., Gerard, B., \& Defourny, P. (2010). Simulating rural environmentally and socio-economically constrained multi-activity and multidecision societies in a low-data context: a challenge through empirical agentbased modeling. Journal of Artificial Societies and Social Simulation, 13(2), 1. 
Sauvageau, G., \& Frayret, J.-M. (2015). Waste paper procurement optimization: an agent-based simulation approach. European Journal of Operational Research, 242(3), 987-998. http://doi.org/10.1016/j.ejor.2014.10.035

Shivakoti, G. P., \& Ostrom, E. (2008). Facilitating decentralized policies for sustainable governance and management of forest resources in Asia. In E. L. Webb \& G. P. Shivakoti (Eds.), Decentralization, forest and rural communities: policy outcomes in South and Southeast Asia (pp. 292-310). New Delhi: SAGE Publications.

Singh, S. P., Bassignana-Khadka, I., Karky, B. S., \& Sharma, E. (2011). Climate change in the Hindu Kush-Himalayas: the state of current knowledge. (S. P. Singh, I. Bassignana-Khadka, \& B. Karky, Eds.). Kathmandu: International Centre for Integrated Mountain Development (ICIMOD).

Smajgl, A., \& Barreteau, O. (2013). Empirical agent-based modelling-- challenges and solutions. (A. Smajgl \& O. Barreteau, Eds.). New York; Heidelberg; Dordrecht; London: Springer. http://doi.org/10.1007/978-1-4614-6134-0

Thapa, G. J., Wikramanayake, E., \& Forrest, J. (2013). Climate-change impacts on the biodiversity of the Terai Arc landscape and the Chitwan-Annapurna landscape. Kathmandu. Retrieved from http://awsassets.panda.org/downloads/annex_12_12_report_climate_change_im pacts_on_the_biodiversity_of_tal_and_chal_1.pdf

Thorne, B. C., Bailey, A. M., DeSimone, D. W., \& Peirce, S. M. (2007). Agent-based modeling of multicell morphogenic processes during development. Birth Defects 
Research. Part C, Embryo Today: Reviews, 81(4), 344-53.

http://doi.org/10.1002/bdrc.20106

Thorne, B. C., Bailey, A. M., \& Peirce, S. M. (2007). Combining experiments with multicell agent-based modeling to study biological tissue patterning. Briefings in Bioinformatics, 8(4), 245-57. http://doi.org/10.1093/bib/bbm024

Turkay, C., Koc, E., \& Balcisoy, S. (2011). Integrating information theory in agent-based crowd simulation behavior models. The Computer Journal, 54(11), 1810-1820. http://doi.org/10.1093/comjnl/bxr014

Uddin, K., Shrestha, H. L., Murthy, M. S. R., Bajracharya, B., Shrestha, B., Gilani, H., ... Dangol, B. (2015). Development of 2010 national land cover database for the Nepal. Journal of Environmental Management, 148, 82-90. http://doi.org/10.1016/j.jenvman.2014.07.047

UNDP (United Nations Development Programme). (2014). Nepal climate change support programme. Retrieved March 10, 2015, from http://www.np.undp.org/content/nepal/en/home/operations/projects/environment_ and_energy/nccsp/home.html

Vallino, E. (2014). The tragedy of the park: an agent-based model of endogenous and exogenous institutions for forest management. Ecology and Society, 19(1), 35. http://doi.org/10.5751/ES-06242-190135

Varughese, G. (2000). Population and forest dynamics in the hills of Nepal: institutional remedies by rural communities. In C. C. Gibson, M. A. McKean, \& E. Ostrom 
(Eds.), People and forests: communities, institutions, and governance (pp. 193227). Cambridge: MIT Press.

Varughese, G., \& Ostrom, E. (2001). The contested role of heterogeneity in collective action: some evidence from community forestry in Nepal. World Development, 29(5), 747-765. http://doi.org/10.1016/S0305-750X(01)00012-2

Veldkamp, A., \& Lambin, E. F. (2001). Predicting land-use change. Agriculture, Ecosystems \& Environment, 85(1), 1-6. http://doi.org/10.1016/S01678809(01)00199-2

Waldrop, M. M. (1992). Complexity: the emerging science at the edge of order and chaos. New York: Simon \& Schuster.

Walsh, S. J., Messina, J. P., Mena, C. F., Malanson, G. P., \& Page, P. H. (2008). Complexity theory, spatial simulation models, and land use dynamics in the Northern Ecuadorian Amazon. Geoforum, 39(2), 867-878. http://doi.org/10.1016/j.geoforum.2007.02.011

Wandersee, S. M., An, L., López-Carr, D., \& Yang, Y. (2012). Perception and decisions in modeling coupled human and natural systems: a case study from Fanjingshan National Nature Reserve, China. Ecological Modelling, 229, 37-49. http://doi.org/10.1016/j.ecolmodel.2011.08.004

Waring, T. M., Goff, S., \& Smaldino, P. E. (2015). Evolving the core design principles: the coevolution of institutions and sustainable practices. In Press. Retrieved from https://computationalsocialscience.org/wpcontent/uploads/2013/08/WaringEtAl2013.pdf 
Wilensky, U., \& Rand, W. (2007). Making models match: replicating an agent-based model. Journal of Artificial Societies and Social Simulation, 10(4), 2.

Windrum, P., Fagiolo, G., \& Moneta, A. (2007). Empirical validation of agent-based models: Alternatives and prospects. Journal of Artificial Societies and Social Simulation, 10(2), 8.

World Bank. (2013). World Bank indicators - Nepal - land use, trading economics. Retrieved June 15, 2014, from http://www.tradingeconomics.com/nepal/forestarea-percent-of-land-area-wb-data.html

Wunder, M., Suri, S., \& Watts, D. (2013). Empirical agent based models of cooperation in public goods games. In Proceedings of the fourteenth ACM conference on electronic commerce (pp. 891-908). New York: ACM. http://doi.org/10.1145/2482540.2482586

Wurzer, G., Kowarik, K., \& Reschreiter, H. (2015). Agent-based modeling and simulation in archaeology. (G. Wurzer, K. Kowarik, \& H. Reschreiter, Eds.). Cham; Heidelberg; New York; Dordrecht; London: Springer International Publishing. http://doi.org/10.1007/978-3-319-00008-4

Zellner, M. L., Theis, T. L., Karunanithi, A. T., Garmestani, A. S., \& Cabezas, H. (2008). A new framework for urban sustainability assessments: linking complexity, information and policy. Computers, Environment and Urban Systems, 32(6), 474488. http://doi.org/10.1016/j.compenvurbsys.2008.08.003

Zhang, H., Jin, X., Wang, L., Zhou, Y., \& Shu, B. (2015). Multi-agent based modeling of spatiotemporal dynamical urban growth in developing countries: simulating future 
scenarios of Lianyungang city, China. Stochastic Environmental Research and Risk Assessment, 29(1), 63-78. http://doi.org/10.1007/s00477-014-0942-z

Zvoleff, A., \& An, L. (2014). The effect of reciprocal connections between demographic decision making and land use on decadal dynamics of population and land-use change. Ecology and Society, 19(2), 122-167. http://doi.org/10.5751/ES-06243190231 


\section{CONCLUSION}

The remote sensing analysis in Chapter 1 suggests that forest conditions within CNP’s buffer zone have begun to stabilize between 2005 and 2013. Forests have seen significant regeneration in the study area, a trend consistent with other reports of current rates of deforestation and forest degradation in Nepal that suggest a cessation in forest loss on a national level. Indeed, the total percentage of forest cover in Nepal was stable at 25.4\% in 2005 (REDD, 2014), and World Bank (2013) data indicate consistent levels in 2009, 2010, and 2011. While there have not been many recent forest cover NDVI analyses done for our study area, our results partially coincide with the results of another NDVI deforestation study conducted in the Chitwan district adjacent to CNP by Panta et al. (2008). That study found that between 1989 and 2001, forest cover in the Chitwan District fell 7.95 percent, whereas our study found that for all VDCs in the buffer zone of CNP, forest cover fell 9.9 percent between 1989 and 2005.

The cessation of forest loss in Nepal is likely due to a combination of factors. We suggest here that decentralized forest management institutions such as community forestry have played an important role in not just slowing, but halting and possibly reversing forest loss and degradation in the buffer zone of CNP. Indeed, the resourcedependent rural populations of Nepal are increasingly becoming involved in the management of local forest resources, and the number of CFUGs is continually growing.

In Chapter 2, we sought to explore how household attitudes toward forest conservation-related behaviors correlated with empirical forest cover trends. We also sought to better understand the socio-demographic variables that influence supportive attitudes toward forest conservation-related behaviors in our two study locations. 
Supportive attitudes included having a need for forests in their community, being cognizant of current forest conditions, supporting their local CFUG, being willing to work with NGOs that promote sustainable forest practices, supporting forest-related policies and management institutions in Nepal, and recognizing the importance of energy-efficient technologies such as biogas in reducing forest degradation.

Of the 36 VDCs in the buffer zone of CNP, Bachauli and Narayani are on opposite ends of the spectrum in terms of reversing forest trends between 2005 and 2013. Bachauli has not just ceased the rapid rate of forest loss that it experienced prior to 2005, but in the last decade it has reversed it to a rate of significant regrowth. The opposite is true for Narayani. The relative success of other communities in Nepal in terms of forest conservation and community forestry varies as well (see, e.g., Gautam \& Shivakoti, 2005). Not surprisingly, there is a clear difference between the overall attitudes of respondents toward forest conservation in Bachauli and Narayani, and it appears that attitudes between the areas of interest reflect forest cover trends-indeed, they are distinctly different, with attitudes in Bachauli being more supportive of forest conservation.

The results of Chapter 3 suggest that implementing new policies aimed at improving individual attitudes toward forest conservation-oriented behaviors would have a dramatic effect on the forest cover in Bachauli over time. The ability for villages to cooperate and mimic their neighbors, regardless of varying probabilities of occurrence, will likely have little effect on forest cover after 25 years. Additionally, the rate at which population is growing within this SES has a significant effect on forest conservation. 
Despite clear strengths, there are challenges with modeling forest conservation dynamics and LULCC in Bachuli at different scales.

We suggest two areas of need that should be considered as Nepal develops its new Forestry Sector Strategy. The first is to ensure increased distribution of forest-related rights, responsibilities, and revenue for poorer, underrepresented populations. Participatory forest management has proven to be effective in reducing forest loss in Nepal, and it is imperative that women, the poor, and other disadvantaged groups share in these responsibilities and benefits. The second is for government institutions and representatives to become more transparent, consistent, and considerate in their management practices and relationships with communities and CFUGs. Although equal participation alone is not a panacea (KC et al., 2014 citing Cohen \& Uphoff, 1980), the state of forests in Nepal can only improve if better relationships are built between all stakeholders.

We conclude with a quote from Elinor Ostrom's Nobel Prize Acceptance speech (later published in The American Economic Review), in which she eloquently states:

The most important lesson for public policy analysis derived from the intellectual journey I have outlined here is that humans have a more complex motivational structure and more capability to solve social dilemmas than posited in earlier rational-choice theory. Designing institutions to force (or nudge) entirely self-interested individuals to achieve better outcomes has been the major goal posited by policy 
analysts for governments to accomplish for much of the past half century. Extensive empirical research leads me to argue that instead, a core goal of public policy should be to facilitate the development of institutions that bring out the best in humans. We need to ask how diverse polycentric institutions help or hinder the innovativeness, learning, adapting, trustworthiness, levels of cooperation of participants, and the achievement of more effective, equitable, and sustainable outcomes at multiple scales (Ostrom, 2010, p. 664-5).

\section{LITERATURE CITED}

Cohen, J. M., \& Uphoff, N. T. (1980). Participation’s place in rural development: seeking clarity through specificity. World Development, 8(3), 213-235. http://doi.org/10.1016/0305-750X(80)90011-X

Gautam, A. P., Shivakoti, G. P., \& Webb, E. L. (2004). A review of forest policies, institutions, and changes in the resource condition in Nepal. International Forestry Review, 6(2), 136-148. http://doi.org/10.1505/ifor.6.2.136.38397

KC, B., Stainback, G. A., \& Chhetri, B. B. K. (2014). Community users' and experts' perspective on community forestry in Nepal: a SWOT-AHP analysis. Forests, Trees and Livelihoods, 23(4), 217-231.

http://doi.org/10.1080/14728028.2014.929982 
Ostrom, E. (2010). Beyond markets and states: polycentric governance of complex economic systems. The American Economic Review, 100(3), 641-672. http://doi.org/10.1257/aer.100.3.641

Panta, M., Kim, K., \& Joshi, C. (2008). Temporal mapping of deforestation and forest degradation in Nepal: Applications to forest conservation. Forest Ecology and Management, 256(9), 1587-1595. http://doi.org/10.1016/j.foreco.2008.07.023

REDD (United Nations Collaborative Initiative on Reducing Emissions from Deforestation and Forest Degradation). (2014). REDD in Nepal. Retrieved October 1, 2014, from http://theredddesk.org/countries/nepal

World Bank. (2013). World Bank indicators - Nepal - land use, trading economics. Retrieved June 15, 2014, from http://www.tradingeconomics.com/nepal/forestarea-percent-of-land-area-wb-data.html 


\section{BIBLIOGRAPHY}

Achard, F., Eva, H. D., Stibig, H.-J., Mayaux, P., Gallego, J., Richards, T., \& Malingreau, J.-P. (2002). Determination of deforestation rates of the world's humid tropical forests. Science (New York, N.Y.), 297(5583), 999-1002.

Acharya, U., Petheram, R. J., \& Reid, R. (2004). Concepts and perceptions of biodiversity in community forestry, Nepal. Small-Scale Forest Economics, Management and Policy, 3(3), 401-410. http://doi.org/10.1007/s11842-004-00288

Adhikari, B., Di Falco, S., \& Lovett, J. C. (2004). Household characteristics and forest dependency: Evidence from common property forest management in Nepal. Ecological Economics, 48(2), 245-257. http://doi.org/10.1016/j.ecolecon.2003.08.008

Agarwal, A., Babel, M. S., \& Maskey, S. (2014). Analysis of future precipitation in the Koshi River Basin, Nepal. Journal of Hydrology, 513, 422-434. http://doi.org/10.1016/j.jhydrol.2014.03.047

Agrawal, A. (1995). Population pressure $=$ forest degradation: an oversimplistic equation? Unasylva, 181(46), 50-58.

Agrawal, A., \& Gupta, K. (2005). Decentralization and participation: the governance of common pool resources in Nepal's Terai. World Development, 33(7), 1101-1114. http://doi.org/10.1016/j.worlddev.2005.04.009

Agrawal, A., \& Ostrom, E. (2001). Collective action, property rights, and decentralization in resource use in India and Nepal. Politics Society Vol. 29, No. 485, 29(4), 31. http://doi.org/10.1177/0032329201029004002

Agrawal, A., \& Ostrom, E. (2006). Political science and conservation biology: A dialog of the deaf. Conservation Biology, 20(3), 681-682. http://doi.org/10.1111/j.15231739.2006.00468.x

Agrawal, A., \& Ostrom, E. (2008). Decentralization and community-based forestry: learning from experience. In E. L. Webb \& G. P. Shivakoti (Eds.), Decentralization, forests and rural communities: policy outcomes in Southeast Asia (pp. 44-67). New Delhi, India: Sage Publications.

Agrawal, A., \& Ribot, J. C. (1999). Accountability in decentralization: a framework with South Asian and West African cases. The Journal of Developing Areas, 33(4), 473-502.

An, L. (2012). Modeling human decisions in coupled human and natural systems: Review of agent-based models. Ecological Modelling, 229, 25-36.

http://doi.org/10.1016/j.ecolmodel.2011.07.010

An, L., He, G., Liang, Z., \& Liu, J. (2006). Impacts of demographic and socioeconomic factors on spatio-temporal dynamics of panda habitat. Biodiversity and Conservation, 15(8), 2343-2363. http://doi.org/10.1007/s10531-004-1064-6 
An, L., Linderman, M., Qi, J., \& Shortridge, A. (2005). Exploring complexity in a human-environment system: an agent-based spatial model for multidisciplinary and multiscale integration. The Annals of the Association of American Geographers, 95(1), 54-79. http://doi.org/10.1111/j.1467-8306.2005.00450.x

An, L., \& Liu, J. (2010). Long-term effects of family planning and other determinants of fertility on population and environment: agent-based modeling evidence from Wolong Nature Reserve, China. Population and Environment, 31(6), 427-459. http://doi.org/10.1007/s11111-010-0111-3

Anderies, J. M. (2015). Understanding the dynamics of sustainable social-ecological systems: human behavior, institutions, and regulatory feedback networks. Bulletin of Mathematical Biology, 77(2), 259 - 80. http://doi.org/10.1007/s11538-0140030-z

Andersson, K. P., \& Ostrom, E. (2008). Analyzing decentralized resource regimes from a polycentric perspective. Policy Sciences, 41(1), 71-93. http://doi.org/10.1007/s11077-007-9055-6

Arnold, J. E. M. (1992). Community forestry ten years in review. Rome.

Aryal, B. P., Regmi, H., Sah, S. N., Acharya, K., Rimal, U. H., \& Pahari, K. (2011). Crop situation update (a joint assessment of 2010 summer crops and outlook for 2011 winter crops). Retrieved from http://documents.wfp.org/stellent/groups/public/documents/ena/wfp234049.pdf

Axelrod, R. M. (1997). Advancing the art of simulation in the social sciences. Complexity, 3(2), 16 - 22. http://doi.org/10.1002/(SICI)10990526(199711/12)3:2<16::AID-CPLX4>3.0.CO;2-K

Axelrod, R. M., \& Cohen, M. D. (1999). Harnessing complexity: organizational implications of a scientific frontier. New York: Free Press.

Axtell, R., Axelrod, R. M., Epstein, J. M., \& Cohen, M. D. (1996). Aligning simulation models: a case study and results. Computational \& Mathematical Organization Theory, 1(2), 123-141. http://doi.org/10.1007/BF01299065

Azuajeu, F. (2011). Computational discrete models of tissue growth and regeneration. Briefings in Bioinformatics, 12(1), 64-77.

Bajracharya, B., Uddin, K., Chettri, N., Shrestha, B., \& Siddiqui, S. A. (2010). Understanding land cover change using a harmonized classification system in the Himalaya. Mountain Research and Development, 30(2), 143-156.

Bajracharya, D. (1983). Deforestation in the food/fuel context: historical and political perspectives from Nepal. Mountain Research and Development, 3(3), 227-240. http://doi.org/10.2307/3673017

Bakker, M. M., \& van Doorn, A. M. (2009). Farmer-specific relationships between land use change and landscape factors: Introducing agents in empirical land use modelling. Land Use Policy, 26(3), 809-817. 
Banskota, K., Sharma, B., Sharma, U., \& Rijal, A. (1996). Royal Chitwan National Park after twenty years: an assessment of values, threats, and opportunities. Kathmandu.

Baral, N., \& Heinen, J. T. (2007). Resources use, conservation attitudes, management intervention and park-people relations in the Western Terai landscape of Nepal. Environmental Conservation, 34(1), 64. http://doi.org/10.1017/S0376892907003670

Barber, J. S., Shivakoti, G. P., Axinn, W. G., \& Gajurel, K. (1997). Sampling strategies for rural settings: a detailed example from Chitwan Valley Family Study, Nepal. Nepal Population Journal, 6(5), 193-203.

Bausch, A. W. (2014). Evolving intergroup cooperation. Computational \& Mathematical Organization Theory, 20(4), 369 - 393. http://doi.org/10.1007/s10588-013-91701

Benoit, C., Jansson, M., Millar, A., \& Phillips, R. (2005). Community-academic research on hard-to-reach populations: benefits and challenges. Qualitative Health Research, 15(2), 263-282. http://doi.org/10.1177/1049732304267752

Berger, T. (2001). Agent-based spatial models applied to agriculture: a simulation tool for technology diffusion, resource use changes and policy analysis. In Agricultural Economics (Vol. 25, pp. 245-260).

Berkes, F., Colding, J., \& Folke, C. (2003). Navigating social-ecological systems: building resilience for complexity and change. New York, Cambridge, U.K: Cambridge University Press.

Berkes, F., Folke, C., \& Colding, J. (1998). Linking social and ecological systems: management practices and social mechanisms for building resilience. New York, Cambridge, UK: Cambridge University Press.

Bernard, R. H. (2002). Research methods in anthropology: qualitative and quantitative methods (3rd ed.). Walnut Creek: AltaMira Press.

Bharati, L., Gurung, P., Jayakody, P., Smakhtin, V., \& Bhattarai, U. (2014). The projected impact of climate change on water availability and development in the Koshi Basin, Nepal. Mountain Research and Development, 34(2), 118-130. Retrieved from http://dx.doi.org/10.1659/MRD-JOURNAL-D-13-00096.1

Bhatt, D., Maskey, S., Babel, M. S., Uhlenbrook, S., \& Prasad, K. C. (2014). Climate trends and impacts on crop production in the Koshi River basin of Nepal. Regional Environmental Change, 14(4), 1291-1301.

Bhattarai, K., Conway, D., \& Yousef, M. (2009). Determinants of deforestation in Nepal's Central Development Region. Journal of Environmental Management, 91(2), 471-488.

Bista, D. B. (1987). People of Nepal (5th ed.). Kathmandu: Ratna Pustak Bhandar. 
Bohra, P., \& Massey, D. S. (2009). Processes of internal and international migration from Chitwan, Nepal. International Migration Review, 43(3), 621-651.

Boserup, E. (1965). The conditions of agricultural growth : the economics of agrarian change under population pressure. Population Studies, 20(1), 1-108. http://doi.org/10.2307/2172620

Bristow, M., Fang, L., \& Hipel, K. W. (2014). Agent-based modeling of competitive and cooperative behavior under conflict. IEEE Transactions on Systems, Man, and Cybernetics: Systems, 44(7), $834-850$. http://doi.org/10.1109/TSMC.2013.2282314

Brower, B. (1991a). Crisis and conservation in Sagarmatha national park, Nepal. Society \& Natural Resources, 4(2), 151-163. http://doi.org/10.1080/08941929109380750

Brower, B. (1991b). Sherpa of Khumbu: people, livestock, and landscape (2nd ed.). Delhi: Oxford University Press.

Brower, B., \& Dennis, A. (1998). Grazing the forest, shaping the landscape? Continuing the debate about forest dynamics in Sagarmatha National Park. In K. Zimmerer \& K. Young (Eds.), Nature's geography: new lessons for conservation in developing countries (pp. 184-208). Madison: University of Wisconsin Press.

Budhathoki, P. (2004). Linking communities with conservation in developing countries: buffer zone management initiatives in Nepal. Oryx, 38(3). http://doi.org/10.1017/S0030605304000584

Campennì, M., \& Schino, G. (2014). Partner choice promotes cooperation: the two faces of testing with agent-based models. Journal of Theoretical Biology, 344, 49-55. http://doi.org/10.1016/j.jtbi.2013.11.019

Chakraborty, R. N. (2001). Stability and outcomes of common property institutions in forestry: evidence from the Terai region of Nepal. Ecological Economics, 36(2), 341-353. http://doi.org/10.1016/S0921-8009(00)00237-8

Chavali, A. K., Gianchandani, E. P., Tung, K. S., Lawrence, M. B., Peirce, S. M., \& Papin, J. A. (2008). Characterizing emergent properties of immunological systems with multi-cellular rule-based computational modeling. Trends in Immunology, 29(12), 589-99. http://doi.org/10.1016/j.it.2008.08.006

Chevan, A., \& Sutherland, M. (1991). Hierarchical parititioning. The American Statistician, 45(2), 90-96.

Chhetri, B. B. K., Lund, J. F., \& Nielsen, Ø. J. (2012). The public finance potential of community forestry in Nepal. Ecological Economics, 73, 113-121. http://doi.org/10.1016/j.ecolecon.2011.09.023

Chhetri, N., \& Nyaupane, G. P. (2009). Vulnerability to climate change of nature-based tourism in the Nepalese Himalayas. Tourism Geographies, 11(1), 95-119. http://doi.org/Vulnerability to climate change of nature-based tourism in the Nepalese Himalayas 
Christensen, M., Rayamajhi, S., \& Meilby, H. (2009). Balancing fuelwood and biodiversity concerns in rural Nepal. Ecological Modelling, 220(4), 522-532. http://doi.org/10.1016/j.ecolmodel.2008.10.014

Cohen, J. M., \& Uphoff, N. T. (1980). Participation's place in rural development: seeking clarity through specificity. World Development, 8(3), 213-235. http://doi.org/10.1016/0305-750X(80)90011-X

Collins, M., Booth, B. B. B., Harris, G. R., Murphy, J. M., Sexton, D. M. H., \& Webb, M. J. (2006). Towards quantifying uncertainty in transient climate change. Climate Dynamics, 27(2-3), 127-147. http://doi.org/10.1007/s00382-006-0121-0

Couclelis, H. (2001). Why I no longer work with agents: a challenge for ABMs of human environment interactions. In D. C. Parker, T. Berger, \& S. M. Manson (Eds.), Meeting the challenge of complexity: proceedings of a special workshop on landuse/land-cover change (pp. 14-16). Irvine: Center for Spatially Integrated Social Science, University of California at Santa Barbara. Retrieved from http://www.csiss.org/events/other/agent-based/additional/proceedings.pdf

Darbyshire, R., Webb, L., Goodwin, I., \& Barlow, E. W. R. (2014). Challenges in predicting climate change impacts on pome fruit phenology. International Journal of Biometeorology, 58(6), 1119-1133.

De Vaus, D. (2002). Surveys in social research (5th ed.). London: Routledge. http://doi.org/10.2307/2071069

DeVellis, R. F. (1991). Scale development: theory and applications. Newbury Park: Sage.

Devkota, R. P. (2014). Climate change: trends and people's perception in Nepal. Journal of Environmental Protection, 05(04), 255-265.

http://doi.org/10.4236/jep.2014.54029

DFRS (Department of Forest Research and Survey), \& FRA (Forest Resource Assessment). (2014). Data needs assessment, forest resource assessment Nepal project, technical report no. 2. Kathmandu. Retrieved from http://www.franepal.org/wpcontent/uploads/downloads/publications/DataNeedsAssessmentReport2010_Final Approved_4April2014_Final.pdf

Dietrich, W. E., Bellugi, D. G., Sklar, L. S., Stock, J. D., Heimsath, A. M., \& Roering, J. J. (2003). Geomorphic transport laws for predicting landscape form and dynamics. In P. R. Wilcock \& R. M. Iverson (Eds.), Prediction in Geomorphology (Vol. 135, pp. 1-30). Washington, D. C.: American Geophysical Union. http://doi.org/10.1029/GM135

Ehrhardt-Martinez, K. (1998). Social determinants of deforestation in developing countries: a cross-national study. Social Forces, 77(2), 567 - 586. http://doi.org/10.1093/sf/77.2.567 
Epstein, J. M. (1999). Agent-based computational models and generative social science. Complexity, 4(5), $41-60$.

Epstein, J. M. (2006). Generative social science: studies in agent-based computational modeling. Princeton: Princeton University Press.

Epstein, J. M. (2009). Modelling to contain pandemics. Nature, 460(7256), 687. http://doi.org/10.1038/460687a

Epstein, J. M., \& Axtell, R. (1996). Growing artificial societies: social science from the bottom up. Washington: Brookings Institution Press. Retrieved from https://books.google.com/books?id=xXvelSs2caQC\&pgis=1

Eriksson, M., JianChu, X., Shrestha, A. B., Vaidya, R. A., Nepal, S., \& Sandström, K. (2009). The changing Himalayas: impact of climate change on water resources and livelihoods in the greater Himalayas. Kathmandu, Nepal: International Centre for Integrated Mountain Development (ICIMOD). Retrieved from http://www.cabdirect.org/abstracts/20093086376.html;jsessionid=9370528E078D A1E5A4CDCF118C74F81B

Evans, T. P., \& Kelley, H. (2004). Multi-scale analysis of a household level agent-based model of landcover change. Journal of Environmental Management, 72(1-2), 5772. http://doi.org/10.1016/j.jenvman.2004.02.008

Fairhead, J., \& Leach, M. (1996). Misreading the African landscape: society and ecology in a forest-savanna mosaic. New York: Cambridge University Press. Retrieved from https://books.google.com/books?id=CkGl2V-or_UC\&pgis=1

FAO (Food and Agricultural Organization of the United Nations). (1979). Draft report of the Nepal community forestry development project preparatory mission. Washington D.C.

FAO (Food and Agricultural Organization of the United Nations). (2009). Nepal forestry outlook study, Asia-Pacific forestry sector outlook study II (No. II/WP/2009/05). Bangkok. Retrieved from http://www.fao.org/docrep/014/am250e/am250e00.pdf

FAO (Food and Agricultural Organization of the United Nations). (2003). Compendium of agricultural-environmental indicators: 1989-91 to 2000 (p. 36). Rome. Retrieved from http://www.fao.org/fileadmin/templates/ess/documents/other_statistics/compendiu m/agr_env_indic.pdf

Fearnside, P. M. (1985). Environmental change and deforestation in the Brazilian Amazon. In J. Hemming (Ed.), Change in the Amazon Basin: man's impact on forests and rivers (pp. 70-89). Manchester: Manchester University Press.

FECOFUN (Federation of Community Forest Users Nepal). (2014). Members. Retrieved October 1, 2014, from http://fecofun.org.np/members.php

Florent, Q., \& Enrico, B. (2015). Combining agent-based modeling and life cycle assessment for the evaluation of mobility policies. Environmental Science \& Technology, 49(3), 1744-1751. http://doi.org/10.1021/es5060868 
Forestry Nepal. (2014). Master Plan for the Forestry Sector 1989. Retrieved January 27, 2015, from http://www.forestrynepal.org/wiki/102

Fox, J. (1993). Forest resources in a Nepali village in 1980 and 1990: the positive influence of population growth. Mountain Research and Development, 13(1), 8998.

Garmestani, A. S. (2014). Sustainability science: accounting for nonlinear dynamics in policy and social-ecological systems. Clean Technologies and Environmental Policy, 16(4), 731-738. http://doi.org/10.1007/s10098-013-0682-7

Gautam, A. P. (2007). Group size, heterogeneity and collective action outcomes: evidence from community forestry in Nepal. International Journal of Sustainable Development \& World Ecology, 14(6), 574-583. http://doi.org/10.1080/13504500709469756

Gautam, A. P. (2009). Equity and livelihoods in Nepal's community forestry. International Journal of Social Forestry, 2(2), 101-122.

Gautam, A. P., \& Shivakoti, G. P. (2005). Conditions for successful local collective action in forestry: some evidence from the Hills of Nepal. Society \& Natural Resources, 18(2), 153-171. http://doi.org/10.1080/08941920590894534

Gautam, A. P., Shivakoti, G. P., \& Webb, E. L. (2004). A review of forest policies, institutions, and changes in the resource condition in Nepal. International Forestry Review, 6(2), 136-148. http://doi.org/10.1505/ifor.6.2.136.38397

Gilani, H., Shrestha, H. L., Murthy, M. S. R., Phuntso, P., Pradhan, S., Bajracharya, B., \& Shrestha, B. (2015). Decadal land cover change dynamics in Bhutan. Journal of Environmental Management, 148, 91-100. http://doi.org/10.1016/j.jenvman.2014.02.014

GoN (Government of Nepal). (2011). National population and housing census. Kathmandu.

GoN (Government of Nepal). (2014). Review of implementation of the Master Plan for the Forestry Sector: achievements and lessons. Kathmandu.

Graciani Rodrigues, C. C., Espíndola, A. L., \& Penna, T. J. P. (2015). An agent-based computational model for tuberculosis spreading on age-structured populations. Physica A: Statistical Mechanics and Its Applications, 428, 52-59. http://doi.org/10.1016/j.physa.2015.02.027

Grimm, V., Berger, U., DeAngelis, D. L., Polhill, G. J., Giske, J., \& Railsback, S. F. (2010). The ODD protocol: A review and first update. Ecological Modelling, 221(23), 2760-2768. http://doi.org/10.1016/j.ecolmodel.2010.08.019

Grimm, V., \& Railsback, S. F. (2006). Agent-based models in ecology: patterns and alternative theories of adaptive behaviour. In F. C. Billari, T. Fent, A. Prskawetz, \& J. Scheffran (Eds.), Agent-Based Computational Modelling (pp. 139-152). Heidelberg: Physica-Verlag HD. http://doi.org/10.1007/3-7908-1721-X 
Gurung, A., Bista, R., Karki, R., Shrestha, S., Uprety, D., \& Oh, S.-E. (2012).

Community-based forest management and its role in improving forest conditions in Nepal. Small-Scale Forestry, 12(3), 377-388. http://doi.org/10.1007/s11842012-9217-z

Guthman, J. (1997). Representing crisis: the theory of Himalayan environmental degradation and the project of development in post-Rana Nepal. Development and Change, 28, 45-69.

Hansen, M. C., Potapov, P. V, Moore, R., Hancher, M., Turubanova, S. A., Tyukavina, A., ... Townshend, J. R. G. (2013). High-resolution global maps of 21st-century forest cover change. Science (New York, N.Y.), 342(6160), 850-3.

Hawkins, E., \& Sutton, R. (2011). The potential to narrow uncertainty in projections of regional precipitation change. Climate Dynamics, 37(1), 407-418.

http://doi.org/10.1007/s00382-010-0810-6

Hayes, T., \& Ostrom, E. (2005). Conserving the world's forests: are protected areas the only way. Indiana Law Review, 38(3), 595.

Heinen, J. T., \& Mehta, J. N. (2000). Emerging issues in legal and procedural aspects of buffer zone management with case studies from Nepal. The Journal of Environment \& Development, 9(1), 45-67. http://doi.org/10.1177/107049650000900103

Henderson-Sellers, A., \& Gornitz, V. (1984). Possible climatic impacts of land cover transformations, with particular emphasis on tropical deforestation. Climatic Change, 6(3), 231-257.

HMGN (His Majesty’s Government of Nepal). (1989). Historic aerial photographs. Kathmandu: Department of Forest Research and Survey, Ministry of Forests and Soil Conservation.

HMGN (His Majesty’s Government of Nepal). (1991). National population and housing census. Kathmandu.

HMGN (His Majesty’s Government of Nepal). (1993). Forest Act 1993. Kathmandu.

HMGN (His Majesty’s Government of Nepal). (1995). Forest Regulations 1995. Kathmandu.

HMGN (His Majesty’s Government of Nepal). (2001). National population and housing census. Kathmandu.

HMGN (His Majesty’s Government of Nepal). (2002). Nepal Biodiversity Strategy. Kathmandu.

HMGN (His Majesty’s Government of Nepal), ADB (Asian Development Bank), \& FINNIDA (Finnish International Development Agency). (1988). Master Plan for the Forestry Sector Nepal: main report. Kathmandu.

Holland, J. H. (1992). Complex adaptive systems. Daedalus, 121(1), 17-30. 
Holland, J. H. (1995). Hidden order: how adaptation builds complexity. Cambridge: Perseus Books.

Hu, Y., Maskey, S., \& Uhlenbrook, S. (2013). Downscaling daily precipitation over the Yellow River source region in China: a comparison of three statistical downscaling methods. Theoretical and Applied Climatology, 112(3-4), 447-460. http://doi.org/10.1007/s00704-012-0745-4

INSE (International Network for Sustainable Energy). (2005). National energy situation survey report Nepal- focus on renewable energy \& poverty reduction.

Kathmandu. Retrieved from www.inforse.org/asia/word_docs/Nepal-sust-energypoverty.doc

IPCC (Intergovernmental Panel on Climate Change). (2007a). Climate change 2007: the physical science basis. Contribution of working group I to the fourth assessment report of the Intergovernmental Panel on Climate Change. Cambridge. Retrieved from http://www.ipcc.ch/pdf/assessment-report/ar4/wg1/ar4_wg1_full_report.pdf

IPCC (Intergovernmental Panel on Climate Change). (2007b). The fourth assessment report: climate change 2007, synthesis report. Cambridge. Retrieved from https://www.ipcc.ch/pdf/assessment-report/ar4/wg2/ar4_wg2_full_report.pdf

Iversen, V., Chhetry, B., Francis, P., Gurung, M., Kafle, G., Pain, A., \& Seeley, J. (2006). High value forests, hidden economies and elite capture: evidence from forest user groups in Nepal's Terai. Ecological Economics, 58(1), 93-107. http://doi.org/10.1016/j.ecolecon.2005.05.021

Jackson, W. J., \& Tamrakar, R. M. (1998). Land-use changes in two Middle Hills districts of Nepal. Mountain Research and Development, 18(3), 193-212. http://doi.org/10.2307/3674033

Janmaat, J. A., \& Lapp, S. L. (2014). Nepali village model. CoMSES Computational Model Library. Retrieved from https://www.openabm.org/model/4187/version/1

Johnson, T. (2012). Quantifying land cover changes using Landsat data and ArcGIS image analysis. Retrieved January 27, 2015, from http://igett.delmar.edu/Tjohn.html

Jones, S. (2007). Tigers, trees and Tharu: an analysis of community forestry in the buffer zone of the Royal Chitwan National Park, Nepal. Geoforum, 38(3), 558-575. http://doi.org/10.1016/j.geoforum.2006.10.010

Kandel, P. (2010). Forest resource assessment in Nepal: an assessment of data needs. Kathmandu. Retrieved from http://www.forestrynepal.org/images/publications/Data_needs_final.pdf

Karanth, K. K., \& Nepal, S. K. (2012). Local residents perception of benefits and losses from protected areas in India and Nepal. Environmental Management, 49(2), 37286. http://doi.org/10.1007/s00267-011-9778-1 
Karki, R., \& Gurung, A. (2012). An overview of climate change and its impact on agriculture: a review from least developing country, Nepal. International Journal of Ecosystem, 2(2), 19-24. http://doi.org/10.5923/j.ije.20120202.03

Kaul, H., Cui, Z., \& Ventikos, Y. (2013). A multi-paradigm modeling framework to simulate dynamic reciprocity in a bioreactor. PLOS ONE, 8(3), e59671. http://doi.org/10.1371/journal.pone.0059671

Kaul, H., \& Ventikos, Y. (2013). Investigating biocomplexity through the agent-based paradigm. Briefings in Bioinformatics, 16(1), 137-152. http://doi.org/10.1093/bib/bbt077

KC, B., Stainback, G. A., \& Chhetri, B. B. K. (2014). Community users’ and experts’ perspective on community forestry in Nepal: a SWOT-AHP analysis. Forests, Trees and Livelihoods, 23(4), 217-231. http://doi.org/10.1080/14728028.2014.929982

Khadka, M. (2010). Why does exclusion continue in Nepal's community forestry? Aid, knowledge and power in forest policy process. Saarbrücken: Lambert Academic Publishing.

Khadka, M., Karki, S., Karky, B. S., Kotru, R., \& Darjee, K. B. (2014). Gender equality challenges to the REDD+ initiative in Nepal. Mountain Research and Development, 34(3), 197-207. http://doi.org/10.1659/MRD-JOURNAL-D-1300081.1

Kish, L. (1965). Survey sampling. New York: J. Wiley.

Koschke, L., Fürst, C., Frank, S., \& Makeschin, F. (2012). A multi-criteria approach for an integrated land-cover-based assessment of ecosystem services provision to support landscape planning. Ecological Indicators, 21, 54-66. http://doi.org/10.1016/j.ecolind.2011.12.010

Lambin, E. F., Geist, H. J., \& Lepers, E. (2003). Dynamics of land-use and land-cover change in tropical regions. Annual Review of Environment and Resources, 28, 205-241. http://doi.org/10.1146/annurev.energy.28.050302.105459

Langevin, J., Wen, J., \& Gurian, P. L. (2015). Simulating the human-building interaction: Development and validation of an agent-based model of office occupant behaviors. Building and Environment, 88, 27-45. http://doi.org/10.1016/j.buildenv.2014.11.037

Lempert, R. (2002). Agent-based modeling as organizational and public policy simulators. Proceedings of the National Academy of Sciences of the United States of America, 99 Suppl 3(90003), 7195-7196. http://doi.org/10.1073/pnas.072079399

Levin, S. A. (1998). Ecosystems and the biosphere as complex adaptive systems. Ecosystems, 1(5), 431-436. http://doi.org/10.1007/s100219900037

Levin, S. A. (1999). Fragile dominion: complexity and the commons. New York: Basic Books. 
Levin, S. A. (2003). Complex adaptive systems: exploring the known, the unknown and the unknowable. Bulletin, New Series, of the American Mathematical Society, 40(1), 3-20. http://doi.org/10.1090/S0273-0979-02-00965-5

Levin, S. A., Xepapadeas, T., Crépin, A.-S., Norberg, J., De Zeeuw, A., Folke, C., ... Walker, B. (2013). Social-ecological systems as complex adaptive systems: modeling and policy implications. Environment and Development Economics, 18(2), 111-132. http://doi.org/10.1017/S1355770X12000460

Liu, J., Dietz, T., Carpenter, S. R., Alberti, M., Folke, C., Moran, E., ... Taylor, W. W. (2007). Complexity of coupled human and natural systems. Science (New York, N.Y.), 317(5844), 1513-1516. http://doi.org/10.1126/science.1144004

Lund, J. F., Baral, K., Bhandari, N. S., Chhetri, B. B. K., Larsen, H. O., Nielsen, Ø. J., ... Treue, T. (2014). Who benefits from taxation of forest products in Nepal's community forests? Forest Policy and Economics, 38, 119-125. http://doi.org/10.1016/j.forpol.2013.04.010

Lyon, F. (2000). Trust, networks and norms: the creation of social capital in agricultural economies in Ghana. World Development, 28(4), 663-681. http://doi.org/10.1016/S0305-750X(99)00146-1

Mac Nally, R. (2002). Multiple regression and inference in ecology and conservation biology: further comments on identifying important predictor variables.

Biodiversity and Conservation, 11(8), 1397-1401. http://doi.org/10.1023/A:1016250716679

Mahat, I. (2009). Doing fieldwork in development research: issues in applications of methodologies. In I. Mahat (Ed.), Gender and rural energy technologies in Nepal: planning and policy perspectives (p. 400). Saarbrücken, Germany: VDM Publishing.

Malanson, G. P., Zeng, Y., \& Walsh, S. J. (2006). Complexity at advancing ecotones and frontiers. Environment and Planning A, 38(4), 619-632. http://doi.org/10.1068/a37340

Malla, G. (2008). Climate change and its impact on Nepalese agriculture. Journal of Agriculture and Environment, 9, 62-71. http://doi.org/10.3126/aej.v9i0.2119

Malla, Y. B., Neupane, H. R., \& Branney, P. J. (2003). Why aren’t poor people benefiting more from community forestry? Journal of Forest and Livelihood, 3(1), 78-92.

Marin, A. (2010). Riders under storms: contributions of nomadic herders' observations to analysing climate change in Mongolia. Global Environmental Change, 20(1), 162-176. http://doi.org/10.1016/j.gloenvcha.2009.10.004

Maskey, S., Uhlenbrook, S., \& Ojha, S. (2011). An analysis of snow cover changes in the Himalayan region using MODIS snow products and in-situ temperature data. Climatic Change, 108(1-2), 391-400. http://doi.org/10.1007/s10584-011-0181-y 
Matthews, R. B., Gilbert, N. G., Roach, A., Polhill, G. J., \& Gotts, N. M. (2007). Agentbased land-use models: a review of applications. Landscape Ecology, 22(10), 1447-1459. http://doi.org/10.1007/s10980-007-9135-1

McDougall, C. L., Leeuwis, C., Bhattarai, T., Maharjan, M. R., \& Jiggins, J. (2013). Engaging women and the poor: adaptive collaborative governance of community forests in Nepal. Agriculture and Human Values, 30(4), 569-585. http://doi.org/10.1007/s10460-013-9434-X

Mehta, J. N., \& Heinen, J. T. (2001). Does community-based conservation shape favorable attitudes among locals? An empirical study from Nepal. Environmental Management, 28(2), 165-177. http://doi.org/10.1007/s10531-011-9993-3

Mehta, J. N., \& Kellert, S. R. (1998). Local attitudes toward community-based conservation policy and programmes in Nepal: a case study in the Makalu-Barun Conservation Area. Environmental Conservation, 25(4), 320-333. http://doi.org/10.1017/S037689299800040X

Mena, C. F., Walsh, S. J., Frizzelle, B. G., Xiaozheng, Y., \& Malanson, G. P. (2011). Land use change on household farms in the Ecuadorian Amazon: design and implementation of an agent-based model. Applied Geography, 31(1), 210-222. http://doi.org/10.1016/j.apgeog.2010.04.005

Miller, K. D. (2015). Agent-based modeling and organization studies: a critical realist perspective. Organization Studies, 36(2), 175-196. http://doi.org/10.1177/0170840614556921

Molden, D., \& Sharma, E. (2013). ICIMOD’s strategy for delivering high-quality research and achieving impact for sustainable mountain development. Mountain Research and Development, 33(2), 179-183. http://doi.org/10.1659/MRDJOURNAL-D-13-00018.1

Moser, C. A., \& Kalton, G. (1971). Survey methods in social investigation (2nd ed.). London: Heinemann Educational.

Mudimu, E., \& Engelbrecht, G. N. (2015). Agent-based model for social and sexual partnerships formation. Adaptive Behavior, 23(1), 34-49. http://doi.org/10.1177/1059712314547709

Nagendra, H. (2007). Drivers of reforestation in human-dominated forests. Proceedings of the National Academy of Sciences of the United States of America, 104(39), 15218-23. http://doi.org/10.1073/pnas.0702319104

Nagendra, H., Karmacharya, M., \& Karna, B. (2005). Evaluating forest management in Nepal: views across space and time. Ecology and Society, 10(1), 24.

Nagendra, H., \& Ostrom, E. (2007). Institutions, collective action and effective forest management: learning from studies in Nepal. In J. Pretty, A. S. Ball, T. Benton, J. Guivant, D. R. Lee, D. Orr, ... H. Ward (Eds.), The SAGE handbook of environment and society (pp. 578-590). London: SAGE Publications Ltd. http://doi.org/http://dx.doi.org/10.4135/9781848607873.n39 
Nagendra, H., Pareeth, S., Sharma, B., Schweik, C. M., \& Adhikari, K. R. (2007). Forest fragmentation and regrowth in an institutional mosaic of community, government and private ownership in Nepal. Landscape Ecology, 23(1), 41-54. http://doi.org/10.1007/s10980-007-9162-y

Nagendra, H., Tucker, C., Carlson, L., Southworth, J., Karmacharya, M., \& Karna, B. (2004). Monitoring parks through remote sensing: studies in Nepal and Honduras. Environmental Management, 34(5), 748-60. http://doi.org/10.1007/s00267-0040028-7

NCVST (Nepal Climate Vulnerability Team). (2009). Vulnerability through the eyes of vulnerable: climate change induced uncertainties and Nepal's development predicaments. Boulder; Kathmandu. Retrieved from http://i-s-et.org/resources/major-program-reports/vulnerability-through-the-eyes-ofvulnerable.html

Nelson, T., Coops, N., Wulder, M., Perez, L., Fitterer, J., Powers, R., \& Fontana, F. (2014). Predicting climate change impacts to the Canadian Boreal forest. Diversity, 6(1), 133-157. http://doi.org/10.3390/d6010133

Nepal, S. K., \& Spiteri, A. (2011). Linking livelihoods and conservation: an examination of local residents' perceived linkages between conservation and livelihood benefits around Nepal's Chitwan National Park. Environmental Management, 47(5), 727-738. http://doi.org/10.1007/s00267-011-9631-6

Nepal, S. K., \& Weber, K. E. (1995). A buffer zone for biodiversity conservation: viability of the concept in Nepal's Royal Chitwan National Park. Environmental Conservation, 21(4), 333-341. http://doi.org/10.1017/S0376892900033646

Niraula, R. R., Gilani, H., Pokharel, B. K., \& Qamer, F. M. (2013). Measuring impacts of community forestry program through repeat photography and satellite remote sensing in the Dolakha district of Nepal. Journal of Environmental Management, 126, 20-9. http://doi.org/10.1016/j.jenvman.2013.04.006

Norgaard, R. B. (1994). Development betrayed: the end of progress and a coevolutionary revisioning of the future. London: Routledge.

Ojha, H. R., Ghimire, S., Pain, A., Nightingale, A., Khatri, D. B., \& Dhungana, H. (2015). Policy without politics: technocratic control of climate change adaptation policy making in Nepal. Climate Policy, 1-19. http://doi.org/10.1080/14693062.2014.1003775

Olesen, J. E., \& Bindi, M. (2002). Consequences of climate change for European agricultural productivity, land use and policy. European Journal of Agronomy, 16(4), 239-262. http://doi.org/10.1016/S1161-0301(02)00004-7

Oppenheim, A. N. (1992). Questionnaire design, interviewing, and attitude measurement. London: Pinter Publishers.

Ostrom, E. (1990). Governing the commons: the evolution of institutions for collective action. New York: Cambridge University Press. 
Ostrom, E. (2010). Beyond markets and states: polycentric governance of complex economic systems. The American Economic Review, 100(3), 641-672. http://doi.org/10.1257/aer.100.3.641

Ostrom, E., Schroeder, L. D., \& Wynne, S. G. (1993). Institutional incentives and sustainable development: infrastructure policies in perspective. Boulder: Westview Press.

Palazzoli, I., Maskey, S., Uhlenbrook, S., Nana, E., \& Bocchiola, D. (2015). Impact of prospective climate change on water resources and crop yields in the Indrawati basin, Nepal. Agricultural Systems, 133, 143-157. http://doi.org/10.1016/j.agsy.2014.10.016

Pandit, R., \& Bevilacqua, E. (2011a). Forest users and environmental impacts of community forestry in the hills of Nepal. Forest Policy and Economics, 13(5), 345-352. http://doi.org/10.1016/j.forpol.2011.03.009

Pandit, R., \& Bevilacqua, E. (2011b). Social heterogeneity and community forestry processes: reflections from forest users of Dhading district, Nepal. Small-Scale Forestry, 10(1), 97-113. http://doi.org/10.1007/s11842-010-9136-9

Panta, M., Kim, K., \& Joshi, C. (2008). Temporal mapping of deforestation and forest degradation in Nepal: Applications to forest conservation. Forest Ecology and Management, 256(9), 1587-1595. http://doi.org/10.1016/j.foreco.2008.07.023

Parker, D. C., Manson, S. M., \& Berger, T. (2001). Potential strengths and appropriate roles for ABM/LUCC. In D. C. Parker, T. Berger, \& S. M. Manson (Eds.), Meeting the challenge of complexity: proceedings of a special workshop on landuse/land-cover change (pp. 17-24). Irvine: Center for Spatially Integrated Social Science, University of California at Santa Barbara. Retrieved from http://www.csiss.org/events/other/agent-based/additional/proceedings.pdf

Parry, M. L., Rosenzweig, C., Iglesias, A., Livermore, M., \& Fischer, G. (2004). Effects of climate change on global food production under SRES emissions and socioeconomic scenarios. Global Environmental Change, 14(1), 53-67. http://doi.org/10.1016/j.gloenvcha.2003.10.008

Pérez, I., \& Janssen, M. A. (2015). The effect of spatial heterogeneity and mobility on the performance of social-ecological systems. Ecological Modelling, 296, 1-11. http://doi.org/10.1016/j.ecolmodel.2014.10.014

Pokharel, R. K., Tiwari, K. R., \& Rayamajhi, S. (2012). Nepal's community forestry: need of better governance. In C. A. Okia (Ed.), Global perspectives on sustainable forest management (pp. 43-58). InTech. http://doi.org/10.5772/33439

Poteete, A., \& Ostrom, E. (2004). An institutional approach to the study of forest resources. In J. Poulsen (Ed.), Human impacts on tropical forest biodiversity and genetic resources. New York: Oxford University Press.

Poudel, M., Thwaites, R., Race, D., \& Dahal, R. G. (2014). REDD+ and community forestry: implications for local communities and forest management- a case study 
from Nepal. International Forestry Review, 16(1), 39-54.

http://doi.org/10.1505/146554814811031251

Pravat, P. S. (2006). A history of forest politics in the Terai, Nepal: a case of equity or ecology? In ECPR Summer School on Environmental Politics. Staffordshire: Keele University School on Environmental Politics.

Purnomo, H., Mendoza, G. A., Prabhu, R., \& Yasmi, Y. (2005). Developing multistakeholder forest management scenarios: a multi-agent system simulation approach applied in Indonesia. Forest Policy and Economics, 7(4), 475-491. http://doi.org/10.1016/j.forpol.2003.08.004

R Core Team. (2014). R: a language and environment for statistical computing. Vienna: R Foundation for Statistical Computing. Retrieved from http://www.r-project.org/

Rahmandad, H., \& Sterman, J. (2008). Heterogeneity and network structure in the dynamics of diffusion: comparing agent-based and differential equation models. Management Science, 54(5), 998-1014. http://doi.org/10.1287/mnsc.1070.0787

Rai, M. (2007). Climate change and agriculture: a Nepalese case. Journal of Agriculture and Environment, 8, 92-95. http://doi.org/10.3126/aej.v8i0.732

Railsback, S. F., \& Grimm, V. (2012). Agent-based and individual-based modeling: a practical introduction. Princeton: Princeton University Press.

REDD (United Nations Collaborative Initiative on Reducing Emissions from Deforestation and Forest Degradation). (2014). REDD in Nepal. Retrieved October 1, 2014, from http://theredddesk.org/countries/nepal

Richards, J. F., \& Tucker, R. P. (1988). World deforestation in the twentieth century. Durham, NC: Duke University Press.

Rindfuss, R. R., Entwisle, B., Walsh, S. J., An, L., Badenoch, N., Brown, D. G., ... Verburg, P. H. (2008). Land use change: complexity and comparisons. Journal of Land Use Science, 3(1), 1-10. http://doi.org/10.1080/17474230802047955

Riolo, R. L., Cohen, M. D., \& Axelrod, R. M. (2001). Evolution of cooperation without reciprocity. Nature, 414(6862), 441-443. http://doi.org/10.1038/35106555

Rolfe, J., Bennett, J., \& Louviere, J. (2000). Choice modelling and its potential application to tropical rainforest preservation. Ecological Economics, 35(2), 289302. http://doi.org/10.1016/S0921-8009(00)00201-9

Sah, J. P., \& Heinen, J. T. (2002). Wetland resource use and conservation attitudes among indigenous and migrant peoples in Ghodaghodi Lake area, Nepal. Environmental Conservation, 28(04), 345-356. http://doi.org/10.1017/S0376892901000376

Salle, I. L. (2015). Modeling expectations in agent-based models — an application to central bank's communication and monetary policy. Economic Modelling, 46, 130-141. http://doi.org/10.1016/j.econmod.2014.12.040 
Saqalli, M., Bielders, C. L., Gerard, B., \& Defourny, P. (2010). Simulating rural environmentally and socio-economically constrained multi-activity and multidecision societies in a low-data context: a challenge through empirical agentbased modeling. Journal of Artificial Societies and Social Simulation, 13(2), 1.

Sauvageau, G., \& Frayret, J.-M. (2015). Waste paper procurement optimization: an agent-based simulation approach. European Journal of Operational Research, 242(3), 987-998. http://doi.org/10.1016/j.ejor.2014.10.035

Schreier, H., Brown, S., Schmidt, M., Shah, P., Shrestha, B., Nakarmi, G., ... Wymann, S. (1994). Gaining forests but losing ground: a GIS evaluation in a Himalayan watershed. Environmental Management, 18(1), 139-150. http://doi.org/10.1007/BF02393756

Schweik, C. M., Nagendra, H., \& Sinha, D. R. (2003). Using satellite imagery to locate innovative forest management practices in Nepal. AMBIO, 32(4), 312-319. http://doi.org/10.1579/0044-7447-32.4.312

Sharma, P., Guha-Khasnobis, B., \& Raj Khanal, D. (2014). Nepal human development report 2014. (G. Luchsinger, Ed.). Kathmandu: GoN (Government of Nepal) \& UNDP (United Nations Development Programme).

Shivakoti, G. P., \& Ostrom, E. (2002). Improving irrigation governance and management in Nepal. Oakland: ICS Press.

Shivakoti, G. P., \& Ostrom, E. (2008). Facilitating decentralized policies for sustainable governance and management of forest resources in Asia. In E. L. Webb \& G. P. Shivakoti (Eds.), Decentralization, forest and rural communities: policy outcomes in South and Southeast Asia (pp. 292-310). New Delhi: SAGE Publications.

Shrestha, K. K., \& McManus, P. (2007). The embeddedness of collective action in Nepalese community forestry. Small-Scale Forestry, 6(3), 273-290. http://doi.org/10.1007/s11842-007-9020-4

Singh, S. P., Bassignana-Khadka, I., Karky, B. S., \& Sharma, E. (2011). Climate change in the Hindu Kush-Himalayas: the state of current knowledge. (S. P. Singh, I. Bassignana-Khadka, \& B. Karky, Eds.). Kathmandu: International Centre for Integrated Mountain Development (ICIMOD).

Smajgl, A., \& Barreteau, O. (2013). Empirical agent-based modelling-- challenges and solutions. (A. Smajgl \& O. Barreteau, Eds.). New York; Heidelberg; Dordrecht; London: Springer. http://doi.org/10.1007/978-1-4614-6134-0

Spiteri, A., \& Nepal, S. K. (2008). Distributing conservation incentives in the buffer zone of Chitwan National Park, Nepal. Environmental Conservation, 35(1), 76-86. http://doi.org/10.1017/S0376892908004451

Stevens, S. (1983). Tourism and change in Khumbu (Bachelor's thesis). University of California, Berkeley.

Stevens, S. (1993). Claiming the high ground: Sherpas, subsistence, and environmental change in the Highest Himalaya. Berkeley: University of California Press. 
Stevens, S. (1997). Consultation, co-management, and conflict in Sagarmatha (Mount Everest) National Park, Nepal. In S. Stevens (Ed.), Conservation through cultural survival: indigenous peoples and protected areas (pp. 63-97). Washington D.C.: Island Press.

Stevens, S. (2003). Tourism and deforestation in the Mt Everest region of Nepal. The Geographical Journal, 169(3), 255-277. http://doi.org/10.1111/1475-4959.00089

Stræde, S., \& Treue, T. (2006). Beyond buffer zone protection: a comparative study of park and buffer zone products’ importance to villagers living inside Royal Chitwan National Park and to villagers living in its buffer zone. Journal of Environmental Management, 78(3), 251-67. http://doi.org/10.1016/j.jenvman.2005.03.017

Sudman, S., Sirken, M. G., \& Cowan, C. D. (1988). Sampling rare and elusive populations. Science (New York, N.Y.), 240(4855), 991-996. http://doi.org/10.1126/science.240.4855.991

Tashakkori, A., \& Teddlie, C. (1998). Mixed methodology: combining qualitative and quantitative approaches. Thousand Oaks: Sage Publications, Inc.

Thapa, G. J., Wikramanayake, E., \& Forrest, J. (2013). Climate-change impacts on the biodiversity of the Terai Arc landscape and the Chitwan-Annapurna landscape. Kathmandu. Retrieved from http://awsassets.panda.org/downloads/annex_12_12_report_climate_change_im pacts_on_the_biodiversity_of_tal_and_chal_1.pdf

Thoms, C. A. (2008). Community control of resources and the challenge of improving local livelihoods: a critical examination of community forestry in Nepal. Geoforum, 39(3), 1452-1465. http://doi.org/10.1016/j.geoforum.2008.01.006

Thorne, B. C., Bailey, A. M., DeSimone, D. W., \& Peirce, S. M. (2007). Agent-based modeling of multicell morphogenic processes during development. Birth Defects Research. Part C, Embryo Today: Reviews, 81(4), 344-53. http://doi.org/10.1002/bdrc.20106

Thorne, B. C., Bailey, A. M., \& Peirce, S. M. (2007). Combining experiments with multicell agent-based modeling to study biological tissue patterning. Briefings in Bioinformatics, 8(4), 245-57. http://doi.org/10.1093/bib/bbm024

Turkay, C., Koc, E., \& Balcisoy, S. (2011). Integrating information theory in agent-based crowd simulation behavior models. The Computer Journal, 54(11), 1810-1820. http://doi.org/10.1093/comjnl/bxr014

Uddin, K., Shrestha, H. L., Murthy, M. S. R., Bajracharya, B., Shrestha, B., Gilani, H., ... Dangol, B. (2015). Development of 2010 national land cover database for the Nepal. Journal of Environmental Management, 148, 82-90. http://doi.org/10.1016/j.jenvman.2014.07.047

UNDP (United Nations Development Programme). (2014). Nepal climate change support programme. Retrieved March 10, 2015, from 
http://www.np.undp.org/content/nepal/en/home/operations/projects/environment_ and_energy/nccsp/home.html

UNESCO (United Nations Educational Scientific and Cultural Organization). (2013). Chitwan National Park. Retrieved October 1, 2014, from http://whc.unesco.org/en/list/284

Upadhyay, S. (2012). Community based forest and livelihood management in Nepal. In D. Bollier \& S. Helfrich (Eds.), The wealth of the commons: a world beyond market and state. Amherst: Levellers Press. Retrieved from http://wealthofthecommons.org/essay/community-based-forest-and-livelihoodmanagement-nepal

USGS (United States Geological Survey). (2013). Using the USGS Landsat 8 product. Retrieved June 15, 2014, from http://landsat.usgs.gov/Landsat8_Using_Product.php

Vallino, E. (2014). The tragedy of the park: an agent-based model of endogenous and exogenous institutions for forest management. Ecology and Society, 19(1), 35. http://doi.org/10.5751/ES-06242-190135

Varughese, G. (2000). Population and forest dynamics in the hills of Nepal: institutional remedies by rural communities. In C. C. Gibson, M. A. McKean, \& E. Ostrom (Eds.), People and forests: communities, institutions, and governance (pp. 193227). Cambridge: MIT Press.

Varughese, G., \& Ostrom, E. (2001). The contested role of heterogeneity in collective action: some evidence from community forestry in Nepal. World Development, 29(5), 747-765. http://doi.org/10.1016/S0305-750X(01)00012-2

Veldkamp, A., \& Lambin, E. F. (2001). Predicting land-use change. Agriculture, Ecosystems \& Environment, 85(1), 1-6. http://doi.org/10.1016/S01678809(01)00199-2

Virgo, K. J., \& Subba, K. J. (1994). Land-use change between 1978 and 1990 in Dhankuta District, Koshi Hills, Eastern Nepal. Mountain Research and Development, 14(2), 159-170. http://doi.org/10.2307/3673798

Waldrop, M. M. (1992). Complexity: the emerging science at the edge of order and chaos. New York: Simon \& Schuster.

Walsh, S. J., Messina, J. P., Mena, C. F., Malanson, G. P., \& Page, P. H. (2008). Complexity theory, spatial simulation models, and land use dynamics in the Northern Ecuadorian Amazon. Geoforum, 39(2), 867-878. http://doi.org/10.1016/j.geoforum.2007.02.011

Wandersee, S. M., An, L., López-Carr, D., \& Yang, Y. (2012). Perception and decisions in modeling coupled human and natural systems: a case study from Fanjingshan National Nature Reserve, China. Ecological Modelling, 229, 37-49. http://doi.org/10.1016/j.ecolmodel.2011.08.004 
Waring, T. M., Goff, S., \& Smaldino, P. E. (2015). Evolving the core design principles: the coevolution of institutions and sustainable practices. In Press. Retrieved from https://computationalsocialscience.org/wpcontent/uploads/2013/08/WaringEtAl2013.pdf

Wilensky, U., \& Rand, W. (2007). Making models match: replicating an agent-based model. Journal of Artificial Societies and Social Simulation, 10(4), 2.

Windrum, P., Fagiolo, G., \& Moneta, A. (2007). Empirical validation of agent-based models: Alternatives and prospects. Journal of Artificial Societies and Social Simulation, 10(2), 8.

World Bank. (2013). World Bank indicators - Nepal - land use, trading economics. Retrieved June 15, 2014, from http://www.tradingeconomics.com/nepal/forestarea-percent-of-land-area-wb-data.html

Wunder, M., Suri, S., \& Watts, D. (2013). Empirical agent based models of cooperation in public goods games. In Proceedings of the fourteenth ACM conference on electronic commerce (pp. 891-908). New York: ACM. http://doi.org/10.1145/2482540.2482586

Wurzer, G., Kowarik, K., \& Reschreiter, H. (2015). Agent-based modeling and simulation in archaeology. (G. Wurzer, K. Kowarik, \& H. Reschreiter, Eds.). Cham; Heidelberg; New York; Dordrecht; London: Springer International Publishing. http://doi.org/10.1007/978-3-319-00008-4

Zellner, M. L., Theis, T. L., Karunanithi, A. T., Garmestani, A. S., \& Cabezas, H. (2008). A new framework for urban sustainability assessments: linking complexity, information and policy. Computers, Environment and Urban Systems, 32(6), 474 488. http://doi.org/10.1016/j.compenvurbsys.2008.08.003

Zhang, H., Jin, X., Wang, L., Zhou, Y., \& Shu, B. (2015). Multi-agent based modeling of spatiotemporal dynamical urban growth in developing countries: simulating future scenarios of Lianyungang city, China. Stochastic Environmental Research and Risk Assessment, 29(1), 63-78. http://doi.org/10.1007/s00477-014-0942-z

Zvoleff, A., \& An, L. (2014). The effect of reciprocal connections between demographic decision making and land use on decadal dynamics of population and land-use change. Ecology and Society, 19(2), 122-167. http://doi.org/10.5751/ES-06243190231 


\title{
APPENDIX A: INSTITUTIONAL REVIEW BOARD DECISION LETTER
}

\author{
APPLICATION FOR APPROVAL OF RESEARCH WITH HUMAN SUBJECTS \\ Protection of Human Subjects Review Board \\ 114 Alumni Hall, 581-1498
}

PRINCIPAL INVESTIGATOR: Jared Stapp

EMAIL: stappjared@gmail.com TELEPHONE: (435) 757-1238

CO-INVESTIGATOR(S):

FACULTY SPONSOR (Required if PI is a student): Dr. Rob Lilieholm

TITLE OF PROJECT: Assessing the Likelihood of Buffer Zone Communities around Chitwan National Park, Nepal, to Adopt Conservation-oriented Behaviors

START DATE: May 25, 2014

PI DEPARTMENT: Ecology and Environmental Sciences

MAILING ADDRESS: 223 Nutting Hall

FUNDING AGENCY (if any):

STATUS OF PI:

FACULTY/STAFF/GRADUATE/UNDERGRADUATE Graduate Student

1. If PI is a student, is this research to be performed:

for an honors thesis/senior thesis/capstone?
for a doctoral dissertation?
other (specify)

2. Does this application modify a previously approved project? $\mathrm{N}(\mathrm{Y} / \mathrm{N})$. If yes, please give assigned number (if known) of previously approved project:

3. Is an expedited review requested? $\mathrm{Y}(\mathrm{Y} / \mathrm{N})$.

SIGNATURES: All procedures performed under the project will be conducted by individuals qualified and legally entitied to do so. No deviation from the approved protocol will be undertaken without prior approval of the IRB.

Faculty Sponsors are responsible for oversight of research conducted by their students. By signing this application page, the Faculty Sponsor ensures that the conduct of such research will be in accordance with the University of Maine's Policies and Procedures for the Protection of Human Subjects of Research.

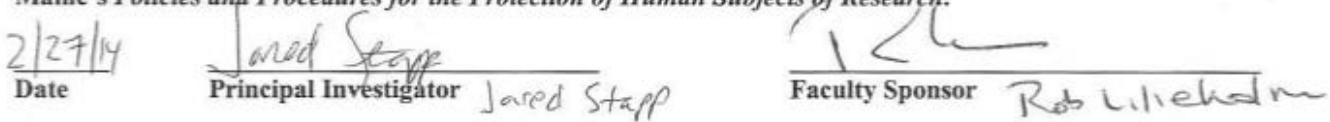

Co-Investigator

Co-Investigator

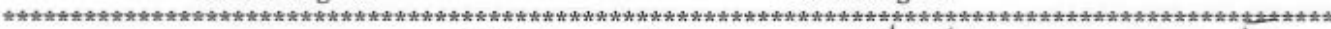
FOR IRB USE ONLY Application \# 20/4 - $22-4 /$ Date received $2 / 27 / 14 \quad$ Review (F/E): 1 ACTION TAKEN:

Expedited Category:

Judged Exempt; category 2 . Modifications required? Y (Y/N) Accepted (date) $3 / 17 / 20 / 4$ Approved as submitted. Date of next review: by Degree of Risk:

Approved pending modifications. Date of next review: by ___. Degree of Risk: Modifications accepted (date):

Not approved. (See attached statement.)

Judged not research with human subjects

Date:

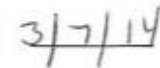

Chair's Signature:

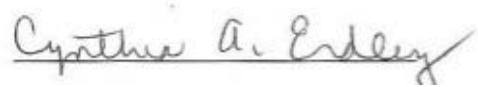

6/12

Figure A.1. University Of Maine Institutional Review Board decision letter (Application \#2014-02-14). 


\section{APPENDIX B: SURVEY CONDUCTED IN NEPAL (IN NEPALI LANGUAGE)}

Survey of Local Views Toward Community Forestry and Conservation Initiatives Jared R. Stapp, University of Maine

Please indicate your level of agreement with the following statements on a scale of 1 (strongly agree) to 5 (strongly disagree).

\begin{tabular}{|c|c|c|c|c|c|c|}
\hline \multirow{2}{*}{\multicolumn{2}{|c|}{$\begin{array}{l}\text { (1) १ मेरो घर दाउराको लागि नजिकैको स्थानिय वनमा निर्भर } \\
\text { छ। }\end{array}$}} & $\begin{array}{l}9 \\
\text { पूर्ण सहमत }\end{array}$ & $\begin{array}{c}\text { २ } \\
\text { सहमत }\end{array}$ & $\begin{array}{l}\text { ३ } \\
\text { तटस्थ }\end{array}$ & $\begin{array}{c}\gamma \\
\text { असहमत }\end{array}$ & $\begin{array}{l}\text { y } \\
\text { पूर्ण असहमत }\end{array}$ \\
\hline & & $\square$ & $\square$ & $\square$ & $\square$ & $\square$ \\
\hline \multicolumn{2}{|c|}{ (2) २ मेरो घर घाँसको लागि स्थानिय वनमा निर्भर छ। } & $\square$ & $\square$ & $\square$ & $\square$ & $\square$ \\
\hline \multicolumn{2}{|c|}{$\begin{array}{l}\text { (3) ₹ मरो समुदायमा वनको अवस्थामा तत्कालिन समयमा } \\
\text { सुधार आएको देखिन्छ। }\end{array}$} & $\square$ & $\square$ & $\square$ & $\square$ & $\square$ \\
\hline \multicolumn{2}{|c|}{ (4) $\checkmark$ म मेरो समुदायमा रहेको वर्तमान अवस्थाप्रति सन्तुष्ट छु } & $\square$ & $\square$ & $\square$ & $\square$ & $\square$ \\
\hline \multicolumn{2}{|c|}{$\begin{array}{l}\text { (5) } 2 \text { म मेरो ठांडको सामुदायिक वन उपभोका संचालन तथा } \\
\text { प्रभावकारितामा सक्रिय रुपले सहभागि छु। }\end{array}$} & $\square$ & $\square$ & $\square$ & $\square$ & $\square$ \\
\hline \multicolumn{2}{|c|}{$\begin{array}{l}\text { (6) ६ सामाजिक सहकार्यले मेरो समुदायको वनको अवस्थामा } \\
\text { सुधार भएको छ। }\end{array}$} & $\square$ & $\square$ & $\square$ & $\square$ & $\square$ \\
\hline \multicolumn{2}{|c|}{$\begin{array}{l}\text { (7) } ง \text { सामुदायिक वन उपभोका प्रयासले मेरो समुदायको } \\
\text { वनको अवस्थामा सुधार भएको छ। }\end{array}$} & $\square$ & $\square$ & $\square$ & $\square$ & $\square$ \\
\hline \multicolumn{2}{|c|}{$\begin{array}{l}\text { (8) } 5 \text { सबै समुदायका सदस्यहरुले सामुदायिक वन व्यवस्थापन } \\
\text { अनुरुपको समान फाइदा पाउनुपर्छ, भन्ने कुरा महत्वपूर्ण छा }\end{array}$} & $\square$ & $\square$ & $\square$ & $\square$ & $\square$ \\
\hline \multicolumn{2}{|c|}{$\begin{array}{l}\text { (9) } 9 \text { मलाइ लाग्छ पुन वृक्षारोपणमा जोड दिने NGO हरुको } \\
\text { सहयोगले हाम्रो समुदायको वनको अवस्थामा सुधार भएको छा। }\end{array}$} & $\square$ & $\square$ & $\square$ & $\square$ & $\square$ \\
\hline \multicolumn{2}{|c|}{$\begin{array}{l}\text { (10) १० म NGO हरु संग काम गनें र सहयोग पाउने आशा } \\
\text { राख्दछ्छ जस्ले मेरो सामुदायिक वनको अवस्थामा सुधार गछ्छ। }\end{array}$} & $\square$ & $\square$ & $\square$ & $\square$ & $\square$ \\
\hline \multicolumn{2}{|c|}{ (11) १९ म तत्कालिन वन नियमहरु प्रति सन्तुष्ट छु। } & $\square$ & $\square$ & $\square$ & $\square$ & $\square$ \\
\hline \multicolumn{2}{|c|}{ (12) १२ म जिल्ला वन कार्यालयका कर्मचारीप्रति सन्तुष्ट छु। } & $\square$ & $\square$ & $\square$ & $\square$ & $\square$ \\
\hline \multicolumn{2}{|c|}{$\begin{array}{l}\text { (13) १३ नेपालको तत्कालिन राजनैतिक वातावरणले दिगो वन } \\
\text { व्यवस्थापनमा प्रतत्साहन गरेको छ। }\end{array}$} & $\square$ & $\square$ & $\square$ & $\square$ & $\square$ \\
\hline \multicolumn{2}{|c|}{$\begin{array}{l}\text { (14) १४ वनको दिगोपनाको लागि बचाउन राम्रो र सुधारिएका } \\
\text { चुल्लोको महत्वपूर्ण भूमिका छ। }\end{array}$} & & & & & \\
\hline \multicolumn{2}{|c|}{$\begin{array}{l}\text { (15) १४ वनको दिगोपनाको लागि मेरो समुदायमा } \\
\text { गोबरग्यासको महत्वपुर्ण भूमिका छ। }\end{array}$} & $\square$ & $\square$ & $\square$ & $\square$ & $\square$ \\
\hline \multicolumn{7}{|c|}{$\begin{array}{l}\text { (16) १६ यदि कुनै पनि आर्थिक कारण छैन भने म अपनाउन } \\
\text { सक्छु। }\end{array}$} \\
\hline (a) सुधारिएको चुल्हो & $\begin{array}{l}\text { पहिल्यै प्रयोग } \\
\text { गरिसकेको } \square\end{array}$ & $\square$ & $\square$ & $\square$ & $\square$ & $\square$ \\
\hline (b) घरेलु बायोग्यास & $\begin{array}{l}\text { पहिल्यै प्रयोग } \\
\text { गरिसकेको } \square\end{array}$ & $\square$ & $\square$ & $\square$ & $\square$ & $\square$ \\
\hline
\end{tabular}

Figure B.1. Survey in Nepali (side 1). 
(17) १७ तपाइको वनको सहयोगको लागि कुन सरकारी नियम परिवर्तन गरिनुपर्दछ जस्तो लाग्छ?

(18) १६ तपाइ बसेको ठाउमा सामुदायिक साभंदारी माफंत सामुदायिक वन व्यवस्थापन गर्दा आइपनें कठिनाईं हरु के के हुन्?

\begin{tabular}{|c|c|c|c|c|c|}
\hline (19) लिड & $\begin{array}{l}\text { पुरुष } \\
\square\end{array}$ & $\begin{array}{l}\text { महिला } \\
\text { व }\end{array}$ & & & \\
\hline (20) सामुदायिक वनको सदस्य & छ & $\begin{array}{l}\text { छैन } \\
\square\end{array}$ & & & \\
\hline (21) शिक्षा & $\begin{array}{c}\text { निराक्षर } \\
\square\end{array}$ & $\begin{array}{c}\text { प्ररामिक } \\
\square\end{array}$ & $\begin{array}{c}\text { निम्नमाधायमिक } \\
\square\end{array}$ & $\begin{array}{c}\text { माध्यमिक } \\
\square\end{array}$ & $\begin{array}{c}\text { उच माध्यमिक } \\
\square\end{array}$ \\
\hline (22) स्थानिय कि अन्य क्षेत्र बाट आउनु भएको & $\begin{array}{l}\text { कृपाय क्षेत्र } \\
\text { लेखनुहोस }\end{array}$ & & & & \\
\hline (23) जात & $\begin{array}{l}\text { कृपाय जात } \\
\text { लेखनुहोस }\end{array}$ & & & & \\
\hline (24) थर & $\begin{array}{l}\text { कृपाय थर } \\
\text { लेखनुहोस }\end{array}$ & & & & \\
\hline (25) उमेर & $\begin{array}{l}\text { कुपाय उमेर } \\
\text { लेखनुहोस }\end{array}$ & & & & \\
\hline (26) पेशा & $\begin{array}{l}\text { कृपाय पेशा } \\
\text { लेखनुहोस }\end{array}$ & & & & \\
\hline (27) परिवार सदस्य संख्या & $\begin{array}{l}\text { कृपाय संख्या } \\
\text { लेखनुहोस }\end{array}$ & पुरुष & महिला & & \\
\hline (28) जगगा हेक्टर & $\begin{array}{l}\text { कृपाय हेक्टर } \\
\text { लेखनुहोस }\end{array}$ & & & & \\
\hline (29) वस्तु & भैसि & बाखा & गाई & , सुगुर & ----- \\
\hline (30) आफनु पेशाले घरको खर्च धान्न सक्नु भएको छ? & $\begin{array}{l}\text { छैन } \\
\square\end{array}$ & $\begin{array}{l}\text { कहिलकाहि } \\
\square\end{array}$ & छ & & \\
\hline
\end{tabular}

\begin{tabular}{|l|l|}
\hline Date and time: & \\
\hline Surveyors: & \\
\hline VDC: & \\
\hline Village: & \\
\hline GPS Coord. & \\
\hline
\end{tabular}

Figure B.2. Survey in Nepali (side 2). 


\section{APPENDIX C: SURVEY CONDUCTED IN NEPAL (IN ENGLISH)}

Please indicate your level of agreement with the following statements on a scale of 1 (strongly agree) to 5 (strongly disagree).

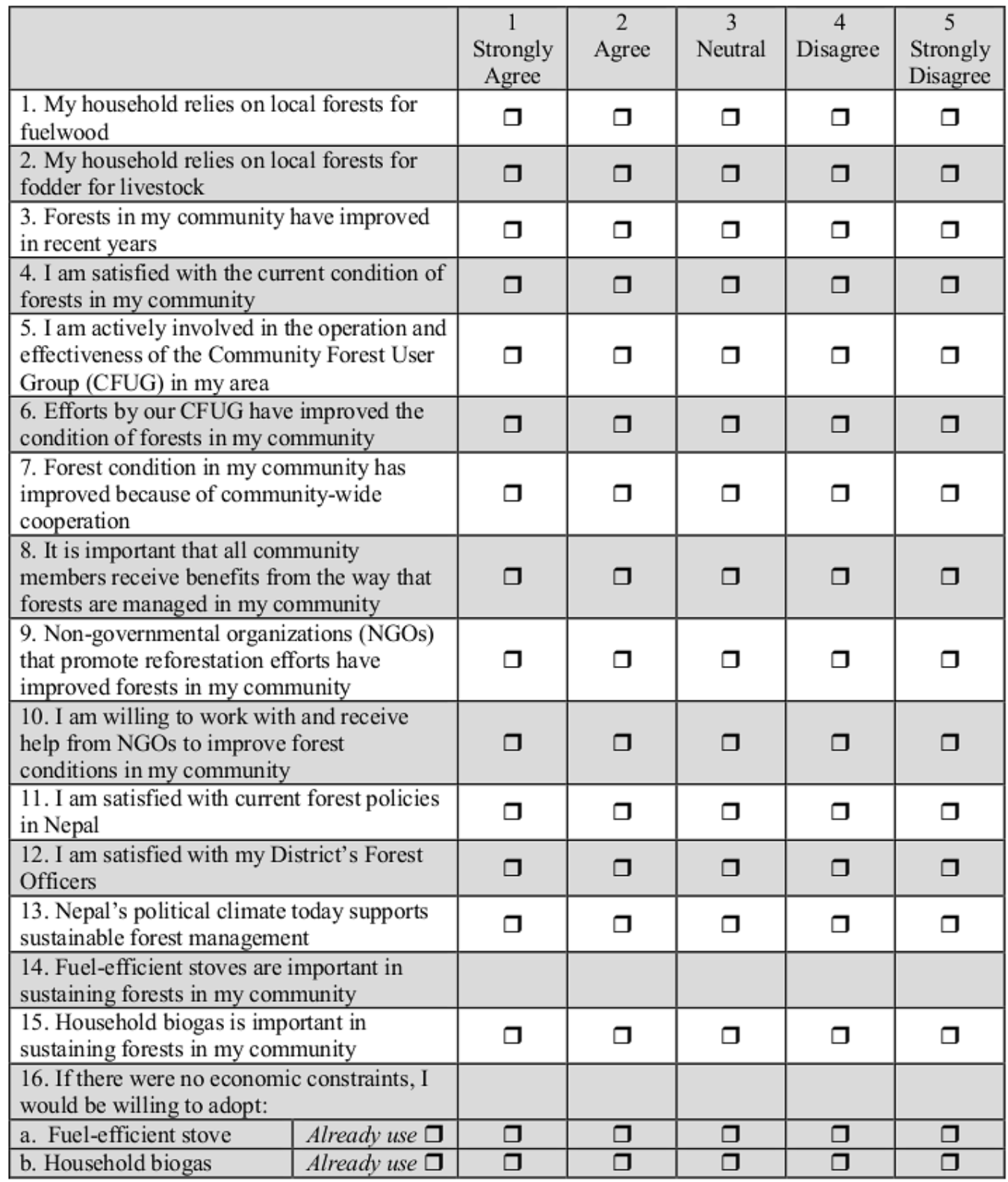

Figure C.1. Survey in English (side 1). 
17. What governmental/policy changes do you think need to be made to support forests in your community?

18. What barriers limit community-wide cooperation in managing community forests where you live?

\begin{tabular}{|c|c|c|c|c|c|}
\hline 19. Gender & $\begin{array}{c}\text { Male } \\
\square\end{array}$ & $\begin{array}{c}\text { Female } \\
\square\end{array}$ & & & \\
\hline 20. I am a member of a CFUG & $\begin{array}{c}\text { Yes } \\
\square\end{array}$ & $\begin{array}{c}\text { No } \\
\square\end{array}$ & & & \\
\hline 21. Education & $\begin{array}{l}\text { None } \\
\square\end{array}$ & $\begin{array}{l}\text { Primary } \\
\square\end{array}$ & $\begin{array}{c}\text { Lower } \\
\text { Secondary } \\
\square\end{array}$ & $\begin{array}{c}\text { Secondary } \\
\square\end{array}$ & $\begin{array}{l}\text { Unive } \\
\text { rsity } \\
\square\end{array}$ \\
\hline 22. Region of origin & Please Write: & & & & \\
\hline 23. Ethnicity & Please Write: & & & & \\
\hline 24. Caste & Please Write: & & & & \\
\hline 25. Age & Please Write: & & & & \\
\hline 26. Occupation & Please Write: & & & & \\
\hline $\begin{array}{l}\text { 27. Number of persons in your } \\
\text { household }\end{array}$ & Please Write: & & & & \\
\hline $\begin{array}{l}28 . \text { How many hectares of land do } \\
\text { you own? }\end{array}$ & Please Write: & & & & \\
\hline $\begin{array}{l}\text { 29. How many of each type of } \\
\text { livestock do you own? }\end{array}$ & Buffaloes & Goats & Cattle & Pigs & \\
\hline $\begin{array}{l}30 . \text { With your occupation, are you } \\
\text { able to meet your household's } \\
\text { everyday needs? }\end{array}$ & $\begin{array}{c}\text { No } \\
\square\end{array}$ & $\begin{array}{c}\text { Sometimes } \\
\square\end{array}$ & $\begin{array}{c}\text { Yes } \\
\square\end{array}$ & & \\
\hline
\end{tabular}

\begin{tabular}{|l|l|}
\hline $\begin{array}{l}\text { Date and } \\
\text { time: }\end{array}$ & \\
\hline Surveyors: & \\
\hline VDC: & \\
\hline Village: & \\
\hline GPS Coord. & \\
\hline
\end{tabular}

Figure C.2. Survey in English (side 2). 


\section{APPENDIX D: FULL, DOCUMENTED AGENT-BASED MODEL CODE}

Table D.1. Full, documented code for agent-based model presented in Chapter 3.

\section{Global, Spatial, and Village Variables; Extensions; Breeds}

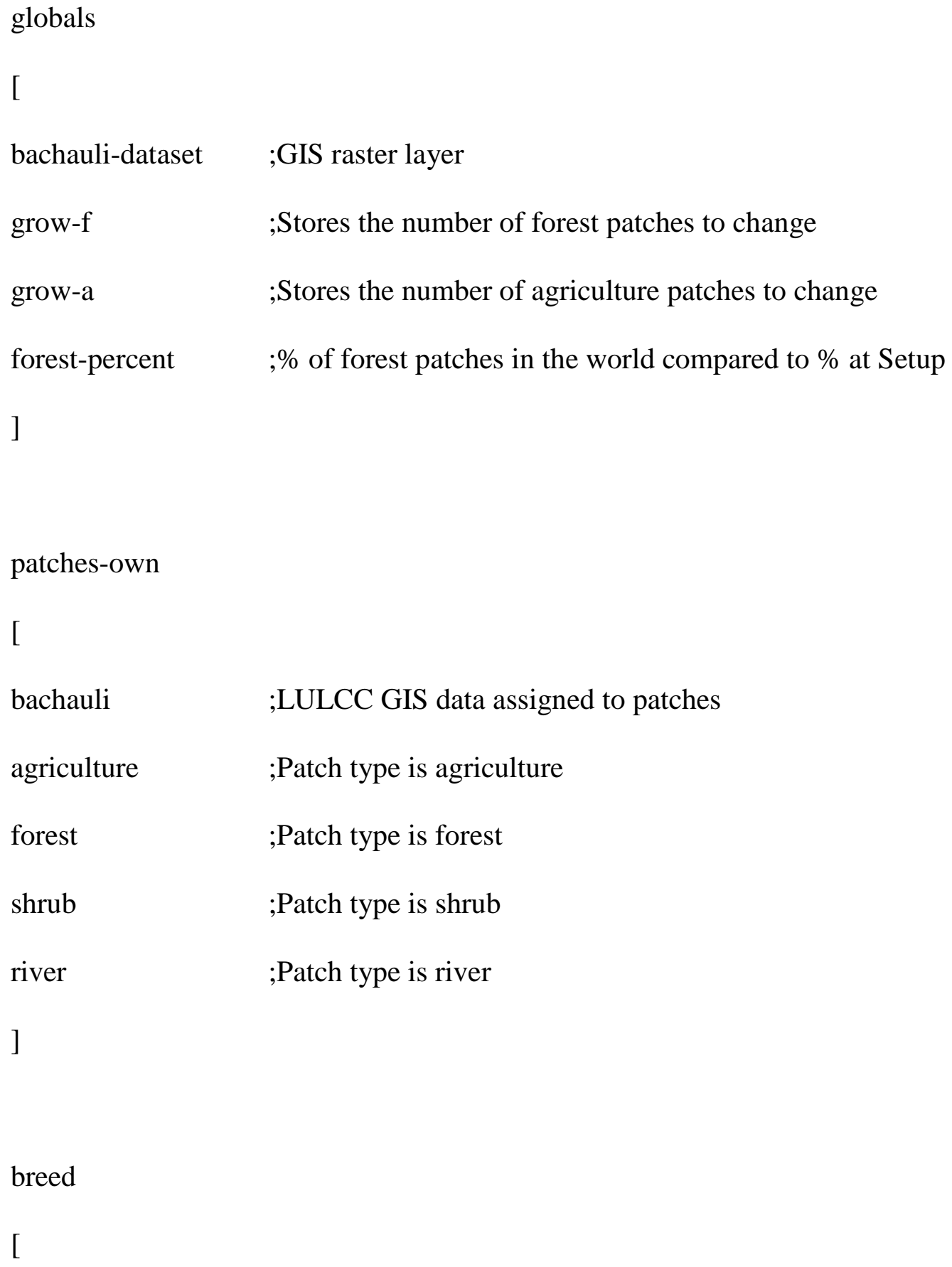


$\begin{array}{ll}\text { villages } & \text {;All five villages } \\ \text { village } & \text {;Each individual village }\end{array}$

villages-own

[

forestneed

cacf

policy

name

population

pop-original

village-score

support-f?

pop-patches

]

extensions

[ gis ]

$\underline{\text { Setup Procedures }}$

to setup

clear-all
;Household need for forests and perception of forest trends

;Willingness to support collective action and community forestry

;Supportive of forest-related institutions and policies in place

;Name of each village to be displayed as a label

;Current population of each village

;Original population of each village

;Combined, mean score from all three input attitude variables

;Describes whether or not the village supports forests

;Number of patches a village is able to convert to either forest or ag.

NetLogo GIS Extension for using GIS data in the model 


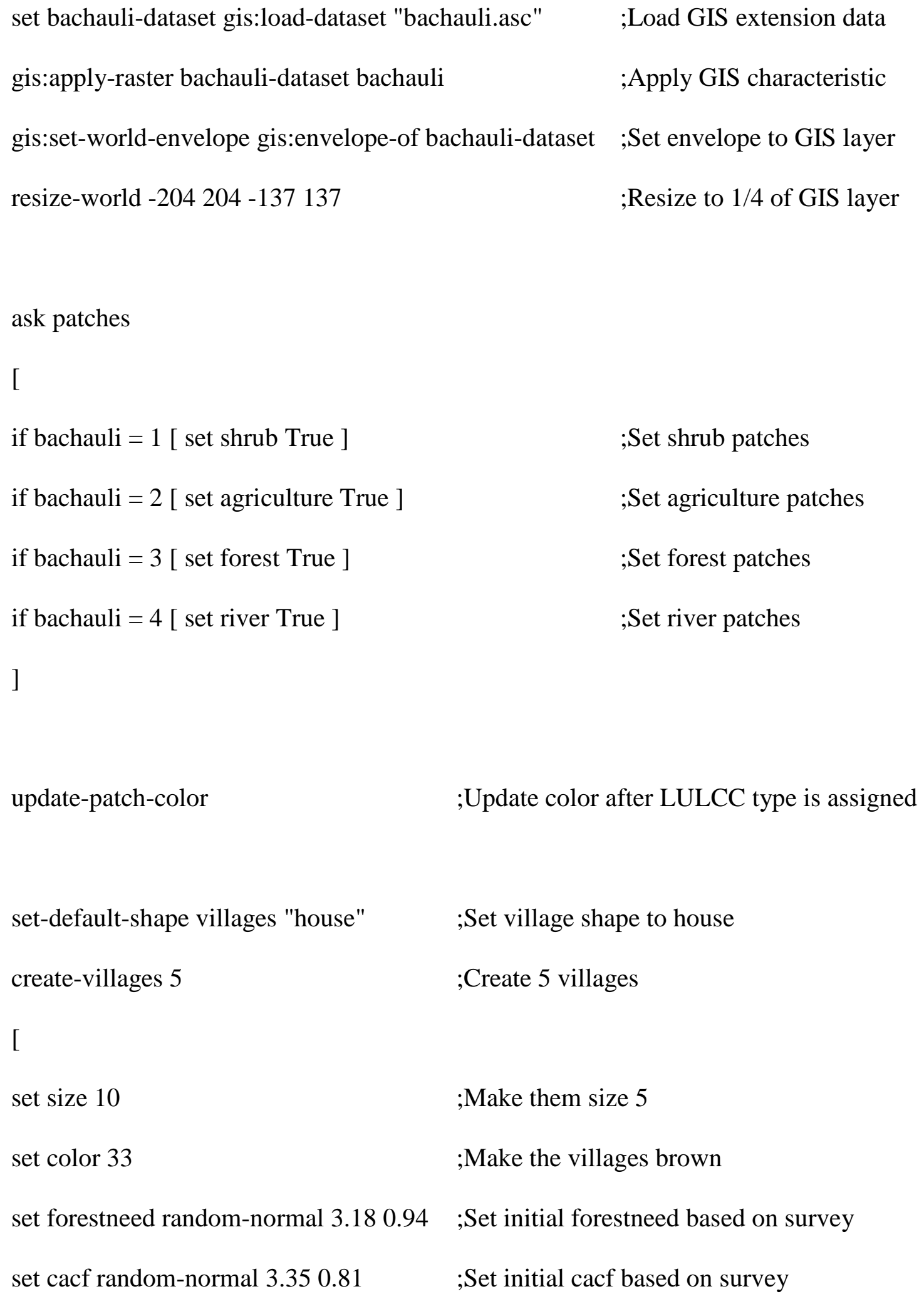




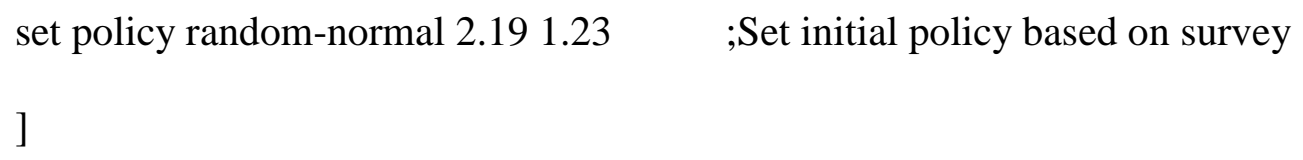


set name "Jankauli"

setxy -29 22

set population 1510

set pop-original 1510

set pop-patches ( round ( population / 1000 ) )
;Set/name Village 2 as Jankauli

;Set Jankauli location

;Set Jankauli current population

;Set Jankauli original population

;Set Jankauli pop-patches as pop /1,000
]

ask village 3

[

set name "Jhuwani"

setxy 7981

set population 2560

set pop-original 2560

set pop-patches ( round ( population / 1000 ) )
;Set/name Village 3 as Jhuwani

;Set Jhuwani location

;Set Jhuwani current population

;Set Jhuwani original population

;Set Jhuwani pop-patches as pop /1,000

ask village 4

[

set name "Tarauli"

;Set/name Village 3 as Tarauli

setxy 11383

;Set Tarauli location

set population 600

;Set Tarauli current population

set pop-original 600

;Set Tarauli original population

set pop-patches ( round ( population / 1000 ) ) ;Set Tarauli pop-patches as pop /1,000 
ask villages

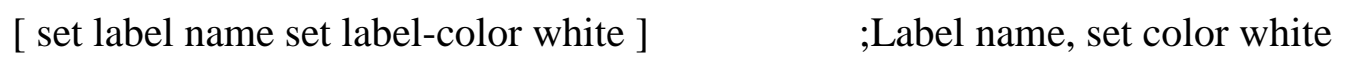

if gov-policy = True $\quad$;If gov-policy is True:

[

ask villages

[ if random-float $1>.5 \quad$;There is a $50 \%$ probability of:

[ set policy ( policy * $1+$ random-float 0.05 ) ] ] ;Increase policy by \# between 0 - 5\%

]

if equal-rights-policy = True ;If equal-rights-policy is True:

[

ask villages

[ if random-float $1>.5 \quad$;There is a $50 \%$ probability of:

[ set $\operatorname{cacf}(\operatorname{cacf} * 1+$ random-float 0.05$)$ ] ] $\quad$;Increase cacf by \# between 0 - 5\%

]

ask villages

[

set village-score ; Set base village score by:

$(($ ( forestneed + cacf + policy $) / 3$ ) / 5 ) $\quad$;Mean of 3 scores, /5

] 
set mimic-neighbors mimic-neighbors

set forest-percent precision (((count patches with

[ forest $=$ True ] ) $/ 44777$ ) $* 100$ ) 2

reset-ticks

end
;Set to value slider is set to

;Set base value for forest-percent as:

;\% of forest relative to amount at Setup

;Reset ticks

\section{Go Procedures}

to go

if ticks $=300[$ stop $]$

;After 300 months (25 years) have passed, stop the model

calculate-village-score

;Change 3 scores, calculate mean from 3 input variables

calculate-support-for-forests

;Determine whether or not each village supports forests

calculate-patches-conversions

;Calculate \# patches will be converted to ag. \& forest

convert-patches

;Convert randomly selected patches to forest and ag.

grow-population

; Increase population by value of population-growth-rate

update-patch-color

;Update patch colors after patch conversions

tick

;Add one tick (equals one month)

end 


\section{Calculate-Village-Score}

to calculate-village-score

if gov-policy $=$ True

;If gov-policy is True:

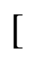

ask villages

[ ifelse village-score $>=582$

;If village's village-score is $>=0.582$ :

[ if random-float $1>.9$

;There is a $10 \%$ probability of:

[ set policy (policy * 1 + random-float 0.01 ) ] ]

;Increasing policy by \# btwn. 0 - 1\%

[ if random-float $1>.5$

;Otherwise, a 50\% probability of:

[ set policy (policy * $1+$ random-float 0.05 ) ] ] ] ;Increasing policy by \# btwn. 0 - 5\%

]

if equal-rights-policy $=$ True

;if equal-rights-policy is True:

[

ask villages

[ ifelse village-score $>=582$

;If village's village-score is $>=0.582$ :

[ if random-float $1>.9$

;There is a $10 \%$ probability of:

[ set $\operatorname{cacf}(\operatorname{cacf} * 1+$ random-float 0.01 ) ] ]

;Increasing policy by \# btwn. 0 - 1\%

[ if random-float $1>.5$

;Otherwise, a 50\% probability of:

[ set policy ( policy * $1+$ random-float 0.05 ) ] ] ] ;Increasing policy by \# btwn. 0 - 5\%

] 
set forest-percent ( ( ( count patches with

[ forest $=$ True ] ) / 8997 ) $* 100$ )

if random-float $100>$ forest-percent

[

ask villages

[ set forestneed

( forestneed $* 1+$ random-float 0.25 ) ]

]

ask villages

[

if random-float $100<$

( ( ( population - pop-original )

/ pop-original ) * 100 )

[ set forestneed forestneed $* .75+$ random-float 0.25 ]

]

ask villages

[

let nearest-neighbors other villages

let their-fn-scores

( mean [ forestneed ] of nearest-neighbors )
;Set forest-percent as:

;\% of forest relative to \% at Setup

;\# btwn. 0 - 100 is > forest-percent:

;Increase forestneed \# btwn. 0-25\%

;If \# between 0 - 100 is less than:

;\% of population growth

;Decrease forestneed \# btwn. 0 - 25\%

;Nearest-neighbors as other villages

;Set their-fn-scores as:

;Mean forestneed of neighbors 
ifelse their-fn-scores $>$ forestneed

[ let fn-difference ( their-fn-scores - forestneed )

if random-float .5 < mimic-neighbors

[ set forestneed forestneed +

random-float fn-difference ] ]

[ let fn-difference ( forestneed - their-fn-scores )

if random-float .5 < mimic-neighbors

[ set forestneed forestneed -

random-float fn-difference ] ]

]

ask villages

[

let nearest-cacf-neighbors other villages

let their-cacf-scores

( mean [ cacf ] of nearest-cacf-neighbors )

ifelse their-cacf-scores > cacf

[ let cacf-difference (their-cacf-scores - cacf )

if random-float .5 < mimic-neighbors

[ set cacf cacf +
;If their-fn-scores > forestneed:

;Diff: their-fn-scores \& forestneed

;If \# btwn. 0-0.5 < mimic-neighbors:

;Set forestneed forestneed +:

;\# btwn. 0-fn-difference

;Diff: their-fn-scores \& forestneed

;If \# btwn. 0-0.5 > mimic-neighbors:

;Set forestneed forestneed minus:

;\# btwn. 0-fn-difference
;Nearest-cacf-neighbors other villages

;Set their-cacf-scores as:

;Mean cacf of neighbors

;If their-cacf-scores > cacf:

;Find diff: their-cacf-scores \& cacf

;If \# between 0 - 0.5 < mimic-neighbors:

;Set cacf to own cacf plus: 
[ let cacf-difference ( cacf - their-cacf-scores ) ;Find diff: their-cacf-scores \& cacf if random-float $.5<$ mimic-neighbors $\quad$;If \# between 0 - $0.5<$ mimic-neighbors: [ set cacf cacf ;Set cacf to own cacf minus: random-float cacf-difference ] ] ;\# btwn. 0-cacf-difference ]

ask villages

[

let nearest-policy-neighbors other villages ;Set as other villages

let their-policy-scores ;Set their-policy-scores as: ( mean [ policy ] of nearest-policy-neighbors ) ;Mean policy of neighbors

ifelse their-policy-scores > policy ;If their-policy-scores > policy: [ let policy-difference ( their-policy-scores - policy ) ;Diff: their-policy-scores \& policy if random-float . $5<$ mimic-neighbors ;\# btwn. 0-0.5 < mimic-neighbors: [ set policy policy + ;Set policy to own policy plus: random-float policy-difference ] ] ;\# btwn. 0-policy-difference

[ let policy-difference ( policy - their-policy-scores ) ;Diff: their-policy-scores \& policy if random-float . $5<$ mimic-neighbors ;\# btwn. 0-0.5 < mimic-neighbors: [ set policy policy ;Set policy to own policy minus: 


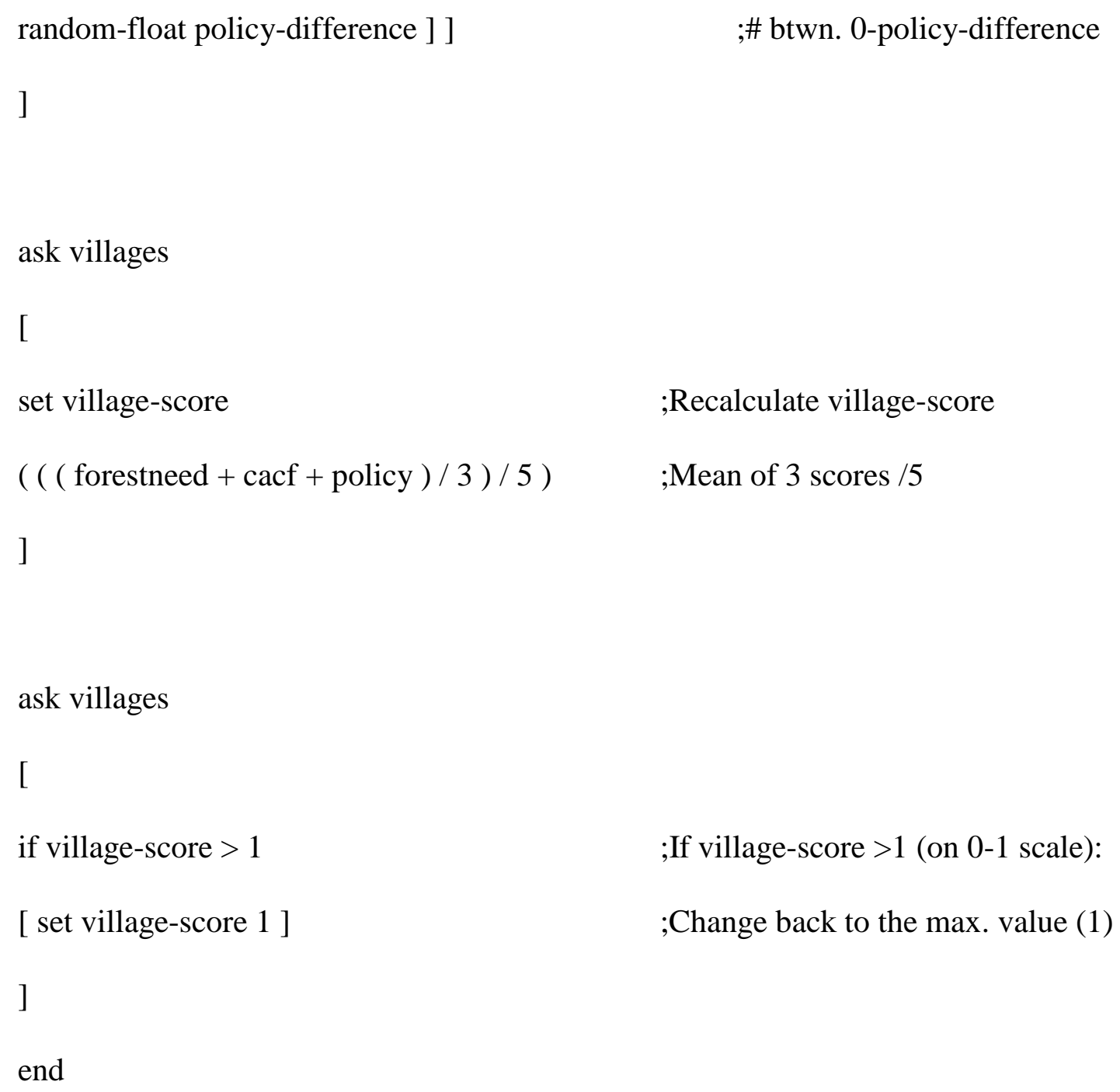

$((($ forestneed + cacf + policy $) / 3) / 5) \quad$;Mean of 3 scores $/ 5$

;\# btwn. 0-policy-difference

;Recalculate village-score

;If village-score >1 (on 0-1 scale):

;Change back to the max. value (1)

\section{Calculate-Support-For-Forests}

to calculate-support-for-forests

ask villages

[

ifelse village-score $>=.582$

[ set support-f? True set color blue ]

;If village-score is $>=0.582$ :

;Set support-f? true, change color to blue 
[ set support-f? False set color red ]

]

end
;Set support-f? false, change color to red

\section{$\underline{\text { Calculate-Patches-Conversions }}$}

to calculate-patches-conversions

set grow-a 0

;Reset local variable grow-a to zero

set grow-f 0

;Reset local variable grow-f to zero

;Ask Sauraha (Village 0):

ask village 0

\author{
;Ask Sauraha (Village 0):
}

[

ifelse support-f? $=$ True

;If suport-f? = true, than:

[ set grow-f ( grow-f + pop-patches ) ]

;Set grow-f to grow-f plus pop-patches

[ set grow-a ( grow-a + pop-patches ) ]

;Otherwise, grow-a to grow-a + pop-patches

]

ask village 1

;Ask Bachauli (Village 1):

[

ifelse support-f? = True

;If suport-f? = true, than:

[ set grow-f ( grow-f + pop-patches ) ]

;Set grow-f to grow-f plus pop-patches

[ set grow-a ( grow-a + pop-patches ) ]

;Otherwise, grow-a to grow-a + pop-patches

] 
ask village 2

[

ifelse support-f? = True

[ set grow-f ( grow-f + pop-patches ) ]

[ set grow-a ( grow-a + pop-patches ) ]

]

ask village 3

[

ifelse support-f? = True

[ set grow-f ( grow-f + pop-patches ) ]

[ set grow-a ( grow-a + pop-patches ) ]

]

ask village 4

[

ifelse support-f? = True

[ set grow-f ( grow-f + pop-patches ) ]

[ set grow-a ( grow-a + pop-patches ) ]

]

end
;Ask Jankauli (Village 2):

;If suport-f? = true, than:

;Set grow-f to grow-f plus pop-patches

;Otherwise, grow-a to grow-a + pop-patches

;Ask Jhuwani (Village 3):

;If suport-f? = true, than:

;Set grow-f to grow-f plus pop-patches

;Otherwise, grow-a to grow-a + pop-patches

;Ask Tarauli (Village 4):

;If suport-f? = true, than:

;Set grow-f to grow-f plus pop-patches

;Otherwise, grow-a to grow-a + pop-patches 


\section{Convert-Patches}

to convert-patches

$\begin{array}{ll}\text { let random-grow-f-patches n-of }(\text { grow-f }) & \text {;Random patches = to grow-f } \\ \text { patches with [ shrub = True } & \text {;Patches are shrub patches } \\ \text { and count neighbors with [ forest = True ] }>0 \text { ] } & \text {;Patches border }>=1 \text { forest patch }\end{array}$

ask random-grow-f-patches _ ;Ask these shrub patches:

[

set forest True $\quad$;Set forest to true

set shrub False $\quad$;Set shrub to false

]

let random-grow-a-patches n-of ( grow-a ) ;Random patches = to grow-a

patches with $[$ shrub $=$ True or forest $=$ True $\quad$;Patches are either shrub or forest

and count neighbors with $[$ agriculture $=$ True $]>\quad$;Patches border $>=1$ agriculture

0 ] patch

ask random-grow-a-patches ;Ask these shrub or forest patches:

[

set agriculture True — ;Set agriculture to true

set shrub False $\quad$;Set shrub to false

set forest False $\quad$;Set forest to false 
end

\section{Grow-Population}

to grow-population

ask villages $\quad$;Ask each village:

[

set population ( ( population ) * ;Set population as current population, plus:

$(1+($ population-growth-rate / 100$))$ ) ;Population growth rate from slider

set pop-patches ( round ( population / 1000 ;Set pop-patches as population /1,000

))

]

end

\section{Update-Patch-Color}

to update-patch-color

ask patches with [ forest $=$ True $] \quad$;If forest equals true (LULCC type is forest):

[ set pcolor 61 ]

;Change patch color to dark green

ask patches with [ agriculture $=$ True ] $\quad$;If agriculture equals true (LULCC type is ag.):

[ set pcolor 55 ]

;Change patch color to light green

ask patches with $[$ shrub $=$ True $] \quad$;If shrub equals true (LULCC type is shrub): 
[ set pcolor 34 ]

ask patches with [ river $=$ True ]

[ set pcolor 95 ]

end
;Change patch color to brown

;If river equals true (LULCC type is river):

;Change patch color to light blue 


\section{BIOGRAPHY OF THE AUTHOR}

Jared R. Stapp grew up in a small agricultural town in northern Utah, and because of that, has always had an intimate connection with the natural world. The nearest metropolitan hub was 80 miles away, so he spent his youth exploring the seemingly unlimited trails in the neighboring mountains, canyons, and deserts. Today, Jared finds a similar sense of exploration, inquisitiveness, and fulfillment from his academic pursuits. While in his undergraduate at Utah State University (USU), Jared was a laboratory technician for three years at the USDA Forage and Range Research Laboratory, a restoration ecology technician in USU's College of Natural Resources, completed an NSF-funded Research Experience for Undergraduates internship with the Smithsonian Environmental Research Center in Edgewater, Maryland, and was a research intern for five months with the Institute for Tropical Ecosystem Studies at the University of Puerto Rico. After completing his B.S. degree in Environmental Studies with a minor in Sustainable Systems in December, 2012, Jared migrated to Orono, Maine in the fall of 2013, where he had developed a great connection with his adviser Dr. Robert Lilieholm, who gave him the freedom to design his thesis work and expressed his interest in beginning a project in Nepal. Upon completion of his M.S. in the summer of 2015, Jared will leave New England to return to the West and begin a Ph.D. in Environmental Science, Policy, and Management at the University of California, Berkeley with the long-term goal of being a university professor, researcher, and mentor to students. He is a candidate for the Master of Science in Ecology and Environmental Science degree from the University of Maine in August 2015. 